Nevada

Environmental

Restoration

Project
DOE/NV-509

UC-700

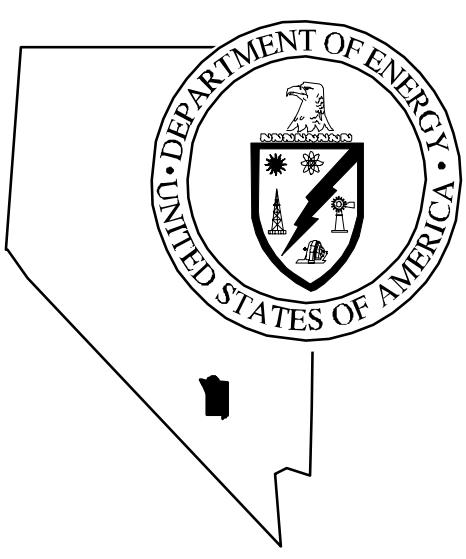

Corrective Action Decision Document for Corrective Action Unit 427:

Area 3 Septic Waste Systems 2 and 6, Tonopah Test Range, Nevada

Controlled Copy No.: 9

Revision No.:

June 1998

Approved for public release; further distribution is authorized.

Environmental Restoration

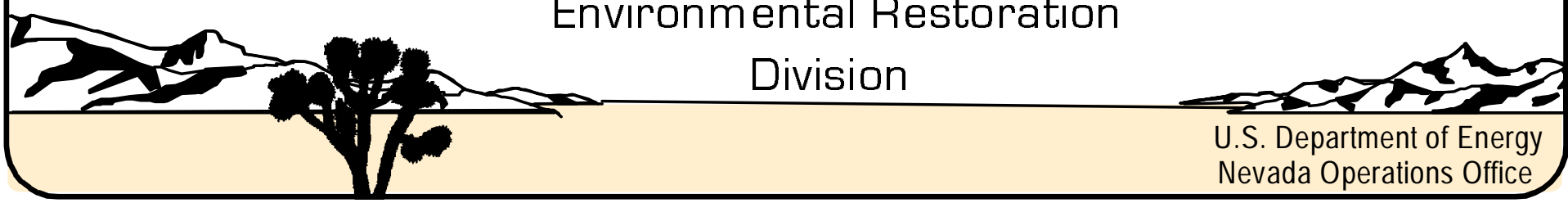


This report has been reproduced directly from the best available copy.

Available to DOE and DOE contractors from the Office of Scientific and Technical Information, P.O. Box 62, Oak Ridge, TN 37831; prices available from (423) 576-8401.

Available to the public from the National Technical Information Service, U.S. Department of Commerce, 5285 Port Royal Road, Springfield, VA 22161, telephone (703) 487-4650. 


\section{CORRECTIVE ACTION DECISION DOCUMENT FOR CORRECTIVE ACTION UNIT 427: AREA 3 SEPTIC WASTE SYSTEMS 2 AND 6, TONOPAH TEST RANGE, NEVADA}

DOE Nevada Operations Office

Las Vegas, Nevada

Controlled Copy No.:

Revision No.: 0

June 1998

Approved for public release; further distribution is authorized. 


\section{CORRECTIVE ACTION DECISION DOCUMENT \\ FOR CORRECTIVE ACTION UNIT 427: \\ AREA 3 SEPTIC WASTE SYSTEMS 2 AND 6, TONOPAH TEST RANGE, NEVADA}

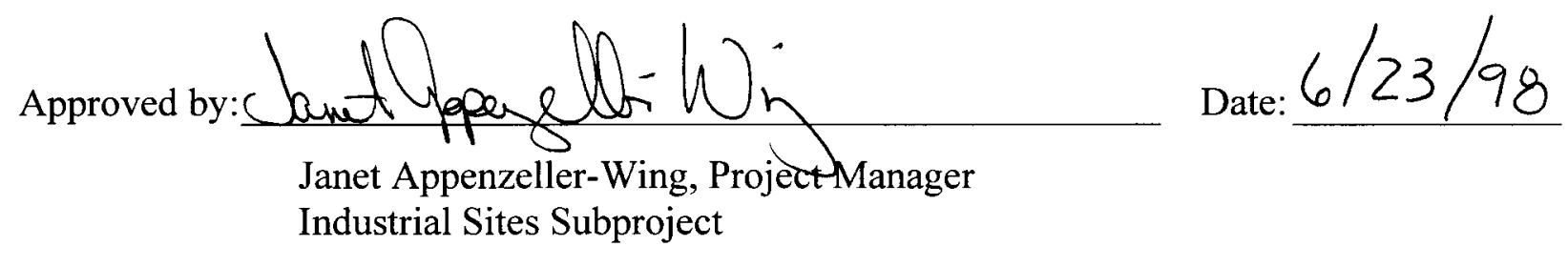

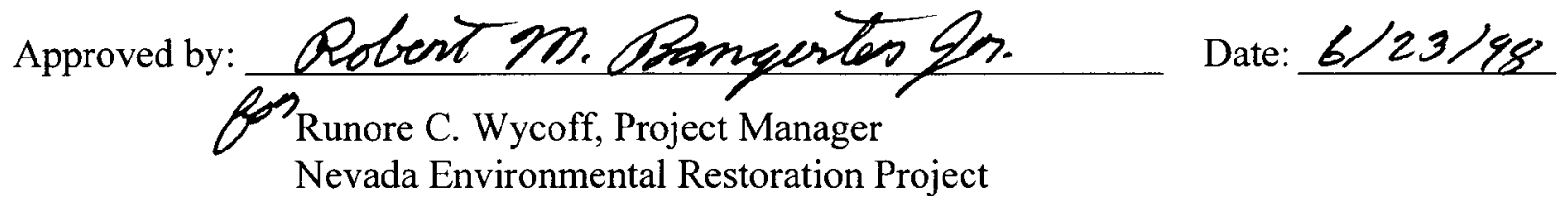




\section{Table of Contents}

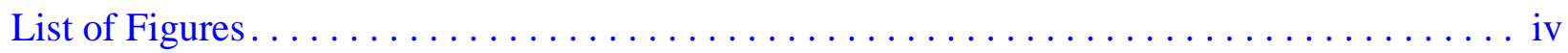

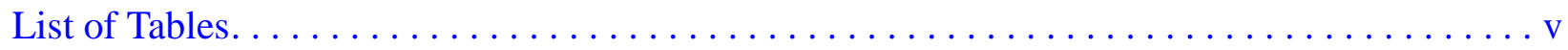

List of Acronyms and Abbreviations $\ldots \ldots \ldots \ldots \ldots \ldots \ldots \ldots \ldots \ldots \ldots \ldots \ldots \ldots$

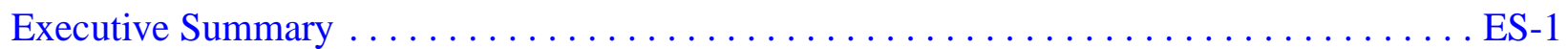

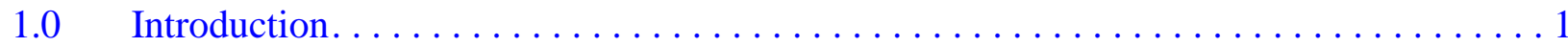

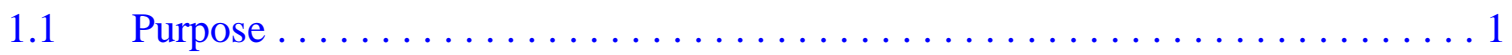

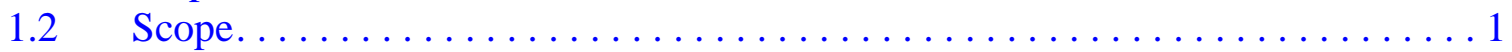

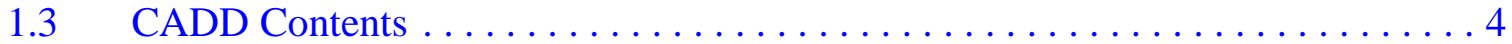

2.0 Corrective Action Investigation Summary $\ldots \ldots \ldots \ldots \ldots \ldots \ldots \ldots \ldots \ldots \ldots \ldots \ldots$

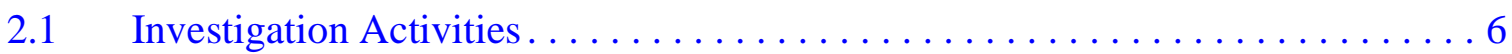

$2.2 \quad$ Results. . . . . . . . . . . . . . . . . . . . . .

$2.3 \quad$ Need for Corrective Action. . . . . . . . . . . . . . . . . . . 8

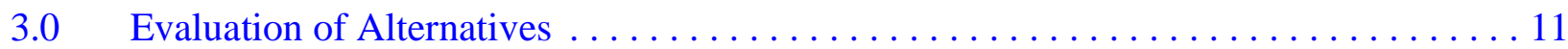

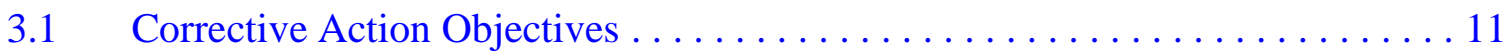

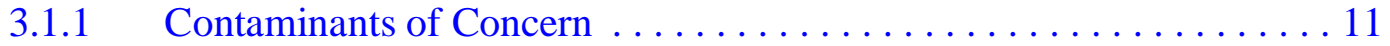

3.1.2 Potential Exposure Pathways. . . . . . . . . . . . . . . . . . . . 11

$3.2 \quad$ Screening Criteria . . . . . . . . . . . . . . . . . . . . . . 12

3.2.1 Corrective Action Standards . . . . . . . . . . . . . . . . . . 12

3.2.2 Remedy Selection Decision Factors . . . . . . . . . . . . . . . 14

3.3 Development of Corrective Action Alternatives . . . . . . . . . . . . . . . 15

3.3.1 Alternative 1 - No Further Action . . . . . . . . . . . . . . . . 18

3.3.2 Alternative 2 - Closure of Septic Tank 33-5

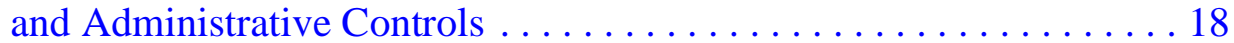

3.3.3 Alternative 3 - Closure of Septic Tank 33-5, Excavation,

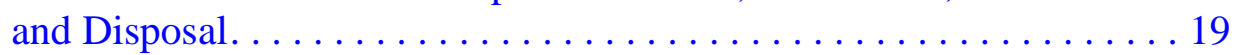

3.4 Evaluation and Comparison of Alternatives................ 20

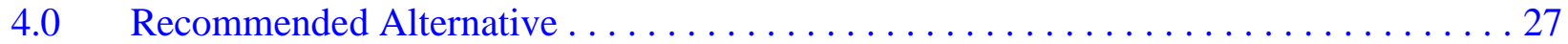

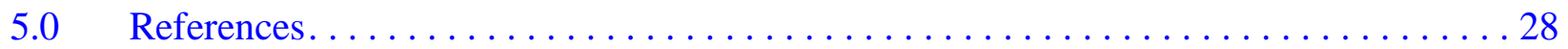

Appendix A - Corrective Action Investigation Report for CAU 427: Area 3 Septic Waste Systems 2 and 6, Tonopah Test Range, Nevada

A.1.0 Introduction. . . . . . . . . . . . . . . . . . . . . . . . . . . . A-1

A.1.1 Project Objectives . ........................... A-1

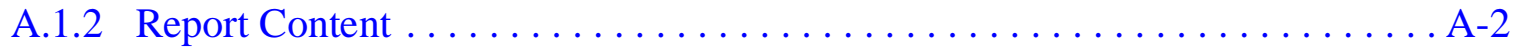




\section{Table of Contents (Continued)}

A.2.0 Field Investigation and Sampling Activities. . . . . . . . . . . . . A-4

A.2.1 Site Description and Conditions . . . . . . . . . . . . . . A-4

A.2.2 Past Geophysical Surveys. . . . . . . . . . . . . . . . . . . A-5

A.2.3 Sampling Logistics . . . . . . . . . . . . . . . . . . . . A -5

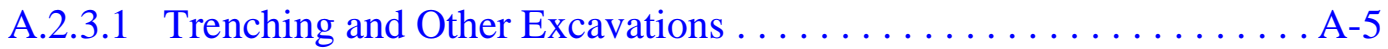

A.2.3.2 Drilling. ......................

A.2.3.3 Field Screening . . . . . . . . . . . . . . . A-7

A.2.3.4 Sample Collection . . . . . . . . . . . . . . . . . . . . A-9

A.2.3.5 Pre-1965 Leachfield (SWS 6) . . . . . . . . . . . . . . . A-10

A.2.3.6 1965-1975 Leachfield (SWS 2) . . . . . . . . . . . . . . . . . A-11

A.2.3.7 Post-1975 Leachfield (SWS 2) . . . . . . . . . . . . . . . A-12

A.2.3.8 Septic Tanks............................. A-13

A.2.3.9 Septic Tank 33-5 Samples . . . . . . . . . . . . . . . . . A-14

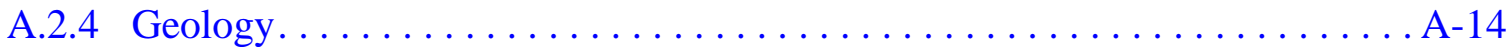

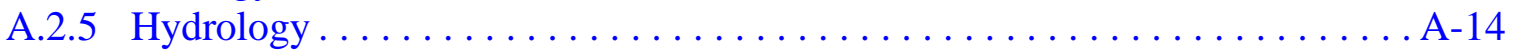

A.3.0 Investigation Results. . . . . . . . . . . . . . . . . . . . . . A-15

A.3.1 Total Volatile Organic Compound Analytical Results . . . . . . . . . . . . . A-22

A.3.2 Total Semivolatile Organic Compound Analytical Results . . . . . . . . . . . A-25

A.3.3 Total Petroleum Hydrocarbon Results . . . . . . . . . . . . . . A

A.3.4 Total RCRA Metals Results . . . . . . . . . . . . . . . . . . A

A.3.5 PCB Analytical Results . . . . . . . . . . . . . . . . . A-27

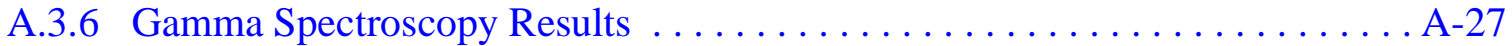

A.3.7 Septic Tank 33-5 Samples ... . . . . . . . . . . . . . . . . . A-33

A.3.8 Geotechnical Results. . . . . . . . . . . . . . . . . A-33

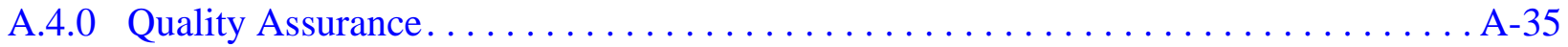

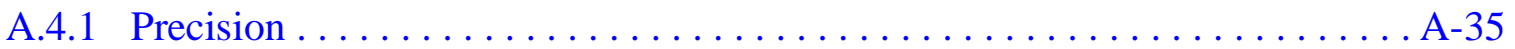

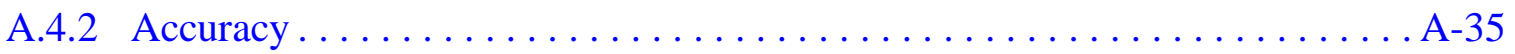

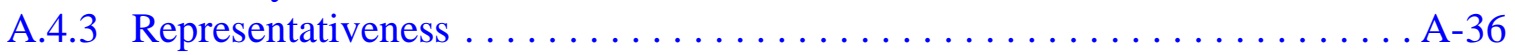

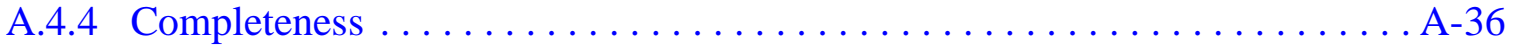

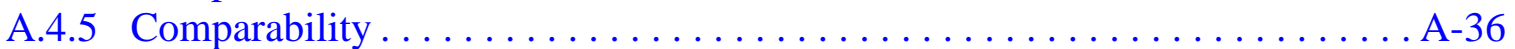

A.4.6 Tier I and Tier II Data Evaluations . . . . . . . . . . . . . . A A-37

A.4.6.1 Tier I Evaluation $\ldots \ldots \ldots \ldots \ldots \ldots \ldots \ldots \ldots \ldots \ldots \ldots \ldots \ldots \ldots \ldots \ldots \ldots$

A.4.6.2 Tier II Evaluation. . . . . . . . . . . . . . . . . . $\ldots \ldots$

A.4.6.3 Tier III . . . . . . . . . . . . . . . . . . A-39

A.4.7 Quality Control Samples. . . . . . . . . . . . . . . . . . . . . A-39

A.4.7.1 Field Quality Control Samples . . . . . . . . . . . . . . . A-40

A.4.7.2 Laboratory Quality Control Samples. . . . . . . . . . . . . . . . . . A-42

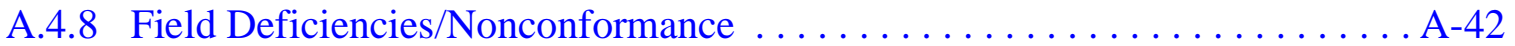




\section{Table of Contents (Continued)}

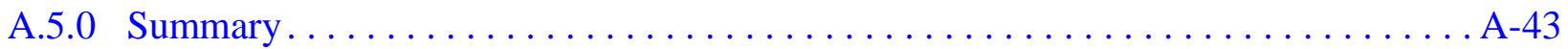

A.6.0 References....................................... A-44

Appendix B - Soil Boring Logs

Appendix C - Cost Estimates

Appendix D - Response to NDEP Comments 


\section{List of Figures}

Number

1-1 Tonopah Test Range Location Map $\ldots \ldots \ldots \ldots \ldots \ldots \ldots \ldots \ldots \ldots \ldots \ldots \ldots$

1-2 Location of Area 3 Tonopah Test Range $\ldots \ldots \ldots \ldots \ldots \ldots \ldots \ldots$

2-1 CAU 427 Tonopah Test Range Septic Waste Systems 2 and 6 Utilities - Active and Abandoned ............................. 10

A.2-1 CAU 427 Tonopah Test Range Septic Waste Systems 2 and 6 Attribute Composite Map (DQO) . . . . . . . . . . . . . . . . . . . A-6

A.2-2 CAU 427 Tonopah Test Range Septic Waste Systems 2 and 6 Collection Point Map ................................. A-8 


\section{List of Tables}

Number

Title

Page

ES-1 Locations of Contaminants of Concern . . . . . . . . . . . . . . . . ES-2

3-1 Detailed Evaluation of Alternatives...................... 21

3-2 Comparative Evaluation of Alternatives .................... 25

A.3-1 Samples Collected During the Area 3 SWS $2 \& 6$

Corrective Action Investigation Activities . ................. A-15

A.3-2 Laboratory Analytical Methods Used for Area 3

SWS $2 \& 6$ Investigation Samples..................... A-22

A.3-3 Soil Sample Results for Total Volatile Organic Compounds Detected Above Minimum Reporting Limits, Area 3 SWS 2 \& 6, TTR .......... A-23

A.3-4 Summary of Total Petroleum Hydrocarbon Results Detected Above Minimum Reporting Limit for Waste Oil . . . . . . . . . . . . . A-26

A.3-5 Soil Sample Results for Total RCRA Metal Constituents Detected Above Minimum Reporting Limits, Area 3 SWS $2 \&$, TTR ......... A-28

A.3-6 Sample Results for Constituents Detected in Septic Tank 33-5, Area 3 SWS $2 \& 6$, TTR . . . . . . . . . . . . . . . . . 34 


\section{List of Acronyms and Abbreviations}

\begin{tabular}{|c|c|}
\hline bgs & Below ground surface \\
\hline CADD & Corrective Action Decision Document \\
\hline CAIP & Corrective Action Investigation Plan \\
\hline CAS & Corrective Action Site \\
\hline CAU & Corrective Action Unit \\
\hline CFR & Code of Federal Regulations \\
\hline CLP & Contract Laboratory Program \\
\hline $\mathrm{cm}$ & Centimeter(s) \\
\hline $\mathrm{cm} / \mathrm{sec}$ & Centimeter(s) per second \\
\hline $\mathrm{COA}$ & Certificates of Analysis \\
\hline $\mathrm{COC}$ & Contaminant(s) of concern \\
\hline COPCs & Contaminants of potential concern \\
\hline DQO & Data Quality Objective(s) \\
\hline $\mathrm{DOE} / \mathrm{NV}$ & U.S. Department of Energy, Nevada Operations Office \\
\hline EDT & Electronic data transfer \\
\hline EPA & U.S. Environmental Protection Agency \\
\hline FFACO & Federal Facility Agreement and Consent Order \\
\hline $\mathrm{ft}$ & Foot (feet) \\
\hline $\mathrm{ft}^{2}$ & Square foot (feet) \\
\hline $\mathrm{ICP}$ & Inductively coupled plasma \\
\hline IDW & Investigation-derived waste \\
\hline in. & $\operatorname{Inch}(\mathrm{es})$ \\
\hline IT & IT Corporation \\
\hline
\end{tabular}




\section{List of Acronyms and Abbreviations (Continued)}

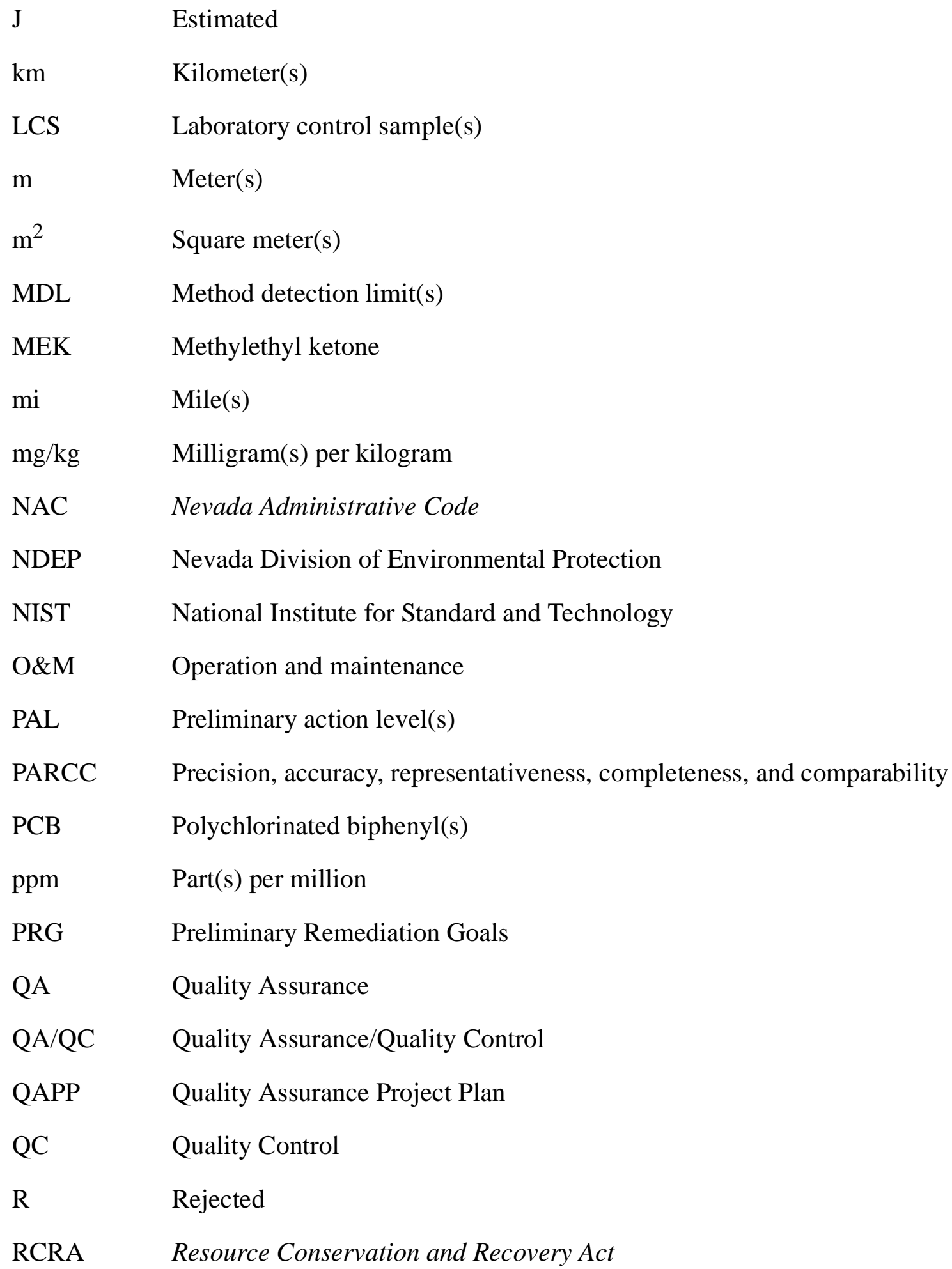




\section{List of Acronyms and Abbreviations (Continued)}

$\begin{array}{ll}\text { RPD } & \text { Relative percent difference } \\ \text { SDG } & \text { Same delivery group } \\ \text { SNL } & \text { Sandia National Laboratories } \\ \text { SVOC } & \text { Semivolatile organic compound(s) } \\ \text { SWS } & \text { Septic Waste System(s) } \\ \text { TPH } & \text { Total petroleum hydrocarbon(s) } \\ \text { TTR } & \text { Tonopah Test Range } \\ \text { U } & \text { Undetected } \\ \text { VOC } & \text { Volatile organic compound(s) } \\ \text { yd }{ }^{3} & \text { Cubic yard(s) } \\ \mu \mathrm{g} / \mathrm{L} & \text { Microgram(s) per liter } \\ \mu \mathrm{gg} / \mathrm{kg} & \text { Microgram(s) per kilogram } \\ \% \mathrm{R} & \text { Percent recovery }\end{array}$




\section{Executive Summary}

This Corrective Action Decision Document has been prepared for the Area 3 Septic Waste Systems 2 and 6 (Corrective Action Unit 427) in accordance with the Federal Facility Agreement and Consent Order of 1996 (FFACO, 1996).

Corrective Action Unit 427 is located at the Tonopah Test Range, Nevada, and is comprised of the following Corrective Action Sites, each an individual septic waste system (DOE/NV, 1996a):

- $\quad$ Septic Waste System 2 is Corrective Action Site Number 03-05-002-SW02.

- Septic Waste System 6 is Corrective Action Site Number 03-05-002-SW06.

The purpose of this Corrective Action Decision Document is to identify and provide a rationale for the selection of a recommended corrective action alternative for each Corrective Action Site.

The scope of this Correction Action Decision Document consists of the following tasks:

- Develop corrective action objectives.

- Identify corrective action alternative screening criteria.

- Develop corrective action alternatives.

- Perform detailed and comparative evaluations of the corrective action alternatives in relation to the corrective action objectives and screening criteria.

- Recommend and justify a preferred corrective action alternative for each CAS.

From November 1997 through January 1998, a corrective action investigation was performed as set forth in the Corrective Action Investigation Plan for Corrective Action Unit No. 427: Area 3 Septic Waste System Numbers 2 and 6, Tonopah Test Range, Nevada (DOE/NV, 1997b). Details can be found in Appendix A of this document. The results indicated that contamination is present in some portions of the CAU and not in others as described in Table ES-1 and shown in Figure A.2-2 of Appendix A.

Based on the potential exposure pathways, the following corrective action objectives have been identified for Corrective Action Unit 427:

- Prevent or mitigate human exposure to subsurface soils containing TPH at concentrations greater than 100 milligrams per kilogram (NAC, 1996b).

- Close Septic Tank 33-5 in accordance with Nevada Administrative Code 459 (NAC, 1996c).

- Prevent adverse impacts to groundwater quality. 
Table ES-1

Locations of Contaminants of Concern

\begin{tabular}{||l|c|c||}
\hline \multirow{2}{*}{ Septic Waste System Component } & \multicolumn{2}{c||}{ Investigation Results } \\
\cline { 2 - 4 } & $\begin{array}{c}\text { No Contaminants of } \\
\text { Concern Present }\end{array}$ & $\begin{array}{c}\text { Contaminants of } \\
\text { Concern Present }\end{array}$ \\
\hline \hline Septic Waste System 6: Pre-1965 Leachfield & $\mathrm{X}$ & \\
\hline $\begin{array}{l}\text { Septic Waste System 2: Distal End of 1965-1975 } \\
\text { Leachfield; Southern Leg of Post 1975 Leachfield; } \\
\text { Outfall ends of Tanks 33-6 and 33-12 }\end{array}$ & $\mathrm{X}$ & \\
\hline $\begin{array}{l}\text { Septic Waste System 2: Leachbeds and Drainage } \\
\text { Ends of the Central and Northern Legs and the } \\
\text { Distribution Box Associated with Post-1975 } \\
\text { Leachfield }\end{array}$ & & \\
\hline $\begin{array}{l}\text { Septic Waste System 2: Fork Associated with } \\
\text { 1965-1975 Leachfield }\end{array}$ & & \\
\hline $\begin{array}{l}\text { Septic Waste System 2: Outfall End of Septic } \\
\text { Tank 33-4 }\end{array}$ & & \\
\hline
\end{tabular}

Based on the review of existing data, future land use, and current operations at the Tonopah Test Range, the following alternatives were developed for consideration at the Area 3 Septic Waste Systems 2 and 6:

- Alternative 1 - No Further Action

- Alternative 2 - Closure of Septic Tank 33-5 and Administrative Controls

- Alternative 3 - Closure of Septic Tank 33-5, Excavation, and Disposal

The corrective action alternatives were evaluated based on four general corrective action standards and five remedy selection decision factors. Based on the results of this evaluation, the preferred alternative for Corrective Action Unit 427 is Alternative 2, Closure of Septic Tank 33-5 and Administrative Controls.

The preferred corrective action alternative was evaluated on technical merit, focusing on performance, reliability, feasibility, and safety. The alternative was judged to meet all requirements for the technical components evaluated. The alternative meets all applicable state and federal regulations for closure of the site and will reduce potential future exposure pathways to the contaminated soils. 
During corrective action implementation, this alternative will present minimal potential threat to site workers who come in contact with the waste. However, procedures will be developed and implemented to ensure worker health and safety. 


\subsection{Introduction}

This Corrective Action Decision Document (CADD) has been prepared for Corrective Action Unit (CAU) 427, Area 3 Septic Waste Systems 2 and 6, in accordance with the Federal Facility Agreement and Consent Order (FFACO) of 1996 that was agreed to by the U.S. Department of Energy, Nevada Operations Office (DOE/NV); the Nevada Division of Environmental Protection (NDEP); and the U.S. Department of Defense (FFACO, 1996). The CADD provides or references the specific information necessary to recommend corrective actions for the Corrective Action Sites (CAS) within CAU 427. Septic Waste Systems 2 and 6 (SWS 2\&6) are associated with CAS Numbers 03-05-002-SW02 and 03-05-002-SW06, respectively (Figure A.2-1 in Appendix A).

Corrective Action Unit 427 is located at the Tonopah Test Range (TTR), Nevada. The TTR, included in the Nellis Air Force Range complex, is approximately 255 kilometers (km) (140 miles[mi]) northwest of Las Vegas, Nevada (Figures 1-1 and 1-2).

\subsection{Purpose}

This CADD identifies and provides a rationale for the selection of a recommended corrective action alternative for the CAU. The need for these alternatives is based on process knowledge and the results of investigative activities conducted in accordance with the Corrective Action Investigation Plan for Corrective Action Unit No. 427: Area 3 Septic Waste System Numbers 2 and 6, Tonopah Test Range, Nevada (DOE/NV, 1997b).

\subsection{Scope}

The scope of this CADD consists of the following tasks:

- Develop corrective action objectives.

- Identify corrective action alternative screening criteria.

- Develop corrective action alternatives. 


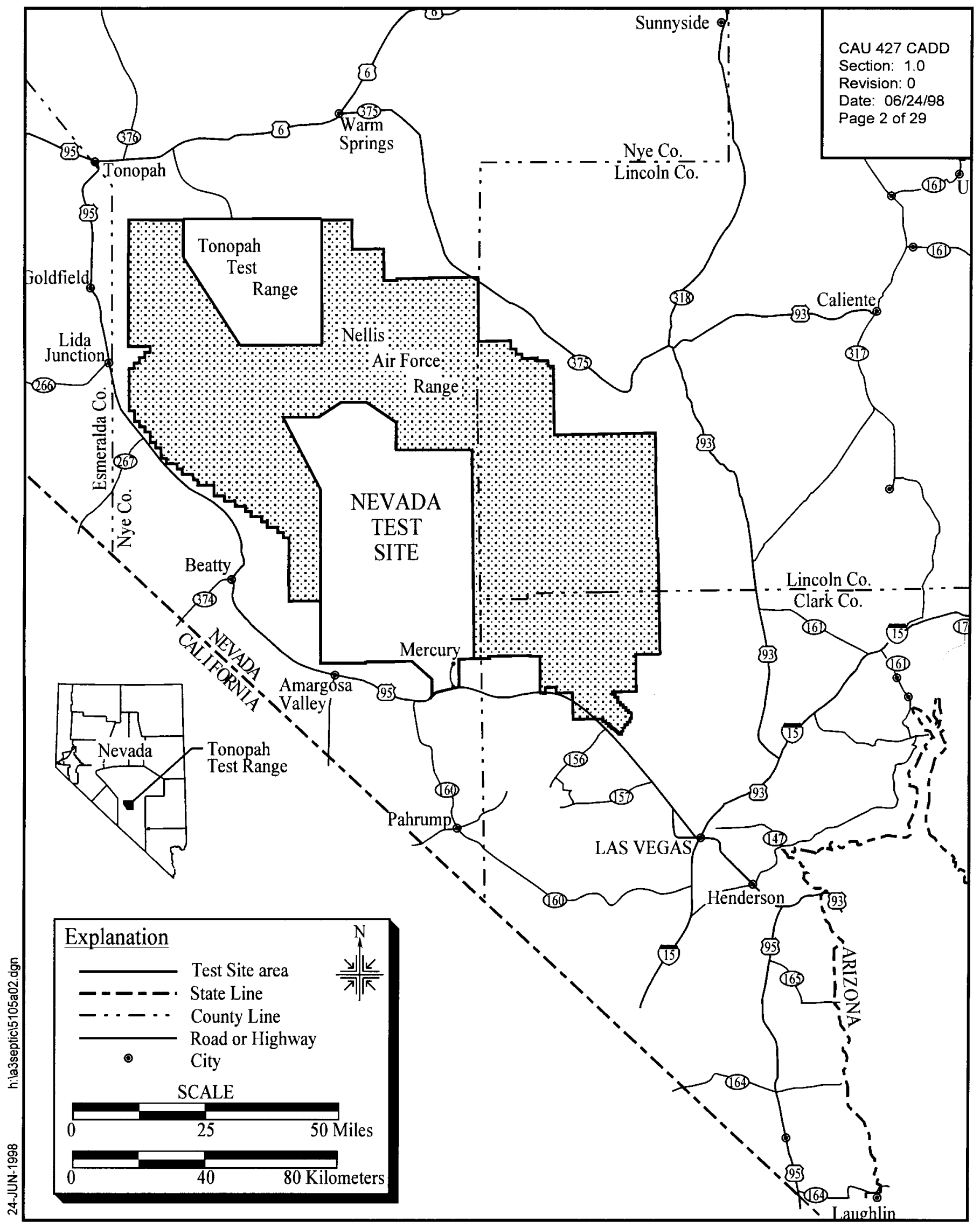

Figure 1-1

Tonopah Test Range Location Map 


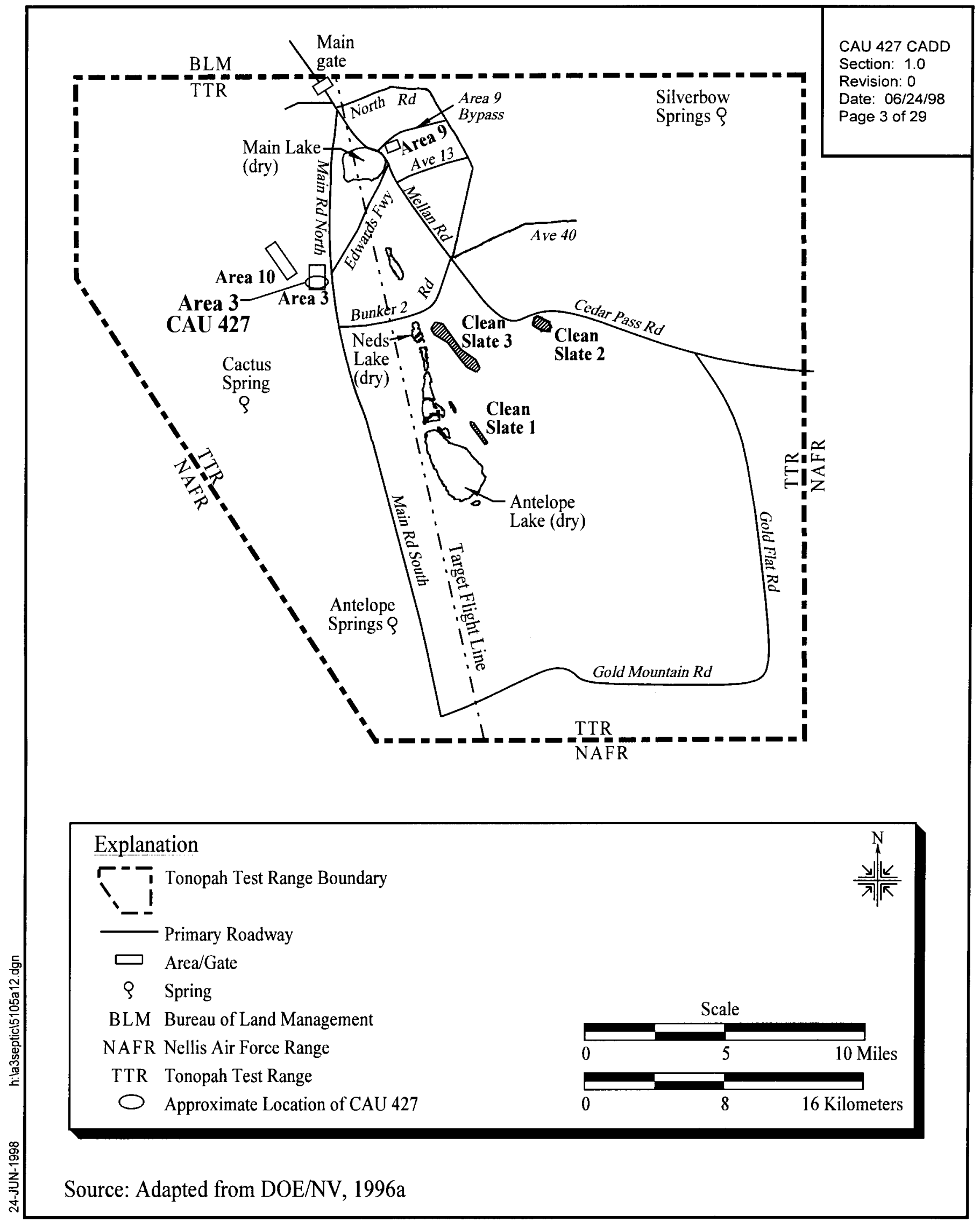

Figure 1-2

Location of Area 3 Tonopah Test Range 
- Perform detailed and comparative evaluations of corrective action alternatives in relation to corrective action objectives and screening criteria.

- $\quad$ Recommend and justify a preferred corrective action alternative for the CAU.

\section{$1.3 \quad C A D D$ Contents}

This CADD is divided into the following sections:

Section 1.0 - Introduction: summarizes the purpose, scope, and contents of this CADD

Section 2.0 - Corrective Action Investigation Summary: summarizes the investigation field activities, the results of the investigation, and the need for corrective action

Section 3.0 - Evaluation of Alternatives: documents steps taken to determine a preferred corrective action alternative

Section 4.0 - Recommended Alternative: presents the preferred corrective action alternative and the rationale for its selection based on the corrective action objectives and alternative screening criteria

Section 5.0 - References: provides a list of all referenced documents

Appendix A: Corrective Action Investigation Report for CAU 427: Area 3 Septic Waste Systems 2 and 6, TTR

Appendix B: Soil Boring Logs

Appendix C: Cost Estimates

Appendix D: Nevada Environmental Restoration Project Document Review Sheet

All work was performed in accordance with the following documents:

- Corrective Action Investigation Plan for Corrective Action Unit No. 427: Area 3 Septic Waste System Numbers 2 and 6, Tonopah Test Range, Nevada (DOE/NV, 1997b)

- Industrial Sites Quality Assurance Project Plan (DOE/NV, 1996c)

- Corrective Action Unit Work Plan, Tonopah Test Range, Nevada (DOE/NV, 1996a) 
- FFACO (FFACO, 1996)

- Project Management Plan (DOE/NV, 1994) 


\subsection{Corrective Action Investigation Summary}

The following sections describe and summarize the results of the investigation activities conducted at CAU 427. For detailed investigation results, please refer to Appendix A.

\section{$2.1 \quad$ Investigation Activities}

From November 1997 through January 1998, a corrective action investigation was performed that consisted of activities as set forth in the Corrective Action Investigation Plan (CAIP)

(DOE/NV, 1997b). The purpose of the investigation was to complete the following tasks:

- Identify the presence and nature of possible contaminant migration from the leachfields and associated wastewater collection systems.

- Determine the vertical and lateral extent of possible contaminant migration.

- Provide sufficient information and sample analytical data from which corrective action alternatives may be developed and evaluated in the CADD for the site.

- Obtain sufficient sample analytical data for management of investigation-derived waste (IDW).

The above tasks were accomplished in a three-phase investigation. The investigation activities conducted under each phase are summarized below:

\section{Phase I}

- Excavated ten trenches to define five inactive leachfields. Three were defined and evidence of the other two could not be found.

- Collected soil samples from two horizons within the trenches. The upper sampling horizon was at 0.3 meters $(\mathrm{m})$ (1 foot [ft]) above the leachbed basement. The lower sampling horizon was at $0.8 \mathrm{~m}(2.5 \mathrm{ft})$ beneath the leachbed basement. Soil samples were also obtained at the distribution boxes or forks of the three discovered leachfields.

- Located three of four septic tanks and sampled the soil at the outfall ends of the discovered septic tanks. The fourth tank was not found.

- Conducted pipeline video surveys to map the collection system network 


\section{Phase II}

- Evaluated sample analytical results from Phase I to guide drilling conducted in Phase III and to assist with waste management decisions

- Backfilled the trenches with clean spoils material

\section{Phase III}

- Drilled twenty-one soil borings to obtain subsurface soil samples at select locations based upon analytical results evaluated in Phase II

Continuous field-screening of excavated soil was conducted using headspace analysis for volatile organic compounds (VOCs), colorimetric testing for total petroleum hydrocarbons (TPH), and radiological screening for alpha and beta emitters. Soil samples were analyzed for total VOCs, total semivolatile organic compounds (SVOCs), total Resource Conservation and Recovery Act (RCRA) metals, TPH as diesel/waste oil, TPH as gasoline, polychlorinated biphenyls (PCB), and gamma-emitting radionuclides. Geotechnical samples were collected from in situ soil beneath the distribution box or fork for each leachfield and analyzed for initial moisture content, dry bulk density, calculated porosity, saturated/unsaturated hydraulic conductivity, particle size distribution, and water-release curve.

In addition, historical documents, interviews, and process knowledge assisted the potential contaminant identification process at each of the septic waste systems (see Appendix A).

\subsection{Results}

The corrective action investigation results indicated the following:

- All VOCs were below the preliminary action levels (PALs) (see Table A.3-3) outlined in the CAIP (DOE/NV, 1997b).

- All SVOCs were below the PALs (see Section A.3.2) outlined in the CAIP (DOE/NV, 1997b). Pyrene was detected in a sample that also had a detectable level of TPH as waste oil.

- Fifteen of the 120 soil samples contained TPH as waste oil at concentrations above the NDEP-established action level of 100 milligrams/kilogram (mg/kg) (see Table A.3-4). These concentrations are associated with the northern and central distribution lines and the 
distribution box of the Post-1975 Leachfield, the proximal end of the 1965-1975 Leachfield, and the outfall end of Septic Tank 33-4.

- Reported levels for all total RCRA metal samples (arsenic, barium, cadmium, chromium, lead, mercury, selenium, and silver) were within the PALs (see Table A.3-5) established in the CAIP (DOE/NV, 1997b) except for arsenic. All but two of the arsenic results were consistent with naturally occurring background levels as established in the TTR Area 3 CAU 424 corrective action investigation (DOE/NV, 1998a). The maximum concentration of $25.2 \mathrm{mg} / \mathrm{kg}$ was detected at $4.4 \mathrm{~m}(14.5 \mathrm{ft})$ in an area where fill material had been placed and is not believed to be associated with contamination.

- No PCBs were detected.

- Radiological results are within PALs as established in the CAIP (DOE/NV, 1997b) with the exception of three Potassium- 40 results. These samples were reanalyzed and found to be within PALs.

- Septic Tanks 33-4 and 33-5 were found to be inactive. Although inactive, Septic Tank 33-5 contained septage. Soil samples, numbers TTR000931 and TTR000933, were obtained from the outfall end of Septic Tank 33-5, and their associated analytical results did not indicate a release had occurred. Samples TTR-335-1 and TTR-335-2 were obtained from within Septic Tank 33-5. The results of these samples indicated the presence of TPH, VOCs, and pesticides at low levels (below PALs) (see Table A3-6). Septic Tank 33-6 was found to be active and in line with the SNL consolidated system.

Details of the methods used and results found during the investigation are presented in Appendix A. Based on these results, the nature and extent of contaminants of concern (COCs) at CAU 427 has been adequately identified.

\subsection{Need for Corrective Action}

Analytes detected during the corrective action investigation were evaluated against PALs to determine potential COCs for CAU 427. The COCs are those analytes detected at levels above PALs. This evaluation identified TPH as waste oil as the only contaminant above applicable regulatory limits (or PALs) and/or naturally occurring background levels as outlined in the CAIP (DOE/NV, 1997b). Therefore, an evaluation of possible remedial alternatives is required for this site to ensure worker, public, and environmental protection against potential exposure to the TPH contamination in accordance with Nevada Administrative Code (NAC) 445A (NAC, 1996b). 
Total petroleum hydrocarbons were detected above the $100 \mathrm{mg} / \mathrm{kg}$ PAL (NAC, 1996b) in soil samples taken from the leachbeds, drainage ends, and distribution box associated with the Post-1975 Leachfield (SWS 2); the fork associated with the 1965-1975 Leachfield (SWS 2); and the outfall end of Septic Tank 33-4 (SWS 2). The maximum detected concentration of 2,900 mg/kg was obtained at Septic Tank 33-4 at a depth of $1.5 \mathrm{~m}(5.0 \mathrm{ft})$. The distal end of the northern most leachline of the Post-1975 Leachfield produced the deepest concentration of waste oil above $100 \mathrm{mg} / \mathrm{kg}$ at $8.4 \mathrm{~m}$ $(27.5 \mathrm{ft})$.

The samples taken from within Septic Tank 33-5 indicated the presence of listed hazardous waste. As a result, Septic Tank 33-5 must be closed in accordance with NAC 459.9921 through 459.999 (NAC, 1996c), inclusive, and the Code of Federal Regulations (CFR) Title 40, Parts 280.60 through 280.74 (CFR, 1996), inclusive, and therefore, does not fall under Department of Human Resources, Health Division regulations. These regulations stipulate that all liquids and accumulated sludges must be removed from the tank. The tank must then be removed for disposal or filled with an inert solid material. The results of samples TTR-335-1 and TTR-335-2 can be used to guide waste management determinations.

Specific characteristics which may constrain remedial actions include underground utilities in the vicinity of the CAU (Figure 2-1) which could interfere with excavation or other corrective action activities.

Investigation activities did not indicate the presence of COCs above PALs at the Pre-1965 Leachfield (SWS 6); the distal end of the 1965-1975 Leachfield, the southern leg of the Post 1975 Leachfield, and the outfall ends of Tanks 33-6 and 33-12 (SWS 2) (Figure A.2-1). Therefore, no corrective actions are necessary at these portions of CAU 427 , and they will not be discussed further in this report. 


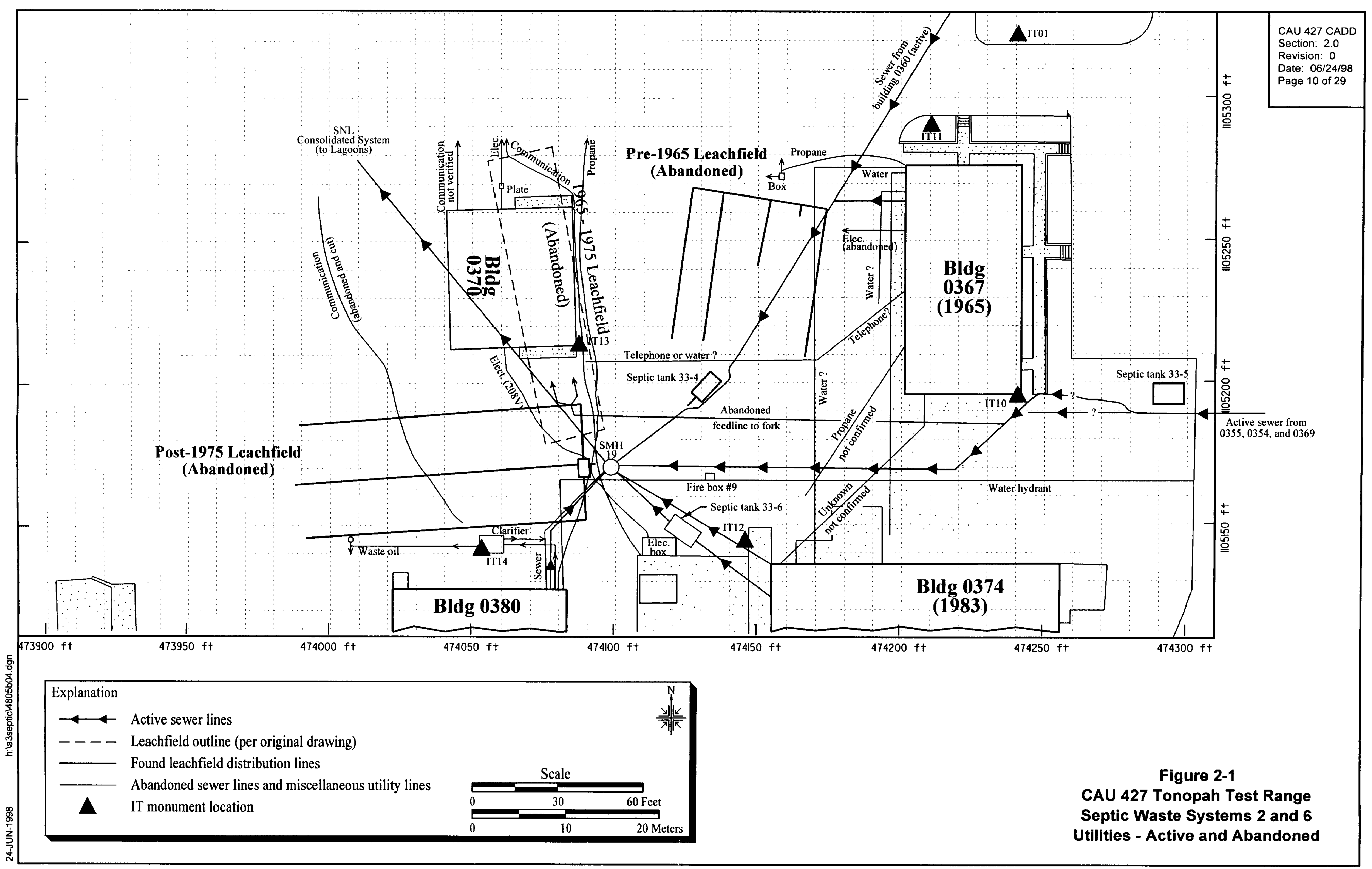




\subsection{Evaluation of Alternatives}

The purpose of this section is to present the corrective action objectives for CAU 427, describe the general standards and decision factors used to screen the corrective action alternatives, and develop and evaluate a set of corrective action alternatives that could be used to meet the corrective action objectives.

\subsection{Corrective Action Objectives}

The corrective action objectives are media-specific goals for protecting human health and the environment. Based on the potential exposure pathways (see Section 3.1.2), the following corrective action objectives have been identified for CAU 427 :

- Prevent or mitigate human exposure to subsurface soils containing TPH at concentrations greater than $100 \mathrm{mg} / \mathrm{kg}$ (NAC, 1996b).

- $\quad$ Close Septic Tank 33-5 in accordance with NAC 459 (NAC, 1996c).

- Prevent adverse impacts to groundwater quality.

\subsubsection{Contaminants of Concern}

Contaminants of potential concern (COPCs) were determined in the Data Quality Objective (DQO) process as listed in the CAIP (DOE/NV, 1997b). Analytical results obtained from the corrective action investigation were evaluated to determine which of those COPCs were detected above PALs, and should therefore, now be considered COCs for CAU 427. Only TPH as waste oil was detected at concentrations above PALs (Table A-3.4 of Appendix A). No other COCs were identified.

\subsubsection{Potential Exposure Pathways}

As part of the CAIP (DOE/NV, 1997b), a conceptual model for CAU 427 was developed which identified the potential exposure mechanism as excavation of contaminated material by site workers. This implies a potential exposure pathway through ingestion of soil under industrial scenarios. This pathway includes inhalation of vapors and dermal contact. Site workers could potentially be exposed to contaminated soil during excavation activities associated with underground utility maintenance and/or construction. Groundwater at the site is estimated to be 110 to $120 \mathrm{~m} \mathrm{(360} \mathrm{to} 390 \mathrm{ft}$ ) below 
ground surface (bgs). In addition, site conditions (i.e., relatively low concentrations of COCs, negative water balance, etc.) do not provide a driver for COCs to migrate to the water table. Therefore, the only potential exposure pathway would be through intrusive activities.

\subsection{Screening Criteria}

The screening criteria used to evaluate and select the preferred corrective action alternatives are identified in the U.S. Environmental Protection Agency (EPA) Guidance on Resource Conservation and Recovery Act Corrective Action Decision Documents (EPA, 1991) and the Final Resource Conservation and Recovery Act Corrective Action Plan (EPA, 1994).

Corrective action alternatives will be evaluated based on four general corrective action standards and five remedy selection decision factors. All corrective action alternatives must meet the general standards to be selected for evaluation using the remedy selection decision factors.

The general corrective action standards are:

- Protection of human health and the environment

- Compliance with media cleanup standards

- Control the source(s) of the release

- Comply with applicable federal, state, and local standards for waste management

The remedy selection decision factors are:

- Short-term reliability and effectiveness

- Reduction of toxicity, mobility, and/or volume

- Long-term reliability and effectiveness

- Feasibility

- Cost

\subsubsection{Corrective Action Standards}

The following text describes the corrective action standards used to evaluate the corrective action alternatives:

\section{Protection of Human Health and the Environment}

Protection of human health and the environment is a general mandate of the RCRA statute (EPA, 1994). This mandate requires that the corrective action include any protective measures that 
are needed. These measures may or may not be directly related to media cleanup, source control, or management of wastes. The corrective action alternatives are evaluated for the ability to meet corrective action objectives as defined in Section 3.1.

\section{Compliance with Media Cleanup Standards}

Each corrective action alternative must have the ability to meet the proposed media cleanup standards as set forth in applicable state and federal regulations (445A [NAC, 1996b] and 459 [NAC, 1996c]). Factors on which an evaluation of cleanup standards must be based ([a] through [k] evaluation) are discussed in Section 3.3. Analytical results are discussed in Appendix A.

\section{Control the Source(s) of the Release}

An objective of a corrective action remedy is to stop further environmental degradation by controlling or eliminating additional releases that may pose a threat to human health and the environment. Unless source control measures are taken, efforts to clean up releases may be ineffective or, at best, will essentially involve a perpetual cleanup. Therefore, each corrective action alternative must use an effective source control program to ensure the long-term effectiveness and protectiveness of the corrective action.

\section{Comply with Applicable Federal, State, and Local Standards for Waste Management}

During implementation of any corrective action alternative, all waste management activities must be conducted in accordance with applicable state and federal regulations (e.g., Nevada Revised Statutes 459.400 - 459.600 [NRS, 1995]; RCRA 40 CFR 261 - 281 [CFR, 1996]; 40 CFR 268, “Land Disposal Restrictions," NAC 444, "Solid Waste Disposal” [NAC, 1996a]; and NAC 459.9974, "Disposal and Evaluation of Contaminated Soil" [NAC, 1996c]). The requirements for management of the waste, if any, derived from the corrective action will be determined based on applicable state and federal regulations, field observations, process knowledge, characterization data, and data collected and analyzed during corrective action implementation. Administrative controls (e.g., decontamination procedures and corrective action strategies) will minimize waste generated during site corrective action activities. Decontamination activities will be performed in accordance with approved procedures as specified in the NDEP-approved TTR work plan (DOE/NV, 1996a) and will be designated according to the COCs present at the site. 


\subsubsection{Remedy Selection Decision Factors}

The following describe the remedy selection decision factors used to evaluate the corrective action alternatives:

\section{Short-Term Reliability and Effectiveness}

Each corrective action alternative must be evaluated with respect to its effects on human health and the environment during the construction and implementation phase of the corrective action. The following factors will be addressed for each alternative:

- Protection of the community from potential risks associated with implementation such as fugitive dusts, transportation of hazardous materials, explosion

- Protection of workers during construction and implementation

- Environmental impacts that may result from construction and implementation

- The amount of time until the corrective action objectives are achieved

\section{Reduction of Toxicity, Mobility, and/or Volume}

Each corrective action alternative must be evaluated for its ability to reduce the toxicity, mobility, and/or volume of the contaminated media. Reduction in toxicity, mobility, and/or volume refers to changes in one or more characteristics of the contaminated media by the use of corrective measures that decrease the inherent threats associated with that media.

\section{Long-Term Reliability and Effectiveness}

Each corrective action alternative must be evaluated in terms of risk remaining at the CAU after the corrective action alternative has been implemented. The primary focus of this evaluation is on the extent and effectiveness of the controls that may be required to manage risk posed by treatment residuals and/or untreated wastes.

\section{Feasibility}

The feasibility criterion addresses the technical and administrative feasibility of implementing a corrective action alternative and the availability of services and materials needed during implementation. Each corrective action alternative must be evaluated for the following criteria: 
- Construction and Operation: This refers to the feasibility of implementing a corrective action alternative given the existing set of waste and site-specific conditions.

- Administrative Feasibility: This refers to the administrative activities needed to implement the corrective action alternative (e.g., permits, public acceptance, rights of way, off-site approval).

- Availability of Services and Materials: This refers to the availability of adequate off-site and on-site treatment, storage capacity, disposal services, necessary technical services and materials, and availability of prospective technologies for each corrective action alternative.

\section{Cost}

Costs for each alternative are estimated for comparison purposes only. The cost estimate for each corrective action alternative includes both capital and operation and maintenance (O\&M) costs, as applicable. The following is a brief description of each component:

- Capital Costs: These costs include both direct and indirect costs. Direct costs may consist of materials, labor, mobilization, demobilization, site preparation, construction materials, equipment purchase and rental, sampling and analysis, waste disposal, and health and safety measures. Indirect costs include such items as engineering design, permits and/or fees, start-up costs, and any contingency allowances.

- Operation and Maintenance: These costs include labor, training, sampling and analysis, maintenance materials, utilities, and health and safety measures.

Costs associated with potential O\&M activities are considered to be minimal for all alternatives and were, therefore, not estimated. Cost estimates were developed by Bechtel Nevada; details of the estimated costs for this CADD are provided in Appendix C.

\subsection{Development of Corrective Action Alternatives}

This section identifies and briefly describes the viable corrective action technologies and the corrective action alternatives considered for the affected media. Based on the review of existing data, future land use, and current operations at the TTR, the following alternatives have been developed for consideration at CAU 427:

- Alternative 1 - No Further Action

- Alternative 2 - Closure of Septic Tank 33-5 and Administrative Controls

- Alternative 3 - Closure of Septic Tank 33-5, Excavation, and Disposal 
In situ bioremediation was also considered; however, site conditions (e.g., small discrete pockets of relatively low-level contamination) do not warrant the added expense and complexity associated with implementation.

The following evaluation of NAC 445A.227 (2) (a-k) (NAC, 1996b) supports the protection of groundwater from site contaminants:

a. The depth to groundwater is 110 to $120 \mathrm{~m}$ (360 to $390 \mathrm{ft}$ ) (DOE/NV, 1996a). Because the sources to the leachfields have been rerouted to exclude SWS $2 \& 6$, a source no longer exists to contribute to plume size or migration. The precipitation for the area (13 to 15 centimeters [cm] [5 to 6 inches (in.)] annually) (DOE/NV, 1996a) does not influence the movement of the contaminants. Based on data from other subsurface investigations in Area 3, the biological environment should be favorable to natural biological degradation (DOE/NV, 1997a; $\mathrm{DOE} / \mathrm{NV}, 1998 \mathrm{~b}$ ). While the contaminants may continue to migrate vertically, the rate will be slow without a driving force, and the contaminants will continue to degrade over time.

b. The distance to the nearest drinking water well (Sandia 6) is $610 \mathrm{~m}(2,000 \mathrm{ft})$ southeast of the CAS. Groundwater movement in this area is to the northwest (DOE/NV, 1996a). The total areal extent of the individual contamination pockets as determined in the site investigation is limited to approximately 100 square meters $\left(\mathrm{m}^{2}\right)\left(1,100\right.$ square feet [ $\left.\mathrm{ft}^{2}\right]$ ) (see Figure A.2-2 in Appendix A). Therefore, for the contaminants to affect the drinking water well, they will need to travel the vertical distance to the groundwater, then travel through the groundwater in a direction opposite normal groundwater flow to the radius of influence of the well. Because the contamination has migrated only a short vertical distance and has had no appreciable lateral migration over the last 28 to 33 years and because the hydrocarbons will likely degrade naturally with time, the likelihood of any impacts to the well is minimal.

c. Geotechnical analysis of three samples taken below zones of contamination defined the soil as well-graded sand with silt and gravel and clayey sand with gravel. The porosity measured in the analysis ranged from 34 to 46 percent. Any silt or clay layers will only serve to impede migration of the contaminants. Low permeabilities were indicated by a range from $2.6 \times 10^{-6}$ to $9.8 \times 10^{-6}$ centimeters/second $(\mathrm{cm} / \mathrm{sec}$ ) (Appendix A). The higher the content of silts and clays, the higher the soil retention capability for the contaminants.

d. Annual precipitation averages 13 to $15 \mathrm{~cm}$ (5 to 6 in.). Annual evaporation is between 147 and $168 \mathrm{~cm}$ (58 and 66 in.) (DOE/NV, 1996a). The high evaporation and low precipitation create a negative water balance for the area; therefore, no driving force associated with precipitation is available to mobilize contaminants to groundwater. Ponding is not likely at the CAU because the ground surface slopes such that surface water runs off site.

e. The type of regulated substance released is petroleum hydrocarbons in the form of waste oil. Light, bulk hydrocarbons such as waste oil can migrate downward in unsaturated zone soil due to gravity and capillary forces. Downward migration is slowed by the following parameters: 
- Permeability of the soil

- Natural degradation of the hydrocarbons

- Limited volume of release

- Soil saturation

- Soil particle adsorption/desorption

Analysis of three subsurface soil samples obtained within the CAU defined the permeability to be low (ranging from $2.6 \times 10^{-6}$ to $9.8 \times 10^{-6}$ centimeters per second $[\mathrm{cm} / \mathrm{sec}]$ ) (Attachment 1 ). Based on data from other subsurface investigations in Area 3, the biological environment should be favorable to natural biological degradation (DOE/NV, 1997a; DOE/NV, 1998b). Because of the large distance to groundwater, the slow travel time associated with the gravity drainage mechanism for migration, the small size of the contaminant pockets, and the potential biologically favorable environment, the contaminants will not likely reach or impact the groundwater.

Without specific chemical analysis of the components of the waste oil at the CAU, a quantitative estimate of the risk is not possible. However, direct pathways to the contaminants do not currently exist. The only potential pathway would be inadvertent intrusion to the TPH-contaminated zone.

The highest TPH concentration detected in the investigation was $2,900 \mathrm{mg} / \mathrm{kg}$. The sample associated with this concentration was collected from the outfall end of Septic Tank 33-4 at a depth of $1.4 \mathrm{~m}$ to $1.5 \mathrm{~m}$ (4.5 ft to $5.0 \mathrm{ft})$. At this location, samples from boring “Tank 33-4-SB" had detected levels of TPH at $1,300 \mathrm{mg} / \mathrm{kg}$ from $2.3 \mathrm{~m}$ to $3.0 \mathrm{~m}(7.5 \mathrm{ft}$ to $10.0 \mathrm{ft})$ and nondetectable levels below $3 \mathrm{~m}(10.0 \mathrm{ft})$. Only 15 of the 123 samples collected had $\mathrm{TPH}$ concentrations above $100 \mathrm{mg} / \mathrm{kg}$ (Appendix A).

f. The extent of contamination is limited to five relatively small areas. The total lateral extent of contamination is estimated to be $100 \mathrm{~m}^{2}\left(1,100 \mathrm{ft}^{2}\right)$. The maximum vertical extent of contamination is no deeper than $10 \mathrm{~m}(33 \mathrm{ft})$. Because the source has been removed, it no longer contributes to the movement of the contaminants laterally and vertically. The deepest TPH concentration greater than $100 \mathrm{mg} / \mathrm{kg}$ was detected at $8.3 \mathrm{~m}(27.5 \mathrm{ft})$. Natural biological degradation of the waste oil should further limit the potential for contaminants to reach groundwater.

g. Presently, the CAU is located in a government-controlled facility with the potential future land use similar to current use. The TTR is a restricted area that is guarded on a 24-hour, 365-day-per-year basis; unauthorized personnel are not admitted to the facility. The CAU is currently covered by a minimum of a $0.8 \mathrm{~m}(2.5 \mathrm{ft})$ clean soil cover, preventing inadvertent access to high concentrations of contaminants which are located at a minimum depth of $1.3 \mathrm{~m}$ $(4.3 \mathrm{ft})$ below the surface. Alternatives will be evaluated for control of inadvertent intrusion into the contaminated zone.

h. Preferred routes of migration are extremely limited or nonexistent since the point sources of the TPH have been removed and the surface area is covered by a minimum of a $0.8 \mathrm{~m}(2.5 \mathrm{ft})$ clean 
soil cover. Inadvertent intrusion is the only pathway from the contaminants to potential receptors.

i. The subsurface TPH is located beneath a minimum $0.8 \mathrm{~m}(2.5 \mathrm{ft})$ clean soil cover. Building 03-70 is located near, and potentially over, contamination associated with the 1965-1975 Leachfield. Numerous buried utilities cross this area.

j. The potential for a hazard related to fire, vapor, or explosion is very low because the TPH is located below the surface under a minimum of a $0.8 \mathrm{~m}(2.5 \mathrm{ft})$ clean soil cover. The fire and explosion potential for waste oil is moderate when exposed to fire or flame, neither of which are applicable to the buried contaminants at the CAU.

k. No other site-specific factors are known at this time.

Based on this evaluation, impacts to groundwater are not expected. Therefore, groundwater monitoring is not proposed for this site and is not considered an element of the alternatives.

\subsubsection{Alternative 1 - No Further Action}

Under the No Further Action alternative, no corrective action activities will be implemented. This alternative is used as a starting point to establish a baseline for comparison with the other corrective action alternatives. This alternative does not meet the corrective action objectives because no actions are taken to prevent human contact with the COCs. This alternative will not be compared to the other alternatives using the selection decision factors.

\subsubsection{Alternative 2 - Closure of Septic Tank 33-5 and Administrative Controls}

Administrative controls are used to prevent inadvertent contact with contaminated media. Administrative controls would consist of land-use restrictions to prevent intrusive activities. Based on data from other subsurface investigations in Area 3, the biological environment should be favorable to natural biological degradation (DOE/NV, 1997a; DOE/NV, 1998b). Natural biological activity will likely result in reduced concentrations of hydrocarbons with time. Administrative controls are commonly used and can effectively eliminate potential pathways. Administrative controls are effective because the TTR, which includes CAU 427, is a restricted-access facility. The implementation of administrative controls requires the coordination of all entities at a facility to ensure that the restrictions are enforced. An evaluation of the NAC 445A.227 (2) (a - k) (NAC, 1996b) requirements is presented in Section 3.3. This evaluation provides evidence that 
conditions at the CAU will not adversely impact the groundwater beneath the CAU or any nearby drinking water wells.

Septic Tank 33-5 should be closed in accordance with NAC 459 (NAC, 1996c). The estimated 5,150 liters (1,360 gallons) of septage remaining in the tank would be sampled to determine its chemical characteristics and pumped into approved containers for proper disposal. The tank would then be either filled in place with an inert material to prevent subsidence, or removed and disposed of in accordance with applicable regulations depending on the condition of the tank and COCs present (NAC, 1996c).

\subsubsection{Alternative 3 - Closure of Septic Tank 33-5, Excavation, and Disposal}

Alternative 3 consists of removing the soil and associated piping contaminated at levels above $100 \mathrm{mg} / \mathrm{kg}$ and disposing of this waste in an approved disposal facility. The excavated areas will be backfilled with uncontaminated soils and returned to original surface conditions. Excavation would be used to remove clean borrow soil from a nearby location for placement in the remaining voids as necessary.

The zone of soil contaminated at levels above $100 \mathrm{mg} / \mathrm{kg}$ associated with the $1965-1975$ Leachfield may extend beneath Building 03-70. The concentrations of TPH decreased in the downstream direction of leachate flow. The Dbox-RS-SB (the sample location furthest downstream before the building) samples did not have detectable levels of TPH; therefore, the soil beneath Building 03-70 will likely be suitable to leave in place. Confirmatory sampling of the excavation walls should be performed to ensure removal of the higher concentrations of waste oil. If the contamination extends below Building 03-70, the building itself will inhibit inadvertent intrusion to potentially contaminated soil beneath it; however, land-use restrictions should also be implemented to notify workers of the potential hazards in the event of underground utility maintenance or installation.

Septic Tank 33-5 would be closed in accordance with NAC 459 (NAC, 1996c) as described in Section 2.3 and 3.3.2. 


\subsection{Evaluation and Comparison of Alternatives}

The general corrective action standards and remedy selection decision factors described in Section 3.2 were used to conduct detailed and comparative analyses of each corrective action alternative. The advantages and disadvantages of each alternative were assessed to select a preferred alternative for CAU 427. Table 3-1 presents a summary of the detailed analysis of the alternatives. Table 3-2 presents the comparative analysis of alternatives. A cost estimate summary is provided in Appendix C. 
Table 3-1

Detailed Evaluation of Alternatives

(Page 1 of 4 )

\begin{tabular}{|c|c|c|c|}
\hline Evaluation Criteria & $\begin{array}{c}\text { Alternative } 1 \\
\text { No Further Action }\end{array}$ & $\begin{array}{c}\text { Alternative } 2 \\
\text { Closure of Septic Tank } 33-5 \text { and } \\
\text { Administrative Controls }\end{array}$ & $\begin{array}{c}\text { Alternative } 3 \\
\text { Closure of Septic Tank 33-5, } \\
\text { Excavation, and Disposal }\end{array}$ \\
\hline \multicolumn{4}{|c|}{ Closure Standards } \\
\hline $\begin{array}{l}\text { Protection of Human Health } \\
\text { and the Environment }\end{array}$ & $\begin{array}{l}\text { - TPH as waste oil was identified } \\
\text { above } 100 \mathrm{mg} / \mathrm{kg} \text { and will remain in } \\
\text { soil } \\
\text { - Does not meet corrective action } \\
\text { objective of preventing inadvertent } \\
\text { intrusion into the contaminated soil } \\
\text { zone } \\
\text { - No action implemented to close } \\
\text { Septic Tank } 33-5 \\
\text { - No worker exposure associated with } \\
\text { implementation } \\
\text { NAC } 445 A .227 \text { (2) (a-k), analysis } \\
\text { shows the contaminants are not } \\
\text { impacting groundwater. }\end{array}$ & $\begin{array}{l}\text { - } \text { TPH as waste oil was identified } \\
\text { above } 100 \mathrm{mg} / \mathrm{kg} \text { and will remain in } \\
\text { soil } \\
\text { - } \quad \text { Meets corrective action objectives } \\
\text { - } \quad \text { Prevents inadvertent intrusion into } \\
\text { the contaminated soil zone. } \\
\text { - Septic Tank } 33-5 \text { will be closed in } \\
\text { accordance with NAC } 459 \text {. } \\
\text { - NAC } 445 A .227(2)(\mathrm{a}-\mathrm{k}) \text {, analysis } \\
\text { shows the contaminants are not } \\
\text { impacting groundwater. } \\
\text { - Limited worker exposure associated } \\
\text { with tank closure } \\
\text { Low risk to public because of remote } \\
\text { location and controlled access to the } \\
\text { TTR }\end{array}$ & $\begin{array}{l}\text { - TPH levels will be reduced to } \\
100 \mathrm{mg} / \mathrm{kg} \text {. } \\
\text { - } \quad \text { Meets corrective action objectives } \\
\text { - } \quad \text { Septic Tank } 33-5 \text { will be closed in } \\
\text { accordance with NAC } 459 \text {. } \\
\text { - } \quad \text { Relatively low risk to workers } \\
\text { associated with heavy equipment } \\
\text { operation and potential exposure to } \\
\text { TPH contamination } \\
\text { - Low risk to public because of remote } \\
\text { location and controlled access to the } \\
\text { TTR } \\
\text { NAC } 445 A .227 \text { (2) (a-k), analysis } \\
\text { shows the contaminants are not } \\
\text { impacting groundwater. }\end{array}$ \\
\hline
\end{tabular}


Table 3-1

Detailed Evaluation of Alternatives

(Page 2 of 4 )

\begin{tabular}{|c|c|c|c|}
\hline Evaluation Criteria & $\begin{array}{c}\text { Alternative } 1 \\
\text { No Further Action }\end{array}$ & $\begin{array}{c}\text { Alternative } 2 \\
\text { Closure of Septic Tank } 33-5 \text { and } \\
\text { Administrative Controls }\end{array}$ & $\begin{array}{c}\text { Alternative } 3 \\
\text { Closure of Septic Tank 33-5, } \\
\text { Excavation, and Disposal }\end{array}$ \\
\hline $\begin{array}{l}\text { Compliance with Media } \\
\text { Cleanup Standards }\end{array}$ & $\begin{array}{l}\text { - Does not comply with media cleanup } \\
\text { standards because TPH remains at } \\
\text { levels above } 100 \mathrm{mg} / \mathrm{kg} \text {, and no } \\
\text { corrective action is taken to prevent } \\
\text { inadvertent intrusion. } \\
\text { - No action implemented to close } \\
\text { Septic Tank } 33-5 \\
\text { - NAC } 445 \mathrm{~A} .227(2)(\mathrm{a}-\mathrm{k}) \text {, analysis } \\
\text { shows the contaminants are not } \\
\text { impacting groundwater. } \\
\text { - Some natural biological activity will } \\
\text { likely result in lower concentrations } \\
\text { over time. }\end{array}$ & $\begin{array}{l}\text { - Complies with media cleanup } \\
\text { standards by eliminating exposure } \\
\text { pathways } \\
\text { Some natural biological activity will } \\
\text { likely result in lower concentrations } \\
\text { over time, and protections are } \\
\text { provided to prevent human exposure } \\
\text { to the contaminated soil through } \\
\text { intrusive activities. } \\
\text { NAC } 445 A .227 \text { (2) (a-k), analysis } \\
\text { shows the contaminants are not } \\
\text { impacting groundwater. } \\
\text { The levels identified do not } \\
\text { significantly exceed the } 100 \text { mg/kg } \\
\text { regulatory action level for corrective } \\
\text { action. } \\
\text { Septic Tank } 33-5 \text { will be closed in } \\
\text { accordance with NAC } 459 \text {. }\end{array}$ & $\begin{array}{l}\text { - Complies with media cleanup } \\
\text { standards because } \\
\text { TPH-contaminated subsurface soil } \\
\text { above the } 100 \mathrm{mg} / \mathrm{kg} \text { action level will } \\
\text { be excavated and disposed of } \\
\text { off-site. } \\
\text { - Cleanup standards will be verified } \\
\text { with confirmation sampling. } \\
\text { - Septic Tank } 33-5 \text { will be closed in } \\
\text { accordance with NAC } 459 \text {. } \\
\text { NAC } 445 A .227 \text { (2) (a-k), analysis } \\
\text { shows the contaminants are not } \\
\text { impacting groundwater. }\end{array}$ \\
\hline $\begin{array}{l}\text { Control the Source(s) of } \\
\text { Release }\end{array}$ & $\begin{array}{l}\text { The source(s) to the leachfields and } \\
\text { septic tanks have been rerouted. } \\
\text { TPH levels greater than the } \\
100 \mathrm{mg} / \mathrm{kg} \text { action level remain in } \\
\text { place } \\
\text { No actions implemented to close } \\
\text { Septic Tank } 33-5\end{array}$ & $\begin{array}{l}\text { The source(s) to the leachfields and } \\
\text { septic tanks have been rerouted. } \\
\text { TPH levels greater than the } 100 \\
\text { mg/kg action level remain in place } \\
\text { - Septic Tank } 33-5 \text { will be closed in } \\
\text { accordance with NAC } 459 \text {. }\end{array}$ & $\begin{array}{l}\text { - The source(s) to the leachfields and } \\
\text { septic tanks have been rerouted. } \\
\text { TPH-contaminated subsurface soil } \\
\text { above the } 100 \mathrm{mg} / \mathrm{kg} \text { action level will } \\
\text { be excavated and transported to an } \\
\text { appropriate treatment or disposal } \\
\text { facility. } \\
\text { - Septic Tank } 33-5 \text { will be closed in } \\
\text { accordance with NAC } 459 \text {. }\end{array}$ \\
\hline
\end{tabular}


Table 3-1

Detailed Evaluation of Alternatives

(Page 3 of 4 )

\begin{tabular}{|c|c|c|c|}
\hline Evaluation Criteria & $\begin{array}{c}\text { Alternative } 1 \\
\text { No Further Action }\end{array}$ & $\begin{array}{c}\text { Alternative } 2 \\
\text { Closure of Septic Tank } 33-5 \text { and } \\
\text { Administrative Controls }\end{array}$ & $\begin{array}{c}\text { Alternative } 3 \\
\text { Closure of Septic Tank 33-5, } \\
\text { Excavation, and Disposal }\end{array}$ \\
\hline $\begin{array}{l}\text { Comply with Applicable } \\
\text { Federal, State, and Local } \\
\text { Standards for Waste } \\
\text { Management }\end{array}$ & No waste generated & $\begin{array}{l}\text { Waste would only be generated } \\
\text { during the removal of Septic Tank } \\
\text { 33-5. } \\
\text { The associated septage and tank will } \\
\text { be handled and disposed of per } \\
\text { applicable standards. }\end{array}$ & $\begin{array}{l}\text { Approximately } 230 \text { cubic yards }\left(\mathrm{yd}^{3}\right) \\
\text { of TPH-contaminated soil waste } \\
\text { would be generated. } \\
\text { Waste would be generated during the } \\
\text { removal of Septic Tank } 33-5 \text {. } \\
\text { All waste will be handled and } \\
\text { disposed of per applicable standards. }\end{array}$ \\
\hline \multicolumn{4}{|c|}{ Remedy Selection Decision Factors } \\
\hline $\begin{array}{l}\text { Short-Term Reliability and } \\
\text { Effectiveness }\end{array}$ & Not evaluated & $\begin{array}{l}\text { Only minimal risk to workers } \\
\text { associated with closure of Septic } \\
\text { Tank 33-5. } \\
\text { Public protected by remote location } \\
\text { and TTR site access controls }\end{array}$ & $\begin{array}{l}\text { Risk to workers associated with } \\
\text { removal of TPH-contaminated soil } \\
\text { and closure of Septic Tank 33-5. } \\
\text { Public protected by remote location } \\
\text { and TTR site access controls }\end{array}$ \\
\hline $\begin{array}{l}\text { Reduction of Toxicity, } \\
\text { Mobility, and/or Volume }\end{array}$ & Not evaluated & $\begin{array}{l}\text { - Natural attenuation will likely result in } \\
\text { a decrease in toxicity, mobility, and } \\
\text { volume of the contaminated soil with } \\
\text { time. } \\
\text { - Permanent closure of Septic Tank } \\
\text { 33-5 in accordance with NAC } 459 \\
\text { would effectively eliminate } \\
\text { associated toxicity, mobility, and } \\
\text { volume of wastes. }\end{array}$ & $\begin{array}{l}\text { Removal of TPH-contaminated soil } \\
\text { above } 100 \mathrm{mg} / \mathrm{kg} \text { and closure of } \\
\text { Septic Tank 33-5 (in accordance with } \\
\text { NAC 459) reduces all three } \\
\text { characteristics at this CAU. } \\
\text { The disposal facility's handling } \\
\text { procedures will determine the } \\
\text { characteristics after removal from the } \\
\text { CAU. }\end{array}$ \\
\hline $\begin{array}{l}\text { Long-Term Reliability and } \\
\text { Effectiveness }\end{array}$ & Not evaluated & $\begin{array}{l}\text { - } \text { Controls inadvertent intrusion } \\
\text { - Septic Tank 33-5 permanently closed } \\
\text { - } \quad \text { Administrative controls required }\end{array}$ & $\begin{array}{l}\text { - All risk will be eliminated upon } \\
\text { completion. } \\
\text { - No maintenance required }\end{array}$ \\
\hline
\end{tabular}


Table 3-1

Detailed Evaluation of Alternatives

(Page 4 of 4 )

\begin{tabular}{|c|c|c|c|}
\hline Evaluation Criteria & $\begin{array}{c}\text { Alternative } 1 \\
\text { No Further Action }\end{array}$ & $\begin{array}{c}\text { Alternative } 2 \\
\text { Closure of Septic Tank } 33-5 \text { and } \\
\text { Administrative Controls }\end{array}$ & $\begin{array}{c}\text { Alternative } 3 \\
\text { Closure of Septic Tank 33-5, } \\
\text { Excavation, and Disposal }\end{array}$ \\
\hline Feasibility & Not evaluated & $\begin{array}{l}\text { - Easily implementable } \\
\text { - Coordination of all entities is } \\
\text { necessary to ensure compliance to } \\
\text { prevent intrusion into contaminated } \\
\text { soil zones. }\end{array}$ & $\begin{array}{l}\text { - An existing, active building and } \\
\text { numerous underground utilities are } \\
\text { present at the CAU. Special } \\
\text { consideration will be required during } \\
\text { excavation, and access to the } \\
\text { underlying contaminated soils may } \\
\text { be difficult. } \\
\text { Closure of Septic Tank } 33-5 \text { is easily } \\
\text { implementable. }\end{array}$ \\
\hline Cost & $\$ 0$ & $\$ 70,478^{*}$ & $\$ 145,882^{*}$ \\
\hline
\end{tabular}

*Included estimate for closure in place of Septic Tank 33-5. 
Table 3-2

Comparative Evaluation of Alternatives

(Page 1 of 2)

\begin{tabular}{|c|c|}
\hline Evaluation Criteria & Comparative Evaluation \\
\hline \multicolumn{2}{|r|}{ Closure Standards } \\
\hline $\begin{array}{l}\text { Protection of Human Health and } \\
\text { the Environment }\end{array}$ & $\begin{array}{l}\text { Alternatives } 2 \text { and } 3 \text { meet corrective action objectives; Alternative } 1 \text { does not. No worker exposure to risks associated with } \\
\text { Alternative } 1 . \text { Minor risks are associated with Alternative } 2 \text { and slightly higher risks with Alternative } 3 \text {. NAC } 445 A .227 \text { (2) } \\
\text { (a-k) analysis shows the contaminants are not impacting groundwater. }\end{array}$ \\
\hline $\begin{array}{l}\text { Compliance with Media Cleanup } \\
\text { Standards }\end{array}$ & $\begin{array}{l}\text { Alternatives } 1 \text { and } 2 \text { do not comply with media cleanup standards; however, natural biological degradation will likely result } \\
\text { in decreased concentrations with time. Alternative } 3 \text { meets media cleanup standards by removing levels of contamination } \\
\text { to cleanup standards and reducing exposure pathways. Alternative } 2 \text { controls access to contaminants, effectively } \\
\text { eliminating exposure pathways. }\end{array}$ \\
\hline $\begin{array}{l}\text { Control the Source(s) of the } \\
\text { Release }\end{array}$ & $\begin{array}{l}\text { The source to the leachfields and septic tanks has been rerouted. Alternative } 1 \text { does not control future release from Septic } \\
\text { Tank 33-5; Alternatives } 2 \text { and } 3 \text { do. Exposure to subsurface contaminated soil is controlled by Alternatives } 2 \text { and } 3 \text {, not by } \\
\text { Alternative } 1 \text {. }\end{array}$ \\
\hline $\begin{array}{l}\text { Comply with Applicable Federal, } \\
\text { State, and Local Standards for } \\
\text { Waste Management }\end{array}$ & $\begin{array}{l}\text { Alternative } 1 \text { does not generate any waste. Alternative } 2 \text { only generates waste associated with closure of Septic Tank } \\
\text { 33-5. Alternative } 3 \text { generates the same waste as Alternative } 2 \text { as well as approximately } 230 \mathrm{yd}^{3} \text { of TPH-contaminated soil. } \\
\text { All waste will be managed and disposed of per applicable standards. }\end{array}$ \\
\hline \multicolumn{2}{|r|}{ Remedy Selection Decision Factors } \\
\hline $\begin{array}{l}\text { Short-Term Reliability and } \\
\text { Effectiveness }\end{array}$ & Minor risks are associated with Alternative 2 and slightly higher risks with Alternative 3. \\
\hline $\begin{array}{l}\text { Reduction of Toxicity, Mobility, } \\
\text { and/or Volume }\end{array}$ & $\begin{array}{l}\text { Alternatives } 2 \text { and } 3 \text { result in a reduction of all three characteristics at this CAU for Septic Tank } 33-5 \text {. For Alternative } 2 \text {, } \\
\text { only natural attenuation will likely reduce these characteristics with time. Alternative } 3 \text { reduces all three parameters by } \\
\text { removal from the site. }\end{array}$ \\
\hline $\begin{array}{l}\text { Long-Term Reliability and } \\
\text { Effectiveness }\end{array}$ & $\begin{array}{l}\text { Residual risk is low for } 2 \text { and nonexistent for Alternative } 3 \text {. Alternative } 2 \text { requires some administrative measures to control } \\
\text { intrusive activities associated with future utility maintenance and installation. Alternative } 3 \text { closes the CAU upon } \\
\text { completion. }\end{array}$ \\
\hline Feasibility & $\begin{array}{l}\text { Alternatives } 2 \text { and } 3 \text { are feasible; however, Alternative } 3 \text { requires special consideration of the nearby building and } \\
\text { underground utilities during excavation activities. Both require heavy equipment, operating personnel, and disposal of } \\
\text { wastes. Alternative } 2 \text { is the most feasible. }\end{array}$ \\
\hline
\end{tabular}


Table 3-2

Page 26 of 29

\section{Comparative Evaluation of Alternatives}

(Page 2 of 2)

\begin{tabular}{||l|l||}
\hline \multicolumn{1}{|c|}{ Evaluation Criteria } & \multicolumn{1}{|c|}{ Comparative Evaluation } \\
\hline \hline \multicolumn{1}{|c|}{ Closure Standards } \\
\hline \hline Cost & $\begin{array}{l}\text { The cost for Alternative 1 is } \$ 0 \text {. The cost for Alternative 2 is } \$ 70,478^{*} \text { for implementation of administrative controls and } \\
\text { closure of Septic Tank 33-5. Alternative } 3 \text { is estimated to cost } \$ 145,882^{*} \text { for removal and disposal of TPH-contaminated } \\
\text { soil and closure of Septic Tank 33-5. }\end{array}$ \\
\hline
\end{tabular}

*Included estimate for closure in place of Septic Tank 33-5. 


\subsection{Recommended Alternative}

Based on the results of the detailed and comparative analysis of the potential corrective action alternatives presented in this document, the preferred corrective action alternative selected for implementation at CAU 427 is Alternative 2, Closure of Septic Tank 33-5 and Administrative Controls. Alternative 2 was chosen for the following reasons:

- It minimizes health risks by preventing public and worker access to the contaminated soil and contents of Septic Tank 33-5.

- It complies with standards for management of wastes because minimal wastes are generated, and all waste will be managed in accordance federal, state, and local requirements.

- $\quad$ Long-term risks are minimized by controlling access to the site.

- It is easily implementable with only a slight potential for disturbance of subsurface utilities during removal Septic Tank 33-5.

- It provides the most cost-effective method for achieving protection and for meeting closure requirements.

The preferred corrective action alternative was evaluated on its technical merits, focusing on performance, reliability, feasibility, and safety. The alternative was judged to meet all requirements for the technical components evaluated. The alternative meets all applicable state and federal regulations for closure of the site and will reduce potential future exposure pathways to the contaminated soil and the contents of Septic Tank 33-5.

During corrective action implementation, this alternative will present minimal potential threat to site workers. However, appropriate health and safety procedures will be developed and implemented.

The future use of any land related to this CAU, as described by this CADD, would be restricted from any activity that may alter or modify the containment control as approved by the State and identified in the CAU Closure Report or other CAU documentation unless appropriate concurrence is obtained in advance.

Based on the evaluation in this CADD, Closure of Septic Tank 33-5 and Administrative Controls is the preferred closure method for Septic Waste Systems 2 and 6. 


\subsection{References}

CFR, see Code of Federal Regulations.

Code of Federal Regulations. 1996. Title 40 CFR Parts 260 - 281, "RCRA Regulations."

Washington, DC: U.S. Government Printing Office.

DOE/NV, see U.S. Department of Energy, Nevada Operations Office.

EPA, see U.S. Environmental Protection Agency.

FFACO, see Federal Facility Agreement and Consent Order.

Federal Facility Agreement and Consent Order. 1996. Agreed to by the State of Nevada, the U.S. Department of Energy, and the U.S. Department of Defense.

NAC, see Nevada Administrative Code.

Nevada Administrative Code. 1996a. NAC 444, "Solid Waste Disposal.” Carson City, NV.

Nevada Administrative Code. 1996b. NAC 445A, "Water Pollution Control." Carson City, NV.

Nevada Administrative Code. 1996c. NAC 459, "Disposal and Evaluation of Contaminated Soil." Carson City, NV.

NRS, see Nevada Revised Statutes.

Nevada Revised Statutes. 1995. NRS 459.400-459.600, "Disposal of Hazardous Waste." Carson City, NV.

U.S. Department of Energy, Nevada Operations Office. 1994. Project Management Plan, Rev. 0. Las Vegas, NV.

U.S. Department of Energy, Nevada Operations Office. 1996a. Corrective Action Unit Work Plan, Tonopah Test Range, Nevada, DOE/NV-426. Las Vegas, NV: IT Corporation.

U.S. Department of Energy, Nevada Operations Office. 1996b. Final Environmental Impact Statement for the Nevada Test Site and Off-Site Locations in the State of Nevada, Volume I, DOE/EIS 0243. Las Vegas, NV.

U.S. Department of Energy, Nevada Operations Office. 1996c. Industrial Sites Quality Assurance Project Plan, DOE/NV-425. Las Vegas, NV. 
U.S. Department of Energy, Nevada Operations Office. 1997a. Corrective Action Decision Document, Second Gas Station, Tonopah Test Range, Nevada (Corrective Action Unit No. 403), DOE/NV--471, UC 700, Rev. 2. Las Vegas, NV: IT Corporation.

U.S. Department of Energy, Nevada Operations Office. 1997b. Corrective Action Investigation Plan for Corrective Action Unit No. 427: Area 3 Septic Waste System Numbers 2 and 6, Tonopah Test Range, Nevada, DOE/NV--488, UC 700, Rev. 0. Las Vegas, NV: IT Corporation.

U.S. Department of Energy, Nevada Operations Office. 1998a. Corrective Action Decision Document for the Area 3 Landfill Complex, Tonopah Test Range, CAU 424, DOE/NV--496, UC 700, Rev. 0. Las Vegas, NV: IT Corporation.

U.S. Department of Energy, Nevada Operations Office. 1998b. Corrective Action Decision Document for the Building 03-60 Underground Discharge Point, Tonopah Test Range, CAU 423, DOE/NV--508, UC 700, Rev. 0. Las Vegas, NV: IT Corporation.

U.S. Environmental Protection Agency. 1991. Guidance on Resource Conservation and Recovery Act (RCRA) Corrective Action Decision Documents, EPA/540/G-91/011. Washington, DC: Office of Research and Development

U.S. Environmental Protection Agency. 1994. Final RCRA Corrective Action Plan, EPA/520-R-94-004. Washington, DC: Office of Solid Waste and Emergency Response. 


\section{Appendix A}

Corrective Action Investigation Report for CAU 427: Area 3 Septic Waste Systems 2 and 6, Tonopah Test Range, Nevada 


\section{A.1.0 Introduction}

The report contained in this appendix presents the investigation activities and analytical results from the corrective action investigation conducted at the Area 3 Compound, CAU 427, which is located at the Tonopah Test Range, Nevada. Corrective Action Unit 427 is comprised of Septic Waste Systems 2 and 6 with respective CAS Numbers 03-05-002-SW02 and 03-05-002-SW06 (DOE/NV, 1996a). The septic waste systems are presented in Table 3-1 of the Corrective Action Unit Work Plan, Tonopah Test Range (DOE/NV, 1996a) (hereafter referred to as the TTR Work Plan). The corrective action investigation was conducted in accordance with the requirements set forth in the CAIP for CAU 427: Area 3 Septic Waste System Numbers 2 and 6, Tonopah Test Range, Nevada (DOE/NV, 1997a) as developed under the Federal Facility Agreement and Consent Order (FFACO, 1996).

The CAU is located in Area 3 of the TTR, Nye County, Nevada (see Figure 1-1 and Figure 1-2 of the Corrective Action Decision Document). The septic waste systems were installed to receive sanitary and industrial liquid wastes generated from site maintenance and other daily operations conducted at the Area 3 Compound (DOE/NV, 1996a). Septic Waste Systems 2 \& 6 were in operation during different time intervals from 1960 through 1990. Process knowledge of early septic operations regarding disposal practices and composition of wastestreams is limited (DOE/NV, 1997a). Additionally, specific details of the installation of subsurface components and the composition and condition of the collection system network were unknown prior to this investigation.

Additional information relating to the site history, planning, and scope of the investigation is presented in the CAIP (DOE/NV, 1997a) and the TTR Work Plan (DOE/NV, 1996a) and is not repeated in this report.

\section{A.1.1 Project Objectives}

The primary objectives for this project were to identify the vertical and lateral extent of possible contaminant migration from the leachfields and associated collection system components, to ascertain the potential impact to human health and the environment, and to provide sufficient information and data to develop appropriate corrective action alternatives for the septic waste systems. 
The DQO process outlined in the CAIP (DOE/NV, 1997a) proposed an evaluation of: the possible number of leachfields, status of collection system piping and associated septic tanks, and the configuration and exact location of subsurface components. Potential migration pathways for possible contaminant sources from the septic waste systems were also discussed. Subsurface soil was investigated by conducting an exploratory trenching and subsurface drilling program and by collecting environmental samples for both field screening and laboratory analysis. To optimize the sampling program, the exploratory trenches were positioned to transect both proximal and distal locations representative of each found leachfield. Excavations were also conducted at distribution points and septic tank outfalls which have increased potential to impact the surrounding soil in the event of unplanned releases. Environmental soil samples were collected at selected locations and depths. Soil borings were also conducted and core samples collected via split-spoon sampling as needed for step-out locations or to define the vertical extent of contamination. In addition, a video survey of subsurface piping was conducted, and the status and contents of the septic tanks that were found were investigated.

\section{A.1.2 Report Content}

This Corrective Action Investigation Report is intended to provide information and data in sufficient detail to support the selection of one of the preferred corrective action alternatives in the CADD. The contents of this report are as follows:

- Section A.1.0 describes the investigation background, objectives, and the report content.

- Section A.2.0 provides information regarding the field activities and sampling method.

- Section A.3.0 summarizes the results of the laboratory analysis from the investigation sampling.

- Section A.4.0 discusses the quality assurance (QA) and quality control (QC) procedures that were followed and the results of the QA and QC activities.

- Section A.5.0 is a summary of the results pertaining to the Area 3 SWS 2 and 6 corrective action investigation program.

- Section A.6.0 cites the references. 
- Attachment 1 includes the geotechnical information pertinent to the corrective action decision process.

- Appendix B includes the soil boring logs.

To make this report a concise summary, the complete field documentation and laboratory data, including Field Activity Daily Logs, Sample Collection Logs, Analysis Request/Chain-of-Custody Forms, soil sample descriptions, laboratory certificates of analyses, analytical results, and surveillance results are not contained in this report. These documents are retained in project files as both hard copy files and electronic media and will be supplied upon request. 


\section{A.2.0 Field Investigation and Sampling Activities}

Field investigation and sampling activities were divided into three separate phases. The first phase consisted of exploratory trenching with a backhoe to define the leachfields, four septic tank investigations, pipeline video surveys to explore and map the collection system network, and submittal of environmental soil samples on a quick turn-around schedule. A second phase consisted of evaluating analytical results to guide drilling and assist with waste management decisions, and then backfilling the safeguarded trenches with clean spoils piles. These phases were consecutive to minimize impact to ongoing operations at the Area 3 Compound and to prepare the site for drilling. The third phase consisted of hollow-stem auger coring at selected locations based upon analytical results from the environmental soil samples obtained during trenching. The three phases were completed during the time period from October 27 to December 19, 1997, with a brief continuation January 6 and 7, 1998, when one additional septic tank was investigated and the outfall end sampled.

The investigation and sampling program was managed in accordance with the requirements set forth in the CAIP (DOE/NV, 1997a). The field activities were performed in accordance with an approved Site-Specific Health and Safety Plan (IT, 1997). The samples were collected and documented by following approved sampling plans, and documented using field activity logs; sample collection logs; and decontamination, chain of custody, shipping, and radiation screening protocols, procedures, and field sampling instructions as indicated in the CAIP (DOE/NV, 1997a). Quality control samples (e.g., field blanks, rinsate blanks, trip blanks, and sample duplicates) were collected as required by the Industrial Sites Quality Assurance Project Plan (QAPP) (DOE/NV, 1996b) and approved procedures. During field activities, waste minimization practices were followed according to approved instructions and procedures, including segregation of the waste from discrete locations, segregation of suspected contaminated items from uncontaminated items, and separation of personal protective equipment into bags.

\section{A.2.1 Site Description and Conditions}

Septic Waste Systems 2 and 6 are located within the southwest portion of the Area 3 Compound at the TTR. The initial collection system and leachfield locations were based on interpretations of engineering drawings, interviews with former and current employees, and historical aerial 
photographs (DOE/NV, 1997a). Locations for initial excavations were based on the Attribute Composite Map, as presented in the CAIP (DOE/NV, 1997a) (Figure A.2-1). The actual leachfield boundaries, distribution lines, and septic tanks were located through exploratory trenching.

\section{A.2.2 Past Geophysical Surveys}

Two geophysical surveys were conducted in Area 3 to identify and delineate the leachfields and to locate septic tanks. The surveys were conducted by IT personnel in July and November 1993, and September 1996 (DOE/NV, 1997b). The results for SWS $2 \& 6$ were inconclusive as both surveys encountered extensive interference due to the presence of other underground utilities.

\section{A.2.3 Sampling Logistics}

This section describes the trenching and boring locations and sample collection activities for the SWS $2 \& 6$ corrective action investigation. Both soil grab-samples and borehole core-samples were collected from specified intervals for laboratory and field-screening analyses as well as for detailed field observations and lithologic description of the subsurface soil conditions.

\section{A.2.3.1 Trenching and Other Excavations}

Two trenches were excavated at each of the five potential leachfield locations (one leachfield associated with SWS 6 and four leachfields associated with SWS 2). These trenching activities discovered three leachfields in SWS $2 \& 6$. Once located, each leachfield was exposed along two transect excavations perpendicular to the distribution lines: one near the distribution box and the other near the distal end of the leachfield. Two excavations were conducted in attempts to expose distribution point centers at two of the leachfields. Four additional excavations were completed to reveal the existence of three septic tanks.

Based on historical information, interviews, engineering drawings, and interpretive conclusions, a chronology of septic system installations was derived from the investigation, and names for the individual leachfields are assigned accordingly. The three leachfields are: Pre-1965 Leachfield, 1965-1975 Leachfield, and Post-1975 Leachfield (Figure A.2-2). The individual leachfields and respective trenches are discussed later in this section. Activities in the early 1990s eliminated the last of the three former systems. The discrete systems were replaced during the Sandia National 


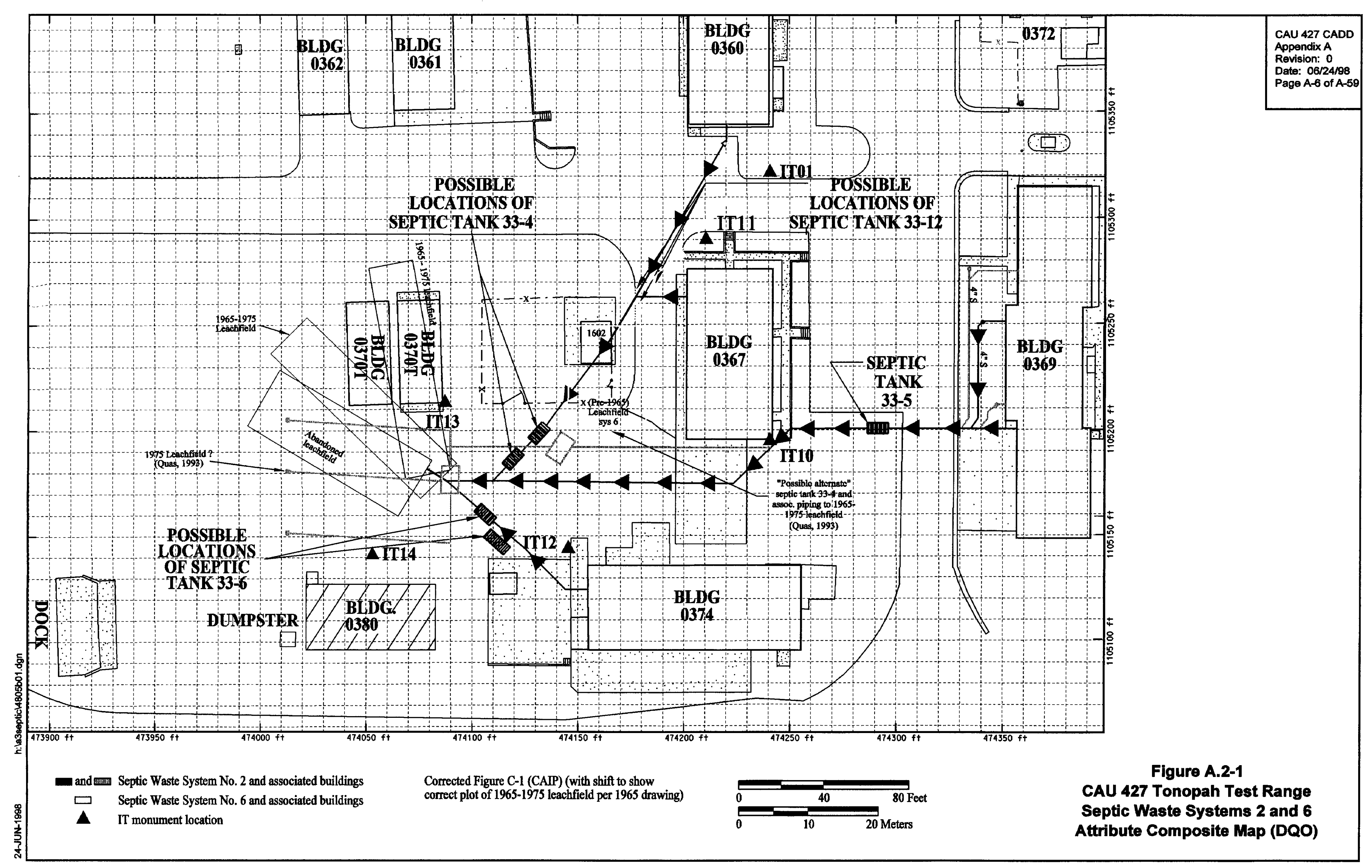


Laboratories' (SNL) consolidated sewer system installation, and wastewaters were rerouted through the new system. Excavations at key locations and junctions confirmed the "active" status of the SNL system, and by utilizing the video survey camera, the network was further defined (Figure A.2-2).

In general, trenching activities consisted of an exploratory excavation to expose just enough pipe or material to visually assess the placement of subsurface components. Selected distribution lines and the network of piping associated with the collection system were mapped using the video survey. Then excavations were performed to access sampling intervals. The interval, from one foot above the basement of the leachbed, defined the uppermost sampling interval. A lower sample was also collected from a second horizon $0.75 \mathrm{~m}(2.5 \mathrm{ft})$ beneath the leachfield basement within the same trench walls. Excavations at septic tank outfalls are described in a later section of this report.

Three leachfields were discovered in SWS $2 \& 6$ during trenching activities. Because of the similarities and common routing of wastewaters, the sites are addressed collectively.

\section{A.2.3.2 Drilling}

The hollow-stem auger drilling method was selected to advance the boreholes. Twenty-one borings were conducted to collect continuous core samples at the 1965-1975 and Post-1975 Leachfields and Septic Tank 33-4. Samples were collected using a 4-inch diameter, modified-California stainless-steel split-spoon sampler at 1.5-m (5-ft) intervals and placed into the appropriate containers and submitted for analyses. The borehole locations are shown on (Figure A.2-2). No borings were conducted to investigate the Pre-1965 Leachfield.

\section{A.2.3.3 Field Screening}

Field-screening methods were used to collect qualitative data and provided a mechanism for guiding sampling. Two consecutive "clean" samples, as measured by field-screening (then confirmed through off-site laboratory analyses), defined the lower or lateral limits of the impacted soils. Field screening was performed as specified in the CAIP. The screening methods included:

- Radiological screening for alpha and beta radiation using an Electra instrument 


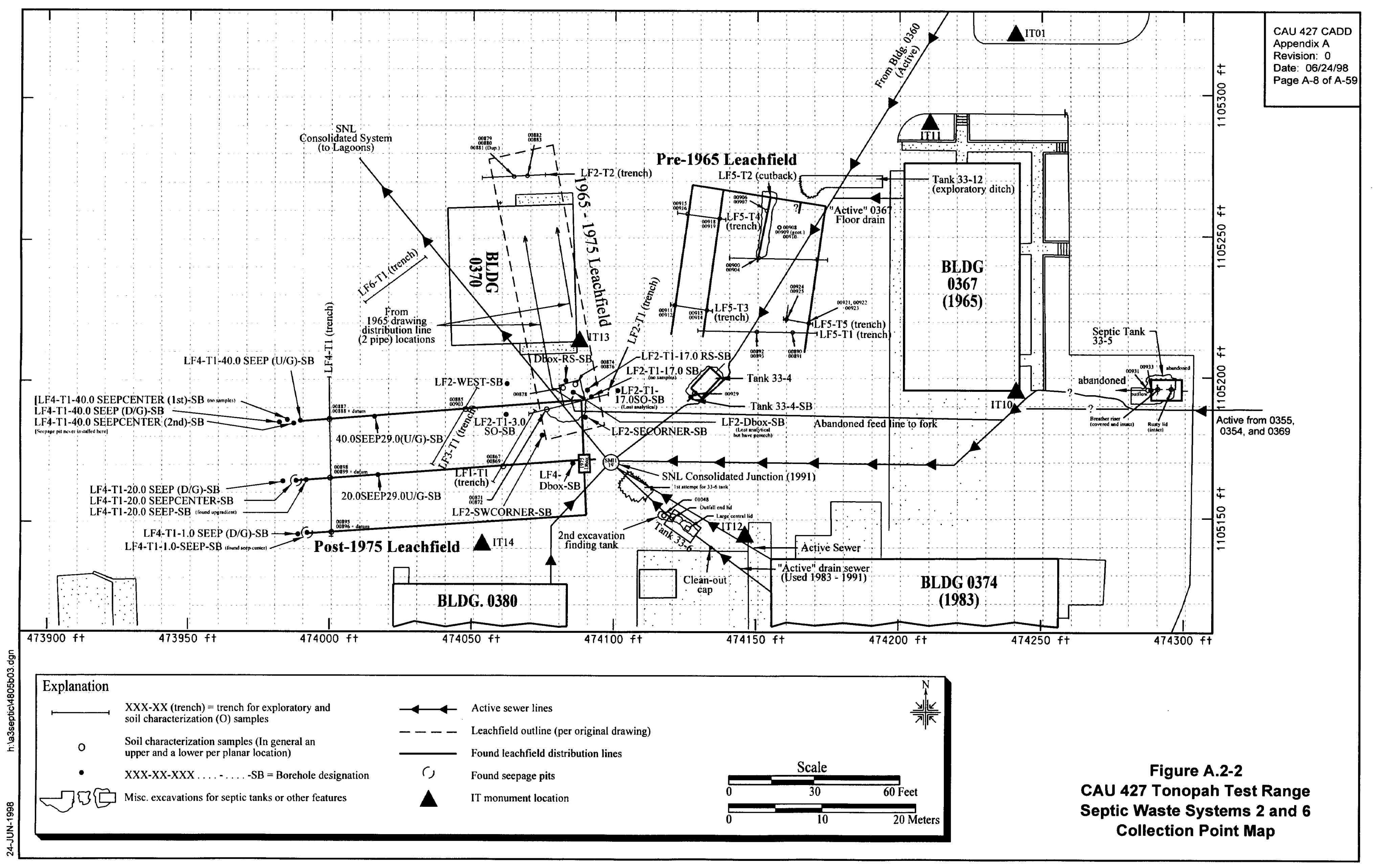


- Headspace screening for volatile organic concentrations using a Photoionization Detector

- $\quad$ TPH screening using the Hanby field testing kit manufactured by Hanby Environmental Laboratory Procedures, Inc.

The preliminary action level for TPH field-screening results was established at 100 parts per million (ppm). The preliminary action level for volatile organic concentration field-screening results was determined to be $20 \mathrm{ppm}$ or 2.5 times background, whichever was higher. The preliminary action level for radiation monitoring results was established at two times background levels (DOE/NV, 1997a). Field-screening preliminary action levels were established to guide the advancement of the borehole and to provide a basis for collecting unplanned environmental samples or drilling additional boreholes.

\section{A.2.3.4 Sample Collection}

Sample collection was performed as specified in the CAIP (DOE/NV, 1997a). The field geologist recorded geologic field descriptions on a Visual Classification of Soil Log (Appendix B) for each of the soil borings.

Soil samples were collected from individual trenches below actual or implied (in the event that the original line was destroyed) distribution lines. An upper trench interval consisted of material from

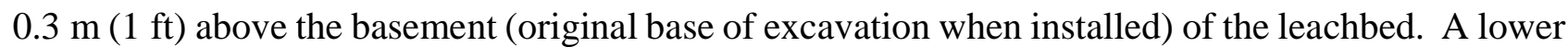
trench interval consisted of material from $0.75 \mathrm{~m}(2.5 \mathrm{ft})$ below the base of the leachbed. The number of distribution lines determined the horizontal distribution of sample collection points. Thus, if there were three distribution lines, a total of twelve samples were collected from the two trenches for a given leachfield. Soil samples were also collected underneath the outfall ends of three septic tanks and at distribution boxes or forks for the three discovered leachfields.

Soil samples were analyzed for total VOCs, total SVOCs, total RCRA Metals, PCBs, TPH, and gamma-emitting radionuclides. In addition, samples were analyzed for geotechnical parameters from in situ soils beneath the distribution box or fork for each leachfield. 


\section{A.2.3.5 Pre-1965 Leachfield (SWS 6)}

This is the earliest of the three leachfields and was installed with the apparent intent to receive liquid wastes from Building 03-60 from 1960 through 1965. This leachfield was transected in several locations and video-surveyed to reveal a five-pipe clay tile system. Investigation of a proximal end trench (LF5-T4), a trench intersecting the central distribution pipe (LF5-T2), an excavation along the central distribution line (LF5-T2-Cutback), and a "potholed" excavation at the historically reported distribution feeder (as projected from an engineering drawing) yielded environmental soil samples (and a geotechnical sample) representative of this portion of the leachfield. Three additional trenches (LF5-T1, LF5-T3, and LF5-T5) were cut at the distal end resulting in the collection of additional samples (Figure A.2-2).

A majority of the distribution network was clearly defined consisting of a five-pipe vitrified clay tile system residing in individual, narrow leachbeds comprised of 3- to 8-cm (1- to 3-in.) diameter

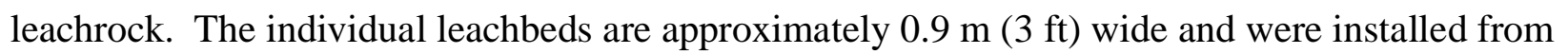
depths of 1.2 to $2.1 \mathrm{~m}$ ( 4 to $7 \mathrm{ft}$ ) below ground surface. The clay tile system is in like-new condition and has apparently never been used as evidenced by an absence of any staining or odors, the inner surface of the tiles are perfectly clean and 4-in. wood planks of redwood supporting the tiles do not show evidence of degradation. Records indicate that the leachfield is associated with Septic Tank 33-12 which was specified to be installed as an integral part of the system (DOE/NV, 1997a) (see Figure A.2-1). The intended purpose of the tank was to receive septage, then route effluent into the leachfield. An extensive exploratory ditch was excavated to intersect either a feeder/input line upgradient from the leachfield and/or the actual tank. There was no evidence of the septic tank or a feeder line (Figure A.2-2). A video survey of the entire active line from Building 03-60 showed no tie-ins, off-shoots, or other irregularities. This supports the conclusion that this septic system did not receive any discharges from Building 03-60 during this time period.

Twenty-two soil samples were collected at the Pre-1965 Leachfield, exclusive of Quality Assurance/Quality Control (QA/QC) samples. Specifically, these samples are identified by sample numbers TTR00890 through TTR00893, TTR00900, TTR00904, TTR00906 through TTR00908, TTR00910 through TTR00916, TTR00918, TTR00919, TTR00921, and TTR00923 through TTR00925. The associated geotechnical sample is identified as sample number TTR00909. No drilling was conducted at this leachfield. 


\section{A.2.3.6 1965-1975 Leachfield (SWS 2)}

This system received liquid wastes from all of the contributing SWS $2 \& 6$ discharge sources during this time period. Buildings 03-74 and 03-80 post date this installation (Figure A.2-2). Trench LF2-T1 and excavation LF2-T1-Cutback were cut to expose the proximal/distribution end of the leachfield. The location and dimensions were found as illustrated in the 1965 "as-built" engineering drawing (DOE/NV, 1997a). Recent excavations for underground utility installations, including the SNL consolidated system, have mostly disturbed this portion of the leachfield as it was originally installed. The only evidence of the two-pipe distribution lines was a fragment of $10 \mathrm{~cm}$ (4-in.) vitrified clay pipe (Figure A.2-2). A clearly defined horizontal leachbed consisting of 3- to 8-cm (1- to 3-in.) rock with a thickness ranging from 1.2 to $1.4 \mathrm{~m} \mathrm{(4} \mathrm{to} 5 \mathrm{ft}$ ) was discovered. The uppermost margin (top) of the leachbeds was found at depths ranging from 0.6 to $0.9 \mathrm{~m}$ ( 2.1 to $3 \mathrm{ft}$ ) below ground surface. The leachrock was coated with a black, dry residue in the upper portion which graded to a rust-colored staining at the base. There was some staining into the basement soil, but the basement did not seem to be greatly affected by downward percolation. Building 03-70 has been constructed directly above the leachfield; therefore, the subsurface soil near the leachfield center could not be investigated.

Trench LF2-T2 was cut at the distal end revealing a thin leachrock layer with a maximum thickness of $15 \mathrm{~cm}$ (6 in.), defining the approximate end of the leachfield. The leachrock and underlying basement at the distal end were observed to be clean with no staining or evidence of fluid input.

As specified, all soil samples were collected from within the base of the original leachfield and in situ soils from the basement underneath. The environmental soil samples collected within the two trenches and cutback excavation are identified by sample numbers: TTR00871, TTR00872, TTR00874, TTR00876, TTR00878, TTR00880, TTR00882, and TTR00883, exclusive of QA/QC samples. Two boreholes were drilled, and core samples were collected from the proximal "distribution mouth" of the leachfield to investigate the vertical extent of possible contamination. These are boreholes DBOX-RS-SB and LF2-T1-17.0RS-SB (Figure A.2-2). Step-out (outside the margins of the leachfield) boreholes to define the proximal end were also drilled and include: LF2-WEST-SB, LF2-T1-3.0SO-SB, LF2-SWCORNER-SB, and LF2-SECORNER-SB. One borehole, LF2-DBOX-SB, was also drilled to obtain a geotechnical sample (TTR00935). Analytical results are discussed in Section A.3.0 of this appendix. 


\section{A.2.3.7 Post-1975 Leachfield (SWS 2)}

This leachfield was operational until the SNL consolidated sewer upgrade effectively eliminated the discrete systems that had been in use in the Area 3 Compound (DOE/NV, 1997a). This is a three-pipe, 4-inch plastic system that received effluent originating from SWS $2 \& 6$ building drains that discharged through in-line septic tanks 33-4, 33-5, and 33-6 (Figure A.2-2). The distribution lines are each approximately $30 \mathrm{~m}(100 \mathrm{ft})$ long and the lower $21 \mathrm{~m}(70 \mathrm{ft})$ sections (downgradient) of the pipes have $1.3-\mathrm{cm}(0.5-\mathrm{in}$.) perforations. Each horizontal distribution line was installed at a depth of approximately $1.2 \mathrm{~m}$ (4 ft) and resides in a 0.6 to $0.9 \mathrm{~m}$ ( 2 to $3 \mathrm{ft})$ wide leachbed with thicknesses ranging from 0.6 to $1.4 \mathrm{~m}$ ( 2 to $4.5 \mathrm{ft}$ ). Initially, a seepage pit was located via tunneling. Further investigation and sampling at this pit and two other potential seepage pits resumed by means of continuous coring. Two of the three distribution lines were found to terminate in gravel-filled vertical seepage pits. No evidence of a third seepage pit was found.

The apparent design function of this system was for wastewaters to percolate through the distribution pipe perforations into the surrounding leachbed, with any residual fraction traveling the length of the pipe and discharging into the respective seepage pits. The majority of the perforations in the pipe were clogged with a thick, black residue indicating an increased likelihood of effluent reaching the seepage pits. This investigation revealed that a seepage pit at the northern-most line was never installed, and evidence of contamination backing up in the line supports the absence of a pit. The proximal ends of the pipes were initially exposed via trenches LF1-T1and LF3-T1 with respective sample pairs TTR00867, TTR00869; and TTR00885, TTR00903 collected. Trench LF4-T1 transected all three pipes at the distal ends and environmental soil sample numbers TTR00887, TTR00888, TTR00895, TTR00896, TTR00898, and TTR00899 were collected. All analytical results are discussed in Section A.3.0, and borehole information pertaining to this leachfield is discussed in the following paragraph.

Nine boreholes were drilled and continuously cored to investigate potential contamination of soils in the immediate vicinity of the seepage pits (Figure A.2-2). The first seepage pit investigated was associated with the southern-most pipe. Borehole LF4-T1-1.0SEEP-SB was drilled vertically through the gravel contents of the 0.9 to $1.1 \mathrm{~m}$ ( 3 to $4 \mathrm{ft}$ ) wide pit, and core samples were collected from the base at $8.9 \mathrm{~m}(29.5 \mathrm{ft})$ and appropriate depth intervals underneath. A "paired" downgradient borehole, LF4-T1-1.0SEEP(D/G)-SB, was cored through native material into the sidewall 
approximately $0.5 \mathrm{~m}(1.5 \mathrm{ft})$ outside of the pit to investigate potential migration. At the seepage pit associated with the center distribution line, a set of three boreholes, including an upgradient location, were continuously cored and sampled in the same manner. Specifically, these are LF4-T1-20.0SEEPCENTER-SB, LF4-T1-20.0SEEP-SB, and LF4-T1-20.0SEEP(D/G)-SB. The bottom of this pit was found at a depth of $6 \mathrm{~m}(20 \mathrm{ft})$. The northern-most pipe of the system was investigated by drilling four boreholes: LF4-T1-40.0SEEP(D/G)-SB,

\section{LF4-T1-40.0SEEPCENTER(1st)-SB, LF4-T1-40.0SEEPCENTER(2nd)-SB, and}

LF4-T1-40.0SEEP(U/G)-SB). The cluster of boreholes at the pipe end encountered native materials only, therefore ruling out the existence of a seepage pit associated with this pipe. Borehole

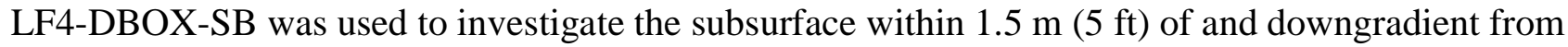
the distribution box. Geotechnical sample number TTR00967 was also collected at this location.

\section{A.2.3.8 Septic Tanks}

As stated in the CAIP, a septic tank abandonment program which included Septic Tanks 33-4, 33-5 and 33-6 was conducted in 1993 by SNL consisting of pumping out any residual liquid wastes, air drying the tanks, and filling the tanks with sand and cement (DOE/NV, 1996a). These three septic tanks were located during this investigation. Septic Tank 33-4 was found in an abandoned state, free of all liquids and completely filled with "Morrell Mix," a hard, cement-like mixture. Environmental soil sample number TTR00929 was collected at the outfall end of the tank which was breached as evidenced by hydrocarbon staining and analytical sample results. See Table A.3-1 and Section A.3.3 for additional discussion of these results. During this investigation, Septic Tank 33-5 was located and was found to be inactive, but it still contained septage. A breather/riser pipe was removed from the lid of the exposed tank, and a probe was inserted to reveal that the tank was approximately half full of septage. Environmental soil sample number TTR00933 was collected from the outfall end of the tank. Septic Tank 33-6 was uncovered along with the associated outfall pipe. The tank was found to have been filled with a coarse-grained sand which is now saturated with what appears to be water. The tank is connected to the SNL consolidated system and functions in some capacity to route liquid released from a floor drain in Building 03-74. The existing outfall pipe is modern which suggests that the original pipe was replaced during the 1991 or 1993 SNL effort. A thick layer of "Morrell Mix" has been poured on the top surface of the tank, sealing the individual central and outfall lids. There was no evidence to indicate soil contamination or breaches of the system. Environmental soil sample 
number TTR01048 was collected at a depth of 2.4 to $2.6 \mathrm{~m}$ ( 8 to $8.5 \mathrm{ft}$ ) bgs, which is below the interval of material that was placed to backfill the excavation during the 1991 activities. The collected sample is representative of soil conditions prior to 1991 activities. As previously stated, Septic Tank 33-12 has never been located or had its existence field-verified.

\section{A.2.3.9 Septic Tank 33-5 Samples}

To supplement the initial corrective action investigation activities, additional sampling activities were conducted on March 30, 1998. The purpose of these activities was to obtain environmental samples of the contents of Septic Tank 33-5.

The soil above Septic Tank 33-5 was excavated to expose the vent pipes and the manhole cover to the tank. The manhole cover was removed and two samples were obtained from the waste within the tank. A liquid sample, sample number TTR-335-1, was collected and analyzed for VOCs and TPH. Due to the limited amount of liquid medium, no other analytical methods were performed on this sample. A solid sample, sample number TTR-335-2, was collected and analyzed for VOCs, SVOCs, Pesticides, TCLP Metals and TPH. These samples were analyzed by NEL Laboratories in Las Vegas, Nevada.

\section{A.2.4 Geology}

The surface at the SWS $2 \& 6$ site consists of reworked and compacted gravels and sands with native soils underneath. Regional native surface deposits consist of well-sorted, moderately consolidated alluvial silty sands with gravel and cobble-sized volcanic detritus (DOE/NV, 1996a). The IT field geologist recorded field descriptions for each boring and recorded on Visual Classification of Soil Logs (Appendix B).

\section{A.2.5 Hydrology}

The Area 3 topography slopes gently to the northwest with surface drainage flowing in the same direction. Depth to groundwater beneath SWS 2 \& 6 is estimated at 110 to $120 \mathrm{~m}$ (361 to $394 \mathrm{ft}$ ) bgs (DOE/NV, 1996a). No perched water, any indication of recent liquid input, or saturated materials were found in the subsurface at the SWS 2 \& 6 site. 


\section{A.3.0 Investigation Results}

The analytical results of samples collected from the Area 3 SWS 2 \& 6 CAU have been compiled and evaluated to determine the presence and/or extent of contamination. The analytical results are summarized in the following subsections. The complete laboratory results data packages are available in the project files.

During the investigation activities, 120 soil sample sets and 14 liquid samples were collected for laboratory analysis. Three soil samples were collected for geotechnical analysis. A list of the sample numbers (including field duplicate and other quality control samples) and their relationship to the boreholes is presented in Table A.3-1. The analytical parameters and laboratory analytical methods

Table A.3-1

Samples Collected During the Area 3 SWS 2 \& 6 Corrective Action Investigation Activities

(Page 1 of 7 )

\begin{tabular}{|c|c|c|c|}
\hline Borehole/Trench Name & Sample Number & $\begin{array}{c}\text { Depth } \\
\text { (feet bgs) }\end{array}$ & Sample Type \\
\hline \multicolumn{4}{|c|}{ Post-1975 Leachfield } \\
\hline \multirow{3}{*}{ Pre-startup } & TTR00864 & $\mathrm{n} / \mathrm{a}$ & Trip Blank \\
\hline & TTR00865 & $\mathrm{n} / \mathrm{a}$ & Equipment Rinsate Blank \\
\hline & TTR00866 & $\mathrm{n} / \mathrm{a}$ & Field Blank \\
\hline \multirow{3}{*}{ LF1-T1 } & TTR00867 & $4.3-4.6$ & Soil \\
\hline & TTR00868 & $\mathrm{n} / \mathrm{a}$ & Trip Blank \\
\hline & TTR00869 & $9.5-9.8$ & Soil \\
\hline \multirow{8}{*}{ LF4-T1 } & TTR00887 & $5.0-6.0$ & Soil \\
\hline & TTR00888 & $8.5-9.0$ & Soil \\
\hline & TTR00889 & $\mathrm{n} / \mathrm{a}$ & Trip Blank \\
\hline & TTR00895 & $8.5-9.0$ & Soil \\
\hline & TTR00896 & $11.0-12.0$ & Soil \\
\hline & TTR00897 & $11.0-12.0$ & Duplicate of TTR00896 \\
\hline & TTR00898 & $6.5-7.0$ & MS/MSD \\
\hline & TTR00899 & $9.0-9.5$ & Soil \\
\hline
\end{tabular}


Table A.3-1

Samples Collected During the Area 3 SWS 2 \& 6 Corrective Action Investigation Activities

(Page 2 of 7 )

\begin{tabular}{|c|c|c|c|}
\hline Borehole/Trench Name & Sample Number & $\begin{array}{c}\text { Depth } \\
\text { (feet bgs) }\end{array}$ & Sample Type \\
\hline \multirow{5}{*}{ LF3-T1 } & TTR00885 & $4.5-5.5$ & MS/MSD \\
\hline & TTR00886 & $\mathrm{n} / \mathrm{a}$ & Trip Blank \\
\hline & TTR00901 & $\mathrm{n} / \mathrm{a}$ & Equipment Rinsate Blank \\
\hline & TTR00902 & $\mathrm{n} / \mathrm{a}$ & Field Blank \\
\hline & TTR00903 & $9.0-10.0$ & Soil \\
\hline \multirow{4}{*}{ LF4-DBOX-SB } & TTR00966 & $6.5-7.5$ & Soil \\
\hline & TTR00967 & $8.0-9.0$ & Geotechnical \\
\hline & TTR00968 & $10.0-12.5$ & Soil \\
\hline & TTR00969 & $15.0-17.5$ & Soil \\
\hline \multirow{5}{*}{ LF4-T1-1.0SEEP-SB } & TTR00970 & $30.0-32.5$ & Soil \\
\hline & TTR00971 & $35.0-37.5$ & Soil \\
\hline & TTR00972 & $40.0-42.5$ & Soil \\
\hline & TTR00973 & $\mathrm{n} / \mathrm{a}$ & Trip Blank \\
\hline & TTR00974 & $40.0-42.5$ & Duplicate of TTR00972 \\
\hline \multirow{6}{*}{ LF4-T1-20.0SEEP-SB } & TTR00975 & $7.5-10.0$ & Soil \\
\hline & TTR00976 & $\mathrm{n} / \mathrm{a}$ & Trip Blank \\
\hline & TTR00977 & $\mathrm{n} / \mathrm{a}$ & Equipment Rinsate \\
\hline & TTR00978 & $\mathrm{n} / \mathrm{a}$ & Field Blank \\
\hline & TTR00979 & $20.0-22.5$ & $\mathrm{MS} / \mathrm{MSD}$ \\
\hline & TTR00980 & $25.0-27.5$ & Soil \\
\hline \multirow{9}{*}{ LF4-T1-20.0SEEP(D/G)-SB } & TTR00981 & $\mathrm{n} / \mathrm{a}$ & Trip Blank \\
\hline & TTR00982 & $5.0-7.5$ & Soil \\
\hline & TTR00983 & $10.0-12.5$ & Soil \\
\hline & TTR00984 & $15.0-17.5$ & Soil \\
\hline & TTR00985 & $20.0-22.5$ & Soil \\
\hline & TTR00986 & $25.0-27.5$ & Soil \\
\hline & TTR00987 & $30.0-32.5$ & Soil \\
\hline & TTR00988 & $35.0-37.5$ & Soil \\
\hline & TTR00989 & $\mathrm{n} / \mathrm{a}$ & Trip Blank \\
\hline
\end{tabular}


Table A.3-1

Samples Collected During the Area 3 SWS $2 \& 6$ Corrective Action Investigation Activities

(Page 3 of 7 )

\begin{tabular}{|c|c|c|c|}
\hline Borehole/Trench Name & Sample Number & $\begin{array}{c}\text { Depth } \\
\text { (feet bgs) }\end{array}$ & Sample Type \\
\hline \multirow{7}{*}{ LF4-T1-40.0SEEP(U/G)-SB } & TTR00990 & $10.0-12.5$ & Soil \\
\hline & TTR00991 & $15.0-17.5$ & Soil \\
\hline & TTR00992 & $20.0-22.5$ & Soil \\
\hline & TTR00993 & $25.0-27.5$ & Soil \\
\hline & TTR00994 & $33.5-35.0$ & Soil \\
\hline & TTR00995 & $40.0-42.5$ & Soil \\
\hline & TTR00996 & $\mathrm{n} / \mathrm{a}$ & Trip Blank \\
\hline \multirow{2}{*}{ 40.0SEEP-29.0(U/G)-SB } & TTR00997 & $7.5-10.0$ & Soil \\
\hline & TTR00998 & $12.5-15.0$ & Soil \\
\hline \multirow{3}{*}{ 20.0SEEP-29.0(U/G)-SB } & TTR00999 & $7.5-10.0$ & Soil \\
\hline & TTR01000 & $12.5-15.0$ & Soil \\
\hline & TTR01001 & $\mathrm{n} / \mathrm{a}$ & Trip Blank \\
\hline \multirow{4}{*}{$\begin{array}{l}\text { LF4-T1-20.0SEEP } \\
\text { CENTER-SB }\end{array}$} & TTR01012 & $20.0-22.5$ & Soil \\
\hline & TTR01013 & $25.0-26.0$ & Soil \\
\hline & TTR01014 & $30.0-32.5$ & $\mathrm{MS} / \mathrm{MSD}$ \\
\hline & TTR01015 & $35.0-37.5$ & Soil \\
\hline \multirow{13}{*}{ LF4-T1-40.0SEEP(D/G)-SB } & TTR01016 & $7.5-10.0$ & Soil \\
\hline & TTR01017 & $12.5-15.0$ & Soil \\
\hline & TTR01018 & $17.5-20.0$ & Soil \\
\hline & TTR01019 & $17.5-20.0$ & Duplicate of TTR01018 \\
\hline & TTR01020 & $22.5-25.0$ & Soil \\
\hline & TTR01021 & $27.5-30.0$ & Soil \\
\hline & TTR01022 & $32.5-35.0$ & Soil \\
\hline & TTR01023 & $\mathrm{n} / \mathrm{a}$ & Trip Blank \\
\hline & TTR01024 & $37.5-40.0$ & Soil \\
\hline & TTR01025 & $n / a$ & Trip Blank \\
\hline & TTR01026 & $n / a$ & Trip Blank \\
\hline & TTR01027 & $\mathrm{n} / \mathrm{a}$ & Field Blank \\
\hline & TTR01028 & $\mathrm{n} / \mathrm{a}$ & Equipment Rinsate \\
\hline
\end{tabular}


Table A.3-1

Samples Collected During the Area 3 SWS 2 \& 6 Corrective Action Investigation Activities

(Page 4 of 7 )

\begin{tabular}{|c|c|c|c|}
\hline Borehole/Trench Name & Sample Number & $\begin{array}{c}\text { Depth } \\
\text { (feet bgs) }\end{array}$ & Sample Type \\
\hline \multirow{8}{*}{$\begin{array}{l}\text { LF4-T1-40.0SEEP } \\
\text { CENTER(2nd)-SB }\end{array}$} & TTR01029 & $15.0-17.5$ & Soil \\
\hline & TTR01030 & $20.0-22.5$ & Soil \\
\hline & TTR01031 & $25.0-27.5$ & Soil \\
\hline & TTR01032 & $31.5-34.0$ & Soil \\
\hline & TTR01033 & $36.5-39.0$ & Soil \\
\hline & TTR01034 & $n / a$ & Trip Blank \\
\hline & TTR01035 & $41.5-44.0$ & Soil \\
\hline & TTR01036 & $41.5-44.0$ & Duplicate of TTR01035 \\
\hline \multirow{10}{*}{ LF4-T1-1.0SEEP(D/G)-SB } & TTR01037 & $\mathrm{n} / \mathrm{a}$ & Trip Blank \\
\hline & TTR01038 & $5.0-7.5$ & Soil \\
\hline & TTR01039 & $10.0-12.5$ & $\mathrm{MS} / \mathrm{MSD}$ \\
\hline & TTR01040 & $15.0-17.5$ & Soil \\
\hline & TTR01041 & $20.0-22.5$ & Soil \\
\hline & TTR01042 & $25.0-27.5$ & Soil \\
\hline & TTR01043 & $30.0-32.5$ & Soil \\
\hline & TTR01044 & $35.0-37.5$ & Soil \\
\hline & TTR01045 & $40.0-42.5$ & Soil \\
\hline & TTR01046 & $\mathrm{n} / \mathrm{a}$ & Trip Blank \\
\hline \multicolumn{4}{|c|}{ 1965-1975 Leachfield } \\
\hline \multirow{8}{*}{$\begin{array}{c}\text { LF2-T1 \& } \\
\text { LF2-T1-CUTBACK }\end{array}$} & TTR00870 & $\mathrm{n} / \mathrm{a}$ & Trip Blank \\
\hline & TTR00871 & $5.0-5.5$ & Soil \\
\hline & TTR00872 & $7.2-7.7$ & Soil \\
\hline & TTR00873 & $\mathrm{n} / \mathrm{a}$ & Trip Blank \\
\hline & TTR00874 & $5.0-6.0$ & Soil \\
\hline & TTR00876 & $7.5-8.0$ & Soil \\
\hline & TTR00877 & $\mathrm{n} / \mathrm{a}$ & Trip Blank \\
\hline & TTR00878 & $9.5-10.0$ & Soil \\
\hline
\end{tabular}


Table A.3-1

Samples Collected During the Area 3 SWS 2 \& 6 Corrective Action Investigation Activities

(Page 5 of 7 )

\begin{tabular}{|c|c|c|c|}
\hline Borehole/Trench Name & Sample Number & $\begin{array}{c}\text { Depth } \\
\text { (feet bgs) }\end{array}$ & Sample Type \\
\hline \multirow{6}{*}{ LF2-T2 } & TTR00879 & $3.5-4.0$ & Soil \\
\hline & TTR00880 & $6.5-7.5$ & Soil \\
\hline & TTR00881 & $6.5-7.5$ & Duplicate of TTR00880 \\
\hline & TTR00882 & $3.5-4.0$ & Soil \\
\hline & TTR00883 & $6.5-7.5$ & Soil \\
\hline & TTR00884 & $n / a$ & Trip Blank \\
\hline LF2-DBOX-SB & TTR00935 & $6.0-7.5$ & Geotechnical \\
\hline \multirow{3}{*}{ Tank-33-4-SB } & TTR00945 & $7.5-10.0$ & Soil \\
\hline & TTR00946 & $12.5-14.5$ & Soil \\
\hline & TTR00947 & $\mathrm{n} / \mathrm{a}$ & Trip Blank \\
\hline \multirow{4}{*}{ LF2-SECORNER-SB } & TTR00948 & $7.5-10.0$ & MS/MSD \\
\hline & TTR00949 & $12.5-15.0$ & Soil \\
\hline & TTR00950 & $12.5-15.0$ & Duplicate of TTR00949 \\
\hline & TTR00951 & $17.5-20.0$ & Soil \\
\hline \multirow{6}{*}{ LF2-T1-3.0-SO-SB } & TTR00952 & $\mathrm{n} / \mathrm{a}$ & Trip Blank \\
\hline & TTR00953 & $\mathrm{n} / \mathrm{a}$ & Field Blank \\
\hline & TTR00954 & $\mathrm{n} / \mathrm{a}$ & Equipment Rinsate \\
\hline & TTR00955 & $7.5-10.0$ & Soil \\
\hline & TTR00956 & $12.5-15.0$ & Soil \\
\hline & TTR00957 & $17.5-20.0$ & Soil \\
\hline \multirow{4}{*}{ LF2-WEST-SB } & TTR00958 & $\mathrm{n} / \mathrm{a}$ & Trip Blank \\
\hline & TTR00959 & $5.0-7.5$ & Soil \\
\hline & TTR00960 & $10.0-12.5$ & Soil \\
\hline & TTR00961 & $15.0-17.5$ & Soil \\
\hline \multirow{4}{*}{ LF2- SWCORNER-SB } & TTR00962 & $5.0-7.5$ & Soil \\
\hline & TTR00963 & $10.0-12.5$ & Soil \\
\hline & TTR00964 & $15.0-17.5$ & Soil \\
\hline & TTR00965 & $\mathrm{n} / \mathrm{a}$ & Trip Blank \\
\hline
\end{tabular}


Table A.3-1

Samples Collected During the Area 3 SWS 2 \& 6 Corrective Action Investigation Activities

(Page 6 of 7)

\begin{tabular}{|c|c|c|c|}
\hline Borehole/Trench Name & Sample Number & $\begin{array}{c}\text { Depth } \\
\text { (feet bgs) }\end{array}$ & Sample Type \\
\hline \multirow{6}{*}{ DBOX-RS-SB } & TTR01002 & $7.5-10.0$ & Soil \\
\hline & TTR01003 & $\mathrm{n} / \mathrm{a}$ & Field Blank \\
\hline & TTR01004 & $17.5-19.0$ & Soil \\
\hline & TTR01005 & $\mathrm{n} / \mathrm{a}$ & Trip Blank \\
\hline & TTR01006 & $n / a$ & Equipment Rinsate \\
\hline & TTR01007 & $22.5-25.0$ & Soil \\
\hline \multirow{4}{*}{ LF2-T1-17.0-RS-SB } & TTR01008 & $7.5-10.0$ & Soil \\
\hline & TTR01009 & $15.0-17.5$ & Soil \\
\hline & TTR01010 & $20.0-22.5$ & Soil \\
\hline & TTR01011 & $\mathrm{n} / \mathrm{a}$ & Trip Blank \\
\hline \multicolumn{4}{|c|}{ Pre-1965 Leachfield } \\
\hline \multirow{5}{*}{ LF5-T1 } & TTR00890 & $5.0-6.0$ & Soil \\
\hline & TTR00891 & $8.5-9.0$ & Soil \\
\hline & TTR00892 & $5.0-6.0$ & Soil \\
\hline & TTR00893 & $8.5-9.0$ & Soil \\
\hline & TTR00894 & $\mathrm{n} / \mathrm{a}$ & Trip Blank \\
\hline \multirow{3}{*}{ LF5-T2 } & TTR00900 & $5.0-6.0$ & Soil \\
\hline & TTR00904 & $9.5-10.0$ & Soil \\
\hline & TTR00905 & $n / a$ & Trip Blank \\
\hline \multirow{2}{*}{ LF5-T2-CUTBACK } & TTR00906 & $6.5-7.0$ & Soil \\
\hline & TTR00907 & $9.5-10.0$ & Soil \\
\hline \multirow{3}{*}{ LF5-DBOX } & TTR00908 & $7.5-8.0$ & Soil \\
\hline & TTR00909 & $7.0-8.0$ & Geotechnical \\
\hline & TTR00910 & $9.5-10.0$ & Soil \\
\hline \multirow{4}{*}{ LF5-T3 } & TTR00911 & $6.0-7.0$ & Soil \\
\hline & TTR00912 & $9.0-10.0$ & Soil \\
\hline & TTR00913 & $6.5-7.0$ & Soil \\
\hline & TTR00914 & $9.0-10.0$ & Soil \\
\hline
\end{tabular}


Table A.3-1

Samples Collected During the Area 3 SWS 2 \& 6 Corrective Action Investigation Activities

(Page 7 of 7 )

\begin{tabular}{|c|c|c|c|}
\hline Borehole/Trench Name & Sample Number & $\begin{array}{c}\text { Depth } \\
\text { (feet bgs) }\end{array}$ & Sample Type \\
\hline \multirow{6}{*}{ LF5-T4 } & TTR00915 & $7.5-8.0$ & Soil \\
\hline & TTR00916 & $9.5-10.0$ & Soil \\
\hline & TTR00917 & $\mathrm{n} / \mathrm{a}$ & Trip Blank \\
\hline & TTR00918 & $6.5-7.0$ & Soil \\
\hline & TTR00919 & $9.5-10.0$ & Soil \\
\hline & TTR00920 & $\mathrm{n} / \mathrm{a}$ & Trip Blank \\
\hline \multirow{8}{*}{ LF5-T5 } & TTR00921 & $6.5-7.0$ & MS/MSD \\
\hline & TTR00922 & $9.5-10.0$ & Soil \\
\hline & TTR00923 & $9.5-10.0$ & Duplicate of TTR00922 \\
\hline & TTR00924 & $6.5-7.0$ & Soil \\
\hline & TTR00925 & $9.0-9.5$ & Soil \\
\hline & TTR00926 & $\mathrm{n} / \mathrm{a}$ & Field Blank \\
\hline & TTR00927 & $\mathrm{n} / \mathrm{a}$ & Equipment Rinsate \\
\hline & TTR00928 & $n / a$ & Trip Blank \\
\hline \multicolumn{4}{|c|}{ Septic Tanks } \\
\hline \multirow{2}{*}{$33-4$} & TTR00928 & $\mathrm{n} / \mathrm{a}$ & Trip Blank \\
\hline & TTR00929 & $4.5-5.0$ & Soil \\
\hline \multirow{2}{*}{$33-5$} & TTR00932 & $\mathrm{n} / \mathrm{a}$ & Trip Blank \\
\hline & TTR00931 \& TTR00933 & $7.1-7.4$ & Soil/Soil \\
\hline \multirow{2}{*}{$33-6$} & TTR01047 & $\mathrm{n} / \mathrm{a}$ & Trip Blank \\
\hline & TTR01048 & $8.0-8.5$ & Soil \\
\hline
\end{tabular}

requested for this investigation are presented in Table A.3-2. The analytical parameters were selected through the application of site process knowledge according to the EPA's Guidance for the Data Quality Objectives Process (EPA, 1994a). Preliminary action levels for off-site laboratory analytical methods were determined during the DQO process and are based on the EPA Region 9 Preliminary Remediation Goals (PRGs) (EPA, 1996a) for chemical parameters and either background levels or levels listed in the Offsite Radiation Exposure Review Project Phase II Soil Programs report (McArthur and Miller, 1989) for radiological constituents. The results of the DQO process are 
Table A.3-2

Laboratory Analytical Methods Used for

Area 3 SWS 2 \& 6 Investigation Samples

\begin{tabular}{|c|c|}
\hline Analytical Parameter & Analytical Method \\
\hline Total volatile organic compounds & EPA $8260^{\mathrm{a}}$ \\
\hline Total petroleum hydrocarbons - gasoline and diesel/oil & EPA 8015 (modified) ${ }^{a}$ \\
\hline Total semivolatile organic compounds & EPA $8270^{\mathrm{a}}$ \\
\hline $\begin{array}{l}\text { Total RCRA metals (arsenic, barium, cadmium, chromium, lead, selenium, silver, and } \\
\text { mercury) }\end{array}$ & EPA $6010 / 7470^{a}$ \\
\hline Total polychlorinated biphenyls & EPA $8080^{\mathrm{a}}$ \\
\hline Gamma Spectroscopy & HASL $300,4.5 .2 .3^{b}$ \\
\hline Geotechnical Requirements & Method \\
\hline Initial moisture content & ASTM $^{C} D 2216$ \\
\hline Dry bulk content & $E^{\mathrm{d}} 1110-2-1906$ \\
\hline Calculated porosity & $E M^{d}-1110-2-1906$ \\
\hline Saturated/unsaturated hydraulic conductivity & ASTM $^{C} D 5084$ \\
\hline Particle-size distribution & ASTM $^{C}$ D 422 \\
\hline Atterberg limits & ASTM $^{C}$ D 4318-93 \\
\hline Moisture retention characteristics & ASTM $^{C}$ D 3152 \\
\hline
\end{tabular}

a EPA Test Methods for Evaluating Solid Waste, 3rd Edition, Parts 1-4, SW-846 (EPA, 1996b)

b Environmental Measurements Laboratory Procedures Manual, HASL-300, U.S. Department of Energy (DOE, 1992)

"Annual Book of American Society for Testing and Materials (ASTM) Standards, Section 4, "Construction", Volume 04.08,

"Soil and Rock (1)", and Volume 04.09, "Soil and Rock (11)", 1996

d United States Army Corps of Engineers (USACE), Engineer Manual 1110-2-1906, "Laboratory Soils Testing," Appendix II, 1970

documented in the CAIP (DOE/NV, 1997a) with the remainder of the documentation retained in the IT Corporation (IT) project files. Sampling activities were conducted to either confirm or disprove the assumptions made in the DQO process. Samples collected from the SWS 2 \& 6 CAU were analyzed by Quanterra Environmental Services in St. Louis, Missouri. The geotechnical samples were analyzed by Converse Consultants Southwest, Inc., in Las Vegas, Nevada.

\section{A.3.1 Total Volatile Organic Compound Analytical Results}

The total VOC analytical results above minimum reporting limits established in the CAIP (DOE/NV, 1997a), along with the associated preliminary action levels, are presented in Table A.3-3. 
Table A.3-3

Soil Sample Results for Total Volatile Organic Compounds Detected Above Minimum Reporting Limits, Area 3 SWS 2 \& 6, TTR (Page 1 of 2)

\begin{tabular}{|c|c|c|c|c|c|c|c|c|}
\hline \multirow{3}{*}{$\begin{array}{l}\text { Sample Location/ } \\
\text { Borehole }\end{array}$} & \multirow{3}{*}{$\begin{array}{c}\text { Sample Number } \\
\text { Preliminary Action } \\
\text { Levels }(\mu \mathrm{g} / \mathrm{kg}) \\
\text { (Industrial Soil }^{\text {PRG) }}\end{array}$} & \multirow{3}{*}{$\begin{array}{l}\text { Sample Depth } \\
\text { (ft bgs) }\end{array}$} & \multicolumn{6}{|c|}{$\begin{array}{c}\text { Constituents of Concern } \\
\text { in micrograms per kilogram }(\mu \mathrm{g} / \mathrm{kg})\end{array}$} \\
\hline & & & Acetone & 2-Butanone & $\begin{array}{l}\text { Carbon } \\
\text { Tetrachloride }\end{array}$ & $\begin{array}{l}1,1,2,2-\text { Tetra- } \\
\text { chloroethane }\end{array}$ & $\begin{array}{l}\text { Methylene } \\
\text { Chloride }\end{array}$ & $\begin{array}{c}\text { Xylene } \\
\text { (total) }\end{array}$ \\
\hline & & & $8,800,000$ & $27,000,000$ & 500 & 1,100 & 18,000 & 320,000 \\
\hline $\begin{array}{c}\text { LF2-T1 \& } \\
\text { LF2-T1-CUTBACK }\end{array}$ & TTR00874 & 6.0 & $36(\mathrm{~J})$ & $5(\mathrm{~J})$ & -- & -- & -- & -- \\
\hline \multirow{4}{*}{ LF5-T1 } & TTR00890 & 6.0 & -- & -- & -- & -- & 13 & -- \\
\hline & TTR00891 & 9.0 & -- & -- & -- & -- & 12 & -- \\
\hline & TTR00892 & 6.0 & 21 & -- & -- & 6 & 8 & -- \\
\hline & TTR00893 & 9.0 & $18(\mathrm{~J})$ & -- & -- & -- & 7 & -- \\
\hline \multirow{5}{*}{ LF4-T1 } & TTR00895 & 9.0 & $15(\mathrm{~J})$ & -- & -- & -- & -- & -- \\
\hline & TTR00896 & 12.0 & 21 & -- & -- & -- & -- & -- \\
\hline & TTR00897 & 12.0 & 30 & -- & -- & -- & -- & -- \\
\hline & TTR00898 & 7.0 & 32 & -- & -- & -- & -- & -- \\
\hline & TTR00899 & 9.5 & $17(\mathrm{~J})$ & $9(\mathrm{~J})$ & -- & -- & -- & -- \\
\hline LF5-T2 & TTR00900 & 7.0 & $14(\mathrm{~J})$ & -- & -- & -- & -- & -- \\
\hline LF3-T1 & TTR00903 & 10.0 & $18(\mathrm{~J})$ & -- & -- & -- & -- & -- \\
\hline LF5-T2 & TTR00904 & 10.0 & $10(\mathrm{~J})$ & -- & -- & -- & -- & -- \\
\hline LF5-DBOX & TTR00908 & 8.0 & $13(\mathrm{~J})$ & $17(\mathrm{~J})$ & -- & -- & -- & -- \\
\hline LF5-DBOX & TTR00910 & 10.0 & 34 & -- & -- & -- & -- & -- \\
\hline \multirow{4}{*}{ LF5-T3 } & TTR00911 & 7.0 & $18(\mathrm{~J})$ & -- & -- & -- & -- & -- \\
\hline & TTR00912 & 10.0 & $8(\mathrm{~J})$ & 16 & -- & -- & -- & -- \\
\hline & TTR00913 & 7.0 & $18(\mathrm{~J})$ & -- & -- & -- & -- & -- \\
\hline & TTR00914 & 10.0 & $12(\mathrm{~J})$ & -- & -- & -- & -- & -- \\
\hline \multirow{4}{*}{ LF5-T4 } & TTR00915 & 8.0 & $48(\mathrm{~J})$ & -- & -- & -- & $8(\mathrm{~J})$ & -- \\
\hline & TTR00916 & 10.0 & $15(\mathrm{~J})$ & -- & -- & -- & -- & -- \\
\hline & TTR00918 & 7.0 & 22 & -- & -- & 6 & -- & -- \\
\hline & TTR00919 & 10.0 & $13(\mathrm{~J})$ & -- & -- & -- & -- & -- \\
\hline \multirow{3}{*}{ LF5-T5 } & TTR00922 & 10.0 & 50 & -- & -- & -- & -- & -- \\
\hline & TTR00923 & 10.0 & 60 & -- & -- & -- & -- & -- \\
\hline & TTR00924 & 7.0 & -- & -- & -- & -- & -- & 8 \\
\hline
\end{tabular}

aU.S. Environmental Protection Agency, Region 9 Preliminary Remediation Goals (PRGs) (EPA, 1996a) -- Not detected above the minimum reporting levels specified in the CAIP (DOE/NV, 1997a).

$\mu \mathrm{g} / \mathrm{kg}=\operatorname{Microgram}(\mathrm{s})$ per kilogram

$(\mathrm{J})=$ Estimated value 
Table A.3-3

Soil Sample Results for Total Volatile Organic Compounds Detected Above Minimum Reporting Limits, Area 3 SWS 2 \& 6, TTR (Page 2 of 2)

\begin{tabular}{|c|c|c|c|c|c|c|c|c|}
\hline \multirow{3}{*}{$\begin{array}{l}\text { Sample Location/ } \\
\text { Borehole }\end{array}$} & \multirow{3}{*}{$\begin{array}{c}\text { Sample Number } \\
\text { Preliminary Action } \\
\text { Levels }(\mu \mathrm{g} / \mathrm{kg}) \\
\text { (Industrial Soil }^{\text {PRG) }}\end{array}$} & \multirow{3}{*}{$\begin{array}{c}\text { Sample Depth } \\
\text { (ft bgs) }\end{array}$} & \multicolumn{6}{|c|}{$\begin{array}{c}\text { Constituents of Concern } \\
\text { in micrograms per kilogram }(\mu \mathrm{g} / \mathrm{kg})\end{array}$} \\
\hline & & & Acetone & 2-Butanone & $\begin{array}{c}\text { Carbon } \\
\text { Tetrachloride }\end{array}$ & $\begin{array}{l}\text { 1, 1, 2, 2-Tetra- } \\
\text { chloroethane }\end{array}$ & $\begin{array}{c}\text { Methylene } \\
\text { Chloride }\end{array}$ & $\begin{array}{c}\text { Xylene } \\
\text { (total) }\end{array}$ \\
\hline & & & $8,800,000$ & $27,000,000$ & 500 & 1,100 & 18,000 & 320,000 \\
\hline Tank 33-5 & TTR00933 & 8.0 & -- & $6(\mathrm{~J})$ & -- & -- & -- & -- \\
\hline Tank 33-4-SB & TTR00945 & 10.0 & $48(\mathrm{~J})$ & -- & -- & -- & -- & -- \\
\hline \multirow{2}{*}{ LF4-DBOX-SB } & TTR00966 & 7.5 & $27(\mathrm{~J})$ & -- & -- & -- & -- & -- \\
\hline & TTR00969 & 17.5 & -- & -- & -- & -- & 46 & -- \\
\hline LF4-T1-1.0SEEP-SB & TTR00970 & 32.5 & -- & -- & -- & -- & 38 & -- \\
\hline \multirow{3}{*}{ LF4-T1-20.0SEEP-SB } & TTR00975 & 10.0 & 23 & -- & -- & -- & -- & -- \\
\hline & TTR00979 & 22.5 & -- & -- & -- & -- & 42 & -- \\
\hline & TTR00980 & 27.5 & -- & $7(\mathrm{~J})$ & $5(\mathrm{~J})$ & -- & -- & -- \\
\hline \multirow{7}{*}{$\begin{array}{l}\text { LF4-T1-20.0SEEP } \\
\text { (D/G)SB }\end{array}$} & TTR00982 & 7.5 & 23 & -- & -- & -- & -- & -- \\
\hline & TTR00983 & 12.5 & 22 & -- & -- & -- & -- & -- \\
\hline & TTR00984 & 17.5 & 49 & $10(\mathrm{~J})$ & -- & -- & -- & -- \\
\hline & TTR00985 & 22.5 & 32 & -- & -- & -- & -- & -- \\
\hline & TTR0986 & 27.5 & 40 & -- & -- & -- & -- & -- \\
\hline & TTR00987 & 32.5 & $14(\mathrm{~J})$ & -- & -- & -- & -- & -- \\
\hline & TTR00988 & 37.5 & -- & $7(\mathrm{~J})$ & -- & -- & -- & -- \\
\hline $\begin{array}{l}\text { 40.0SEEP-29.0 } \\
(\mathrm{U} / \mathrm{G})-\mathrm{SB}\end{array}$ & TTR00997 & 10.0 & $13(\mathrm{~J})$ & -- & -- & -- & -- & -- \\
\hline $\begin{array}{l}\text { 20.0SEEP-29.0 } \\
(\mathrm{U} / \mathrm{G})-\mathrm{SB}\end{array}$ & TTR01000 & 15.0 & $13(\mathrm{~J})$ & $6(\mathrm{~J})$ & -- & -- & -- & -- \\
\hline \multirow{2}{*}{$\begin{array}{l}\text { LF4-T1-20.0SEEP } \\
\text { CENTER-SB }\end{array}$} & TTR01012 & 22.5 & $9(\mathrm{~J})$ & -- & -- & -- & -- & -- \\
\hline & TTR01015 & 37.5 & $8(J)$ & -- & -- & -- & -- & -- \\
\hline $\begin{array}{l}\text { LF4-T1-40.0SEEP } \\
\text { CENTER(2nd)-SB }\end{array}$ & TTR01032 & 34.0 & -- & $6(\mathrm{~J})$ & -- & -- & -- & -- \\
\hline \multirow{5}{*}{$\begin{array}{l}\text { LF4-T1-1.0SEEP } \\
\text { (D/G)-SB }\end{array}$} & TTR01038 & 7.5 & -- & $7(\mathrm{~J})$ & -- & -- & -- & -- \\
\hline & TTR01039 & 12.5 & -- & $5(\mathrm{~J})$ & -- & -- & -- & -- \\
\hline & TTR01040 & 17.5 & -- & $5(\mathrm{~J})$ & -- & -- & -- & -- \\
\hline & TTR01041 & 22.5 & -- & $5(\mathrm{~J})$ & -- & -- & -- & -- \\
\hline & TTR01045 & 42.5 & -- & $6(\mathrm{~J})$ & -- & -- & -- & -- \\
\hline
\end{tabular}

aU.S. Environmental Protection Agency, Region 9 Preliminary Remediation Goals (PRGs) (EPA, 1996a)

-- Not detected above the minimum reporting levels specified in the CAIP (DOE/NV, 1997a).

$\mu \mathrm{g} / \mathrm{kg}=$ Microgram(s) per kilogram

$(\mathrm{J})=$ Estimated value 
Scrutiny of the laboratory data indicates that constituents were either not present above the minimum reporting limits (DOE/NV, 1997a) or, if present, were present below the preliminary action levels. Low levels of acetone, 2-butanone, and methylene chloride were detected above minimum reporting limits (DOE/NV, 1997a), but below the preliminary action levels. These constituents are common laboratory contaminants. In addition, acetone detects were noted in two water (trip blank) samples at respective concentrations of 40 micrograms per liter $(\mu \mathrm{g} / \mathrm{L})$ and $32 \mu \mathrm{g} / \mathrm{L}$ in sample numbers TTR01023 and TTR01026; 1,1,2,2-Tetrachloroethane was detected at $6 \mu \mathrm{g} / \mathrm{kg}$ in sample numbers TTR00892 and TTR00918. The total xylene detected above the method detection limit of $5 \mu \mathrm{g} / \mathrm{kg}$ was detected in sample number TTR00924. Both the 1,1,2,2-Tetrachloroethane and xylene detects were well below the preliminary action levels (EPA, 1996a). Carbon tetrachloride was detected in sample TTR00980 at the detection limit. All VOC detections were below preliminary action levels.

\section{A.3.2 Total Semivolatile Organic Compound Analytical Results}

An elevated level of pyrene was detected in sample number TTR00878 at a concentration of $880 \mu \mathrm{g} / \mathrm{kg}$. This level does not exceed the preliminary action level of 100,000 $\mu \mathrm{g} / \mathrm{kg}$ (EPA, 1996a). This soil sample was collected at the 1965-1975 Leachfield and shows a correlation to detectable concentrations of TPH as waste oil, which is discussed in the following section. Septic Tank 33-5 outfall sample number TTR00931 showed results above the minimum reporting limit (DOE/NV, 1997a) of $660 \mu \mathrm{g} / \mathrm{kg}$ for fluoranthene with a concentration of $710 \mu \mathrm{g} / \mathrm{kg}$. Fluoranthene has a preliminary action level of 270,000,000 $\mu \mathrm{g} / \mathrm{kg}(\mathrm{EPA}, 1996 \mathrm{a})$.

\section{A.3.3 Total Petroleum Hydrocarbon Results}

Total petroleum hydrocarbons were not detected in the gasoline and diesel ranges above the action level. However, there were detectable concentrations of waste oil exceeding the NDEP regulatory action level of $100 \mathrm{mg} / \mathrm{kg}$ for TPH as waste oil (Table A.3-4) . At the proximal end of the 1965-1975 Leachfield, all three upper interval trench samples (TTR00871, TTR00874, and TTR00878) had results exceeding $100 \mathrm{mg} / \mathrm{kg}$, indicating a distinct horizon of waste oil contamination at the leachfield base, with a maximum concentration of $2,400 \mathrm{mg} / \mathrm{kg}$. This concentration of waste oil did not affect the underlying native soil greater than $3 \mathrm{~m}$ (10 ft) below ground surface or migrate laterally, as all lower interval trench and borehole samples, including samples surrounding the leachfield boundary, did not contain elevated levels of TPH as waste oil. Abandoned Septic Tank 33-4 has contaminated 
Table A.3-4

\section{Summary of Total Petroleum Hydrocarbon Results Detected} Above Minimum Reporting Limit for Waste Oil

\begin{tabular}{|c|c|c|c|}
\hline \multirow{2}{*}{$\begin{array}{c}\text { Sample Location/ } \\
\text { Borehole }\end{array}$} & \multirow[b]{2}{*}{ Sample Number } & \multirow{2}{*}{$\begin{array}{c}\text { Sample Depth } \\
\text { (ft bgs) }\end{array}$} & \multirow{2}{*}{$\begin{array}{c}\text { Parameter- Waste Oil } \\
\text { Units } \\
(\mathrm{mg} / \mathrm{kg})\end{array}$} \\
\hline & & & \\
\hline LF1-T1 & TTR00867 & 4.6 & 120 \\
\hline \multirow{4}{*}{$\begin{array}{l}\text { LF2-T1 \& LF2-T1- } \\
\text { Cutback }\end{array}$} & TTR00871 & 5.5 & 2400 \\
\hline & TTR00872 & 7.7 & 62 \\
\hline & TTR00874 & 6.0 & 1600 \\
\hline & TTR00878 & 10.0 & 680 \\
\hline LF3-T1 & TTR00885 & 5.5 & 370 \\
\hline \multirow{4}{*}{ LF4-T1 } & TTR00887 & 6.0 & 230 \\
\hline & TTR00896 & 12.0 & 39 \\
\hline & TTR00897 & 12.0 & 54 \\
\hline & TTR00898 & 7.0 & 1500 \\
\hline LF5-T5 & TTR00925 & 9.5 & $31(\mathrm{~J})$ \\
\hline Tank 33-4 & TTR00929 & 5.0 & 2900 \\
\hline Tank 33-4-SB & TTR00945 & 10.0 & 1300 \\
\hline LF4-DBOX-SB & TTR00966 & 7.5 & 560 \\
\hline LF4-T1-20.0SEEP-SB & TTR00975 & 10.0 & 140 \\
\hline \multirow{3}{*}{$\begin{array}{l}\text { LF4-T1-40.0SEEP } \\
\text { (U/G)-SB }\end{array}$} & TTR00990 & 12.5 & 180 \\
\hline & TTR00991 & 17.5 & 330 \\
\hline & TTR00993 & 27.5 & 1100 \\
\hline Tank 33-5 & TTR0931, TR0933 & 7.4 & 610 \\
\hline Tank 33-6 & TTR01048 & 8.5 & 42 \\
\hline
\end{tabular}

$\mathrm{J}=$ Estimated value

soil underneath the outfall end (TTR00929) and the results for borehole Tank 33-4-SB indicate elevated concentrations at the 2.3- to 3-m (7.5- to 10.0-ft) interval (TTR00945) with underlying intervals below $100 \mathrm{mg} / \mathrm{kg}$. The majority of the upper interval trench samples at the Post-1975 Leachfield (TTR00867, TTR00885, TTR00887, and TTR00898) also showed elevated levels for TPH as waste oil. Sample number TTR00966 (borehole LF4-DBOX-SB) collected at a depth of 2 to $2.3 \mathrm{~m}$ (6.5 to $7.5 \mathrm{ft})$ bgs indicates shallow waste oil contamination below the former distribution point. Underlying interval results were nondetectable. Small concentrations of waste oil contamination were detected in the vicinity of the central seepage pit and at the end of the northern 
distribution pipe for the Post-1975 system. Core samples from borehole LF4-T1-20.0SEEP-SB, placed upgradient from the actual center-pipe seepage pit, resulted in a single elevated sample (TTR00975) at the depth interval of 2.3 to $3 \mathrm{~m}$ (7.5 to $10 \mathrm{ft}) \mathrm{bgs}$. Waste oil was also detected at the terminating end of the northern distribution pipe. An elevated concentration was detected in sample number TTR01031 collected from borehole LF4-T1-40.0SEEPCENTER(2nd)-SB at 6.0 to $6.8 \mathrm{~m}$ (20.0 to $22.5 \mathrm{ft}$ ). Analytical results from borehole LF4-T1-40.0SEEP(U/G)-SB detected elevated waste oil concentrations in sample numbers TTR00990, TTR00991, and TTR00993. Respective depth intervals are 3.0 to $3.8 \mathrm{~m}$ (10.0 to $12.5 \mathrm{ft}) \mathrm{bgs}, 4.5$ to $5.3 \mathrm{~m}$ (15.0 to $17.5 \mathrm{ft}) \mathrm{bgs}$, and 7.5 to $8.3 \mathrm{~m}(25.0$ to $27.5 \mathrm{ft})$ bgs.

\section{A.3.4 Total RCRA Metals Results}

The total RCRA metals detected above the minimum reporting limits (DOE/NV, 1997a) are presented in Table A.3-5. The total RCRA metals results were all below the preliminary action levels for the metal constituents except for arsenic (EPA, 1996a). Arsenic was detected above the PRG $(2.4 \mathrm{mg} / \mathrm{kg})$ in all samples. The majority of the arsenic results was consistent with background levels $(24.1 \mathrm{mg} / \mathrm{kg})$ established in the TTR Area 3 CAU 424 corrective action investigation (DOE/NV, 1998). Septic Waste Systems 2 \& 6 investigations indicate that a few isolated results exceeded $20 \mathrm{mg} / \mathrm{kg}$, with a maximum of $25.2 \mathrm{mg} / \mathrm{kg}$ in sample number TTR00946. Two spatial groups of samples represent higher background concentrations apparently resulting from fill material placed in specific geographic locations. Specifically, these groups are located in the vicinity of the Pre-1965 Leachfield and at the north end of Building 03-70. These are upper and lower trench samples with concentrations ranging from approximately 10 to $20 \mathrm{mg} / \mathrm{kg}$. Based on this information, the concentrations of arsenic are believed to be representative of ambient conditions.

\section{A.3.5 PCB Analytical Results}

There were no PCBs detected above the minimum reporting limits specified in the CAIP (DOE/NV, 1997a).

\section{A.3.6 Gamma Spectroscopy Results}

With the exception of potassium-40, all radiological results were within the preliminary action levels established through background locations and background levels for the State of Nevada (McArthur 
Table A.3-5

Soil Sample Results for Total RCRA Metal Constituents Detected Above Minimum Reporting Limits, Area 3 SWS 2 \& 6, TTR

(Page 1 of 5 )

\begin{tabular}{|c|c|c|c|c|c|c|}
\hline \multirow{3}{*}{$\begin{array}{c}\text { Sample } \\
\text { Location/ } \\
\text { Borehole }\end{array}$} & \multirow{3}{*}{$\begin{array}{c}\text { Sample } \\
\text { Number } \\
\begin{array}{c}\text { Industrial PRGa } \\
\text { (mg/kg) }\end{array}\end{array}$} & \multirow{3}{*}{$\begin{array}{l}\text { Sample } \\
\text { Depth } \\
\text { (ft bgs) }\end{array}$} & \multicolumn{4}{|c|}{ Parameters in milligrams per kilogram $(\mathrm{mg} / \mathrm{kg})$} \\
\hline & & & Arsenic & Barium & Chromium & Lead \\
\hline & & & 2.4 & 100000 & 450 & 1000 \\
\hline \multirow{2}{*}{ LF1-T1 } & TTR00867 & 4.6 & $8.3(\mathrm{~J})$ & $104(\mathrm{~J})$ & 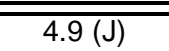 & $13.8(\mathrm{~J})$ \\
\hline & TTR00869 & 9.8 & $5.3(\mathrm{~J})$ & $124(\mathrm{~J})$ & $3.1(\mathrm{~J})$ & $6.2(\mathrm{~J})$ \\
\hline \multirow{5}{*}{$\begin{array}{c}\text { LF2-T1 \& LF2-T1- } \\
\text { Cutback }\end{array}$} & TTR00871 & 5.5 & 13.6 & 124 & 5.3 & 27.6 \\
\hline & TTR00872 & 7.7 & 6.8 & 131 & 3.4 & 7.0 \\
\hline & TTR00874 & 6.0 & $7.0(\mathrm{~J})$ & $150(\mathrm{~J})$ & $4.2(\mathrm{~J})$ & $21.4(\mathrm{~J})$ \\
\hline & TTR00876 & 8.0 & $6.6(\mathrm{~J})$ & $112(\mathrm{~J})$ & $3.4(\mathrm{~J})$ & $7.0(\mathrm{~J})$ \\
\hline & TTR00878 & 10.0 & $7.9(\mathrm{~J})$ & $120(\mathrm{~J})$ & $3.9(J)$ & $14.2(\mathrm{~J})$ \\
\hline \multirow{5}{*}{ LF2-T2 } & TTR00879 & 4.0 & 11.0 & 150 & 2.5 & 5.7 \\
\hline & TTR00880 & 7.5 & $11.8(\mathrm{~J})$ & $168(\mathrm{~J})$ & $2.7(\mathrm{~J})$ & $8.5(\mathrm{~J})$ \\
\hline & TTR00881 & 7.5 & $10.8(\mathrm{~J})$ & $155(\mathrm{~J})$ & $2.0(\mathrm{~J})$ & $5.5(\mathrm{~J})$ \\
\hline & TTR00882 & 4.0 & $12.3(\mathrm{~J})$ & $129(\mathrm{~J})$ & $2.4(\mathrm{~J})$ & $5.5(\mathrm{~J})$ \\
\hline & TTR00883 & 7.5 & 7.8 & 193 & 2.4 & 5.6 \\
\hline LF3-T1 & TTR00885 & 5.5 & 3.7 & 70.2 & 3.4 & 8.1 \\
\hline \multirow{2}{*}{ LF4-T1 } & TTR00887 & 6.0 & 6.6 & 191 & 4.1 & 6.9 \\
\hline & TTR00888 & 9.0 & 7.1 & 164 & 3.6 & 6.1 \\
\hline \multirow{4}{*}{ LF5-T1 } & TTR00890 & 6.0 & 16.8 & 81.9 & 2.9 & 5.5 \\
\hline & TTR00891 & 9.0 & 12.0 & 84.6 & 3.4 & 5.5 \\
\hline & TTR00892 & 6.0 & 18.4 & 138 & 2.9 & 5.0 \\
\hline & TTR00893 & 9.0 & 13.7 & 146 & 3.5 & 5.7 \\
\hline \multirow{5}{*}{ LF4-T1 } & TTR00895 & 9.0 & 8.3 & 180 & 3.5 & 6.4 \\
\hline & TTR00896 & 12.0 & 6.5 & 157 & 3.8 & 8.4 \\
\hline & TTR00897 & 12.0 & 8.8 & 164 & 3.3 & 7.6 \\
\hline & TTR00898 & 7.0 & 5.8 & 114 & 5.7 & 17.1 \\
\hline & TTR00899 & 9.5 & 7.5 & 113 & 3.6 & 5.7 \\
\hline LF5-T2 & TTR00900 & 6.0 & 11.5 & 135 & 4.2 & 7.7 \\
\hline LF3-T1 & TTR00903 & 10.0 & 4.7 & 119 & 2.3 & 4.8 \\
\hline LF5-T2 & TTR00904 & 10.0 & 7.7 & 177 & 3.6 & 6.5 \\
\hline \multirow{2}{*}{ LF5-T2- Cutback } & TTR00906 & 7.0 & 9.3 & $177(\mathrm{~J})$ & 2.1 & $6.6(\mathrm{~J})$ \\
\hline & TTR00907 & 10.0 & 9.8 & $89.3(\mathrm{~J})$ & 2.4 & $5.5(\mathrm{~J})$ \\
\hline \multirow{2}{*}{ LF5-DBOX } & TTR00908 & 8.0 & 8.2 & $90.2(\mathrm{~J})$ & 2.7 & $4.1(\mathrm{~J})$ \\
\hline & TTR00910 & 10.0 & 7.7 & $135(\mathrm{~J})$ & 3.5 & $6.3(\mathrm{~J})$ \\
\hline
\end{tabular}


Table A.3-5

Soil Sample Results for Total RCRA Metal Constituents Detected Above Minimum Reporting Limits, Area 3 SWS 2 \& 6, TTR

(Page 2 of 5 )

\begin{tabular}{|c|c|c|c|c|c|c|}
\hline \multirow{3}{*}{$\begin{array}{c}\text { Sample } \\
\text { Location/ } \\
\text { Borehole }\end{array}$} & \multirow{3}{*}{$\begin{array}{c}\text { Sample } \\
\text { Number } \\
\begin{array}{c}\text { Industrial PRGa } \\
(\mathrm{mg} / \mathrm{kg})\end{array}\end{array}$} & \multirow{3}{*}{$\begin{array}{l}\text { Sample } \\
\text { Depth } \\
\text { (ft bgs) }\end{array}$} & \multicolumn{4}{|c|}{ Parameters in milligrams per kilogram $(\mathrm{mg} / \mathrm{kg})$} \\
\hline & & & Arsenic & Barium & Chromium & Lead \\
\hline & & & 2.4 & 100000 & 450 & 1000 \\
\hline \multirow{4}{*}{ LF5-T3 } & TTR00911 & 7.0 & 12.6 & $174(\mathrm{~J})$ & 3.1 & $4.2(\mathrm{~J})$ \\
\hline & TTR00912 & 10.0 & 23.1 & $87.9(\mathrm{~J})$ & 3.6 & $5.0(\mathrm{~J})$ \\
\hline & TTR00913 & 7.0 & 21.6 & $109(\mathrm{~J})$ & 2.7 & $4.7(\mathrm{~J})$ \\
\hline & TTR00914 & 10.0 & 10.0 & $130(\mathrm{~J})$ & 2.1 & $4.5(\mathrm{~J})$ \\
\hline \multirow{4}{*}{ LF5-T4 } & TTR00915 & 8.0 & $6.3(\mathrm{~J})$ & $118(\mathrm{~J})$ & $1.6(\mathrm{~J})$ & $6.7(\mathrm{~J})$ \\
\hline & TTR00916 & 10.0 & 8.1 & $115(\mathrm{~J})$ & 2.5 & $4.8(\mathrm{~J})$ \\
\hline & TTR00918 & 7.0 & 10.8 & $74.1(\mathrm{~J})$ & 2.2 & $5.9(\mathrm{~J})$ \\
\hline & TTR00919 & 10.0 & 10.6 & $213(\mathrm{~J})$ & 2.9 & $5.4(J)$ \\
\hline \multirow{5}{*}{ LF5-T5 } & TTR00921 & 7.0 & 13.7 & $559(\mathrm{~J})$ & 3.0 & $22.3(\mathrm{~J})$ \\
\hline & TTR00922 & 10.0 & 13.4 & $137(J)$ & 3.2 & $5.7(J)$ \\
\hline & TTR00923 & 10.0 & 12.6 & $174(J)$ & 3.8 & $6.1(\mathrm{~J})$ \\
\hline & TTR00924 & 7.0 & 15.2 & $119(\mathrm{~J})$ & 4.0 & $7.0(\mathrm{~J})$ \\
\hline & TTR00925 & 9.5 & 16.1 & $143(\mathrm{~J})$ & 3.8 & $7.3(\mathrm{~J})$ \\
\hline Tank 33-4 & TTR00929 & 5.0 & 9.6 & $150(\mathrm{~J})$ & 5.7 & $29.9(\mathrm{~J})$ \\
\hline Tank 33-5 & TTR00931 & 7.4 & 14.7 & 136 & 6.0 & 11.0 \\
\hline \multirow{2}{*}{ Tank 33-4-SB } & TTR00945 & 10.0 & 9.8 & 129 & 4.4 & $28.5(\mathrm{~J})$ \\
\hline & TTR00946 & 14.5 & 25.2 & 133 & 3.7 & 6.1 \\
\hline \multirow{4}{*}{$\begin{array}{c}\text { LF2-SE } \\
\text { CORNER-SB }\end{array}$} & TTR00948 & 10.0 & 8.5 & 132 & 4.5 & 8.0 \\
\hline & TTR00949 & 15.0 & 5.2 & 148 & 1.2 & 4.4 \\
\hline & TTR00950 & 15.0 & 5.1 & 82.4 & 1.8 & 3.3 \\
\hline & TTR00951 & 20.0 & 6.4 & 148 & 6.1 & 6.0 \\
\hline \multirow{3}{*}{ LF2-T1-3.0- SO-SB } & TTR00955 & 10.0 & 6.5 & 99.3 & 3.0 & 4.9 \\
\hline & TTR00956 & 15.0 & 9.2 & 173 & 3.2 & 6.2 \\
\hline & TTR00957 & 20.0 & 7.6 & 200 & 3.1 & 8.4 \\
\hline \multirow{3}{*}{ LF2-WEST- SB } & TTR00959 & 7.5 & 7.3 & 162 & 4.8 & 6.6 \\
\hline & TTR00960 & 12.5 & 4.5 & 69.5 & 2.2 & 3.2 \\
\hline & TTR00961 & 17.5 & 7.0 & 134 & 3.9 & 6.5 \\
\hline \multirow{3}{*}{$\begin{array}{l}\text { LF2-SW } \\
\text { CORNER-SB }\end{array}$} & TTR00962 & 7.5 & 5.3 & 105 & 3.2 & 5.0 \\
\hline & TTR00963 & 12.5 & 5.4 & 95.2 & 2.0 & 3.3 \\
\hline & TTR00964 & 17.5 & 5.9 & 118 & 3.8 & 6.0 \\
\hline
\end{tabular}


Table A.3-5

Soil Sample Results for Total RCRA Metal Constituents Detected Above Minimum Reporting Limits, Area 3 SWS 2 \& 6, TTR

(Page 3 of 5)

\begin{tabular}{|c|c|c|c|c|c|c|}
\hline \multirow{3}{*}{$\begin{array}{c}\text { Sample } \\
\text { Location/ } \\
\text { Borehole }\end{array}$} & \multirow{3}{*}{$\begin{array}{c}\text { Sample } \\
\text { Number } \\
\begin{array}{c}\text { Industrial PRGa } \\
\text { (mg/kg) }\end{array}\end{array}$} & \multirow{3}{*}{$\begin{array}{l}\text { Sample } \\
\text { Depth } \\
\text { (ft bgs) }\end{array}$} & \multicolumn{4}{|c|}{ Parameters in milligrams per kilogram $(\mathrm{mg} / \mathrm{kg})$} \\
\hline & & & Arsenic & Barium & Chromium & Lead \\
\hline & & & 2.4 & 100000 & 450 & 1000 \\
\hline \multirow{3}{*}{ LF4-DBOX-SB } & TTR00966 & 7.5 & 9.1 & 7142 & 6.0 & 21.2 \\
\hline & TTR00968 & 12.5 & 5.9 & 140 & 2.4 & 6.4 \\
\hline & TTR00969 & 17.5 & 7.7 & 148 & 3.8 & 6.8 \\
\hline \multirow{4}{*}{$\begin{array}{l}\text { LF4-T1-1.0 } \\
\text { SEEP-SB }\end{array}$} & TTR00970 & 32.5 & 5.1 & 103 & 3.0 & 5.0 \\
\hline & TTR00971 & 37.5 & 5.9 & 117 & 3.1 & 7.2 \\
\hline & TTR00972 & 42.5 & 13.3 & 118 & 5.6 & 5.2 \\
\hline & TTR00974 & 42.5 & 6.0 & 90.1 & 3.5 & 5.0 \\
\hline \multirow{3}{*}{$\begin{array}{l}\text { LF4-T1-20.0 } \\
\text { SEEP-SB }\end{array}$} & TTR00975 & 10.0 & 7.8 & 105 & 2.4 & 6.0 \\
\hline & TTR00979 & 22.5 & 6.5 & 145 & 3.8 & 5.4 \\
\hline & TTR00980 & 27.5 & 4.8 & 125 & 2.9 & 4.1 \\
\hline \multirow{7}{*}{$\begin{array}{l}\text { LF4-T1-20.0 } \\
\text { SEEP(D/G)- SB }\end{array}$} & TTR00982 & 7.5 & 21.9 & 174 & 3.5 & 8.1 \\
\hline & TTR00983 & 12.5 & 5.8 & 133 & 3.1 & 5.4 \\
\hline & TTR00984 & 17.5 & 11.5 & 120 & 3.6 & 6.2 \\
\hline & TTR00985 & 22.5 & 7.8 & 110 & 2.4 & 5.5 \\
\hline & TTR00986 & 27.5 & 5.0 & 105 & 2.4 & 4.9 \\
\hline & TTR00987 & 32.5 & 7.1 & 168 & 27.3 & 6.1 \\
\hline & TTR00988 & 37.5 & 4.5 & 129 & 4.7 & 6.0 \\
\hline \multirow{6}{*}{$\begin{array}{c}\text { LF4-T1-40.0 } \\
\text { SEEP(U/G)- SB }\end{array}$} & TTR00990 & 12.5 & 4.2 & 78.2 & 3.6 & 7.1 \\
\hline & TTR00991 & 17.5 & 3.6 & 58.8 & 3.2 & 7.7 \\
\hline & TTR00992 & 22.5 & 3.1 & 43.9 & 1.9 & 6.6 \\
\hline & TTR00993 & 27.5 & 6.8 & 127 & 3.8 & 5.9 \\
\hline & TTR00994 & 35.0 & 4.7 & 99.5 & 3.3 & 5.9 \\
\hline & TTR00995 & 42.5 & 4.9 & 95.5 & 3.2 & 5.0 \\
\hline \multirow{2}{*}{$\begin{array}{l}\text { 40.0 SEEP- } 29.0 \\
(\mathrm{U} / \mathrm{G})-\mathrm{SB}\end{array}$} & TTR00997 & 10.0 & 7.1 & 125 & 5.6 & 6.3 \\
\hline & TTR00998 & 15.0 & 7.6 & 146 & 2.8 & 9.3 \\
\hline \multirow{2}{*}{$\begin{array}{c}20.0 \text { SEEP- } 29.0 \\
(U / G)-S B\end{array}$} & TTR00999 & 10.0 & 5.6 & 121 & 2.8 & 4.9 \\
\hline & TTR01000 & 15.0 & 24.3 & 142 & 3.0 & 5.4 \\
\hline \multirow{3}{*}{ DBOX-RS-SB } & TTR01002 & 10.0 & 6.6 & 124 & 3.1 & 6.4 \\
\hline & TTR01004 & 19.0 & 8.4 & 142 & 2.7 & 9.5 \\
\hline & TTR01007 & 25.0 & 5.8 & 103 & 2.8 & 6.3 \\
\hline
\end{tabular}


Table A.3-5

Soil Sample Results for Total RCRA Metal Constituents Detected Above Minimum Reporting Limits, Area 3 SWS 2 \& 6, TTR

(Page 4 of 5)

\begin{tabular}{|c|c|c|c|c|c|c|}
\hline \multirow{3}{*}{$\begin{array}{l}\text { Sample } \\
\text { Location/ } \\
\text { Borehole }\end{array}$} & \multirow{3}{*}{$\begin{array}{c}\text { Sample } \\
\text { Number } \\
\begin{array}{c}\text { Industrial PRGa } \\
\text { (mg/kg) }\end{array}\end{array}$} & \multirow{3}{*}{$\begin{array}{l}\text { Sample } \\
\text { Depth } \\
\text { (ft bgs) }\end{array}$} & \multicolumn{4}{|c|}{ Parameters in milligrams per kilogram $(\mathrm{mg} / \mathrm{kg})$} \\
\hline & & & Arsenic & Barium & Chromium & Lead \\
\hline & & & 2.4 & 100000 & 450 & 1000 \\
\hline \multirow{3}{*}{ LF2-T1-17.0-RS-SB } & TTR01008 & 10.0 & 8.2 & 135 & 5.3 & $\overline{8.6}$ \\
\hline & TTR01009 & 17.5 & 6.5 & 108 & 2.5 & 6.9 \\
\hline & TTR01010 & 22.5 & 7.3 & 126 & 2.6 & 5.5 \\
\hline \multirow{4}{*}{$\begin{array}{l}\text { LF4-T1-20.0 SEEP } \\
\text { CENTER-SB }\end{array}$} & TTR01012 & 22.5 & 6.8 & $150(\mathrm{~J})$ & 2.6 & $6.9(\mathrm{~J})$ \\
\hline & TTR01013 & 26.0 & 6.2 & $132(\mathrm{~J})$ & 3.0 & $4.4(\mathrm{~J})$ \\
\hline & TTR01014 & 32.5 & 6.1 & $76.6(\mathrm{~J})$ & 4.8 & $5.7(\mathrm{~J})$ \\
\hline & TTR01015 & 37.5 & 6.8 & $91.3(\mathrm{~J})$ & 4.1 & $5.9(\mathrm{~J})$ \\
\hline \multirow{8}{*}{$\begin{array}{l}\text { LF4-T1-40.0 } \\
\text { (D/G)-SB }\end{array}$} & TTR01016 & 10.0 & 11.3 & $139(\mathrm{~J})$ & 2.0 & $5.4(J)$ \\
\hline & TTR01017 & 15.0 & 9.2 & $108(\mathrm{~J})$ & 1.4 & $5.6(J)$ \\
\hline & TTR01018 & 20.0 & 8.2 & $143(\mathrm{~J})$ & 1.9 & $8.9(\mathrm{~J})$ \\
\hline & TTR01019 & 20.0 & 8.4 & $176(\mathrm{~J})$ & 2.2 & $10.3(\mathrm{~J})$ \\
\hline & TTR01020 & 25.0 & 5.5 & $95.2(\mathrm{~J})$ & 2.2 & $3.8(\mathrm{~J})$ \\
\hline & TTR01021 & 30.0 & 5.5 & $125(\mathrm{~J})$ & 3.5 & $4.5(\mathrm{~J})$ \\
\hline & TTR01022 & 35.0 & 5.5 & $101(\mathrm{~J})$ & 10.0 & $4.5(\mathrm{~J})$ \\
\hline & TTR01024 & 40.0 & 7.4 & $108(\mathrm{~J})$ & 6.1 & $4.5(\mathrm{~J})$ \\
\hline \multirow{7}{*}{$\begin{array}{l}\text { LF4-T1-40.0 SEEP } \\
\text { CENTER (2nd)-SB }\end{array}$} & TTR01029 & 17.5 & 7.4 & $109(\mathrm{~J})$ & 2.2 & $5.2(\mathrm{~J})$ \\
\hline & TTR01030 & 22.5 & 9.8 & $156(\mathrm{~J})$ & 2.3 & $5.7(\mathrm{~J})$ \\
\hline & TTR01031 & 27.5 & 7.3 & $166(\mathrm{~J})$ & 2.8 & $6.2(\mathrm{~J})$ \\
\hline & TTR01032 & 34.0 & 7.4 & $117(\mathrm{~J})$ & 7.7 & $6.0(\mathrm{~J})$ \\
\hline & TTR01033 & 39.0 & 7.8 & 106 & 3.5 & 5.1 \\
\hline & TTR01035 & 44.0 & 5.3 & 100 & 4.6 & 3.7 \\
\hline & TTR01036 & 44.0 & 7.9 & 109 & 6.5 & 3.8 \\
\hline
\end{tabular}




\section{Table A.3-5}

\section{Soil Sample Results for Total RCRA Metal Constituents Detected Above Minimum Reporting Limits, Area 3 SWS 2 \& 6, TTR}

(Page 5 of 5 )

\begin{tabular}{|c|c|c|c|c|c|c|}
\hline \multirow{3}{*}{$\begin{array}{l}\text { Sample } \\
\text { Location/ } \\
\text { Borehole }\end{array}$} & \multirow{3}{*}{$\begin{array}{c}\text { Sample } \\
\text { Number } \\
\begin{array}{c}\text { Industrial PRGa } \\
(\mathrm{mg} / \mathrm{kg})\end{array}\end{array}$} & \multirow{3}{*}{$\begin{array}{l}\text { Sample } \\
\text { Depth } \\
\text { (ft bgs) }\end{array}$} & \multicolumn{4}{|c|}{ Parameters in milligrams per kilogram $(\mathrm{mg} / \mathrm{kg})$} \\
\hline & & & Arsenic & Barium & Chromium & Lead \\
\hline & & & 2.4 & 100000 & 450 & 1000 \\
\hline \multirow{8}{*}{$\begin{array}{c}\text { LF4-T1-1.0 } \\
\text { SEEP(D/G)-SB }\end{array}$} & TTR01038 & 7.5 & 11.7 & 113 & 3.5 & 6.6 \\
\hline & TTR01039 & 12.5 & 7.1 & 164 & 3.0 & 6.6 \\
\hline & TTR01040 & 17.5 & 9.2 & 150 & 3.5 & 6.2 \\
\hline & TTR01041 & 22.5 & 6.5 & 121 & 2.2 & 5.0 \\
\hline & TTR01042 & 27.5 & 7.4 & 139 & 4.4 & 8.6 \\
\hline & TTR01043 & 32.5 & 6.9 & 172 & 4.8 & 6.3 \\
\hline & TTR01044 & 37.5 & 4.4 & 117 & 4.8 & 3.8 \\
\hline & TTR01045 & 42.5 & 6.5 & 83.5 & 5.1 & 5.1 \\
\hline Tank 33-6 & TTR01048 & 8.5 & 7.7 & 116 & 3.4 & 6.0 \\
\hline
\end{tabular}

-- = Not detected above minimum reporting limit as specified in the CAIP (DOE/NV, 1997a)

aU.S. Environmental Protection Agency, Region 9 Preliminary Remediation Goals, 1996 (EPA, 1996a)

$\mathrm{J}=$ Estimated value

and Miller, 1989). Potassium-40 was detected at levels above background levels (10.5-30.7 pCi/g) (McArthur and Miller, 1989) in three samples: sample number TTR01012 from boring LF4-TI-20.0SEEPCENTER-SB at $6 \mathrm{~m}$ to $6.9 \mathrm{~m}$ (20 to $22.5 \mathrm{ft}$ ), sample number TTR01031 from boring LF4-TI-40.0SEEPCENTER(2nd)-SB at $7.6 \mathrm{~m}$ to $8.4 \mathrm{~m}$ (25 ft to $27.5 \mathrm{ft}$ ), and sample number TTR01043 from boring LF4-TI-1.0SEEP(D/G)-SB at $9 \mathrm{~m}$ to $9.9 \mathrm{~m} \mathrm{(30} \mathrm{ft} \mathrm{to} 32.5 \mathrm{ft})$. These samples were obtained from the terminal ends of the leachfield pipes at the 1965-1975 Leachfield. No process knowledge was identified during the development of the CAIP that would indicate the potential for radiological contamination. The presence of potassium-40 in nature is due to the fact that approximately 0.012 percent of all potassium atoms are radioactive potassium-40. It is not created during nuclear fission. The potassium-40 concentrations measured initially in these samples exceeded that found in pure potassium compounds such as potassium phosphate and potassium permanganate. A potassium-40 concentration of $861 \mathrm{pCi} / \mathrm{g}$ exceeds the theoretical potassium-40 concentration in pure potassium metal. Because of the unexpected nature of these radiological detections, the samples were reanalyzed at the laboratory to verify the results. 
The second analysis demonstrated that the potassium-40 concentrations in these samples varied from 11 to $23.5 \mathrm{pCi} / \mathrm{g}$ and are not different than the concentrations found in soil samples taken from background locations; therefore, the results were within PALs discussed above and there is no potassium-40 contamination at this site.

\section{A.3.7 Septic Tank 33-5 Samples}

Most constituents were not detected in samples TTR-335-1 and TTR-335-2. Those constituents that were detected were at concentrations below Industrial PRGs as presented in Table A.3-6. Only enough fluid could be collected from the tank to request analysis for TPH and VOCs on sample TTR-335-1. Sample number TTR-335-2 was taken from the sludge within the tank and analyzed for TPH, VOCs, SVOCs, Pesticides, and TCLP Metals. Note that during this investigation, only sample TTR-335-2 was analyzed for Pesticides. Process knowledge did not indicate that pesticides should be considered COPCs. Beta-BHC, 4,4'-DDE, and Endosulfan Sulfate were detected in sample TTR-335-2 at levels below Industrial PRGs for soils. No evidence was encountered during the investigation to indicate that Septic Tank 33-5 had been breached.

\section{A.3.8 Geotechnical Results}

A geotechnical sample was collected from below each leachfield distribution box or point: sample number TTR00966 from the Post-1975 Leachfield, TTR00935 from the 1965-1975 Leachfield, and TTR00909 from the Pre-1965 Leachfield. The data were collected to provide input for closure options. The results of the geotechnical observations suggest that the subsurface soil ranges from a well-graded sand with silt and gravel to a clayey-sand with gravel. This is typical of alluvial materials found at the Area 3 Compound. The results of the laboratory analysis of the geotechnical samples are presented in Attachment 1. 
Table A.3-6

Sample Results for Constituents Detected in Septic Tank 33-5, Area 3 SWS $2 \& 6$, TTR

\begin{tabular}{|c|c|c|c|c|c|}
\hline $\begin{array}{l}\text { Sample } \\
\text { Number }\end{array}$ & $\begin{array}{c}\text { Analytical } \\
\text { Method }\end{array}$ & Matrix & PRGaParameter & Industrial PRG ${ }^{a}$ & Results \\
\hline \multirow{2}{*}{ TTR-335-1 } & EPA $8015 \mathrm{M}$ & \multirow{2}{*}{ Aqueous } & Oil Range & NA & $7.1 \mathrm{mg} / \mathrm{L}$ \\
\hline & EPA 8260A & & Naphthalene & $240,000 \mu \mathrm{g} / \mathrm{kg}$ & $5 \mu \mathrm{g} / \mathrm{L}$ \\
\hline \multirow{9}{*}{ TTR-335-2 } & \multirow{6}{*}{ EPA 8260A } & \multirow{9}{*}{ Solid } & Naphthalene & $240,000 \mu \mathrm{g} / \mathrm{kg}$ & $550 \mu \mathrm{g} / \mathrm{kg}$ \\
\hline & & & 1,4-Dichlorobenzene & $8500 \mu \mathrm{g} / \mathrm{kg}$ & $1400 \mu \mathrm{g} / \mathrm{kg}$ \\
\hline & & & p-Isopropyltoluene & ND & $28 \mu \mathrm{g} / \mathrm{kg}$ \\
\hline & & & Carbon Disulfide & $24,000 \mu \mathrm{g} / \mathrm{kg}$ & $35 \mu \mathrm{g} / \mathrm{kg}$ \\
\hline & & & Toluene & $880,000 \mu \mathrm{g} / \mathrm{kg}$ & $1500 \mu \mathrm{g} / \mathrm{kg}$ \\
\hline & & & 1,2,4-Trimethylbenzene & ND & $45 \mu \mathrm{g} / \mathrm{kg}$ \\
\hline & \multirow{3}{*}{ EPA 8081} & & beta-BHC & $1100 \mu \mathrm{g} / \mathrm{kg}$ & $73 \mu \mathrm{g} / \mathrm{kg}$ \\
\hline & & & 4,4'-DDE & $5600 \mu \mathrm{g} / \mathrm{kg}$ & $30 \mu \mathrm{g} / \mathrm{kg}$ \\
\hline & & & Endosulfan Sulfate & $4,100,000 \mu \mathrm{g} / \mathrm{kg}$ & $270 \mu \mathrm{g} / \mathrm{kg}$ \\
\hline
\end{tabular}

aU.S. Environmental Protection Agency, Region 9 Preliminary Remediation Goals, 1996 (EPA, 1996a)

$\mathrm{NA}=$ Not applicable

$\mathrm{ND}=$ Not Determined 


\section{A.4.0 Quality Assurance}

The results of QA/QC activities for the Area 3 SWS $2 \& 6$ Corrective Action Investigation sampling event are summarized in the following text. The QA/QC procedures related to the geotechnical samples and analyses are contained in the Standard Specification for Transportation Materials and Methods of Sampling and Testing (ASSHTO, 1995) and are not discussed further in this text. Detailed information on the QA program for this sampling event is contained in the Industrial Sites Quality Assurance Project Plan, Revision 1 (DOE/NV, 1996b).

Quality control results are typically judged in terms of the five PARCC (precision, accuracy, representativeness, completeness, and comparability) parameters as described in the following sections.

\section{A.4.1 Precision}

Precision is a quantitative measure of the variability of a group of measurements from their average value. Precision is assessed by collecting and analyzing duplicate field samples and comparing the results with the original sample. Precision is also assessed by creating, analyzing, and comparing laboratory duplicates from one or more field samples. Precision is reported as relative percent difference (RPD) which is calculated as the difference between the measured concentrations of duplicate samples, divided by the average of the two concentrations, and multiplied by 100 .

\section{A.4.2 Accuracy}

Analytical accuracy is defined as the nearness of a measurement to the true or accepted reference value. It is the composite of the random and systematic components of the measurement system and measures bias in the measurement system. The random component of accuracy is measured and documented through the analyses of spiked samples. Sampling accuracy is assessed by evaluating the results of spiked samples and laboratory control samples. Accuracy measurements are calculated as percent recovery by dividing the measured sample concentration by the true concentration and multiplying the quotient by 100 . 
Field accuracy is assessed by confirming that the documents of record track the sample from its origin, through transfer of custody, to disposal. The goal of field accuracy is for all samples to be collected from the correct locations at the correct time, placed in a correctly labeled container with the correct preservative, and sealed with custody tape to prevent tampering. All samples in this sampling event were properly collected and forwarded to the laboratory as described above.

\section{A.4.3 Representativeness}

Representativeness expresses the degree to which sample data accurately and precisely represent a characteristic of a population, parameter variations at a sampling point, or an environmental condition (EPA, 1987). Sample representativeness was achieved through the implementation of a sampling program designed to ensure proper sampling locations, number of samples, and the use of validated analytical methods. Representativeness was assessed through analysis of duplicate samples. Representativeness of the samples taken in this sampling event was assured by collecting the required samples shown in Section A.2.0 and by analyzing them by the approved analytical methods shown in Table A.3-2.

\section{A.4.4 Completeness}

Completeness is defined as a percentage of measurements made that are judged to be valid. A sampling and analytical requirement of 80 percent completeness was established for this project (DOE/NV, 1996a). The SWS 2 \& 6 sampling data exhibit a high degree of completeness. The specified sampling locations were utilized as planned. All samples were collected as specified in the CAIP (DOE/NV, 1997a), and all sample containers reached the laboratory intact and properly preserved (when applicable). For all samples, sample temperature was maintained during shipment to the laboratory, and sample chain of custody was maintained during sample storage and/or shipment.

\section{A.4.5 Comparability}

Comparability is a qualitative parameter expressing the confidence with which one dataset can be compared to another (EPA, 1987). To ensure comparability, the SWS 2 \& 6 field and sampling activities were performed and documented in accordance with approved procedures, and all samples were collected in accordance with the CAIP (DOE/NV, 1997a). Approved standardized methods and 
procedures were also used to analyze and report the data (e.g., Contract Laboratory Program [CLP] and/or CLP-like data packages). This approach ensures that the data from this project can be compared to other datasets. Based on the minimum comparability requirements specified in the Industrial Sites QAPP (DOE/NV, 1996b), all requirements were met.

Sample-handling documentation, laboratory nonconformance reports, and the precision and accuracy of quality-control sample results were evaluated for their effect on the results of the associated environmental soil samples. The environmental sample results were then qualified according to processes outlined in the following section. Documentation of the data qualifications resulting from these reviews is retained in project files as both hard copy and electronic media and will be supplied upon request.

\section{A.4.6 Tier I and Tier II Data Evaluations}

All laboratory data from samples collected at SWS $2 \& 6$ have been evaluated for data quality according to the procedures outlined in IT-Las Vegas Standard Quality Practices (IT, 1993). These procedures, performed in a tiered process, are based upon EPA data validation guidelines and presented in the following text, resulted in modifications to the laboratory-generated qualifiers or results. No data rejected during the data evaluation process were used to draw the conclusions presented in Section A.3.0. Only detections, whether estimated (i.e., J-qualified) or not, were used.

The changes resulting from the data evaluation process were documented in project files and were summarized in memoranda for each sample delivery group (SDG). These memoranda are maintained in IT project files and are available for inspection upon request.

\section{A.4.6.1 Tier I Evaluation}

Tier I evaluation for both chemical and radiological analysis examines (but is not limited to):

- Sample count/type consistent with chain of custody

- Analysis count/type consistent with chain of custody

- Correct sample matrix

- Significant problems stated in cover letter or case narrative

- Completeness of certificates of analysis (COAs)

- Completeness of CLP or CLP-like packages

- Completeness of signatures, dates and times on chain of custody 
- Condition-upon-receipt variance form included

- Requested analyses performed on all samples

- Date received/analyzed given for each sample

- Correct concentration units indicated

- Correct detection limits achieved

- Electronic data transfer (EDT) supplied

- Results reported for field and laboratory QC samples

- Whether or not the deliverable met the overall objectives of the project

\section{A.4.6.2 Tier II Evaluation}

Tier II evaluation for both chemical and radiological analysis examines (but is not limited to):

\section{Chemical:}

- Sample date, preparation date and analysis date for each sample

- Holding time criteria met

- QC batch association for each sample

- Cooler temperature upon receipt

- Sample pH for aqueous samples, as required

- Detection limits properly adjusted for dilution, as required

- Blank contamination evaluated and applied to sample results/qualifiers

- Matrix spike/matrix spike duplicate percent recoveries $(\% \mathrm{R})$ and RPDs evaluated and applied to laboratory results/qualifiers

- Field duplicate RPDs evaluated and applied to laboratory results/qualifiers

- Laboratory duplicate RPDs evaluated and applied to laboratory results/qualifiers

- Surrogate \%Rs evaluated and applied to laboratory results/qualifiers

- Laboratory control sample \%Rs evaluated and applied to laboratory results/qualifiers

\section{Radioanalytical:}

- Whether or not blank contamination evaluated and applied to sample results/qualifiers

- Whether or not Certificate of Analysis is consistent with data package documentation

- QC sample results (duplicates, laboratory control samples, matrix spikes and matrix spike duplicates) evaluated and applied to laboratory result qualifiers

- Whether or not sample results, error, and minimum detectable activity evaluated and applied to laboratory result qualifiers

- Whether or not the detector system was calibrated to National Institute for Standards and Technology (NIST) traceable sources

- Whether or not calibration sources preparation was documented, demonstrating proper preparation and appropriateness for sample matrix, emission energies, and concentrations

- Detector system response to daily, weekly, and monthly background and calibration checks for peak energy, peak centroid, peak full width half maximum, and peak efficiency

- Whether or not tracers were NIST-traceable, were appropriate for the analysis performed, and had recoveries that met QC requirements 
- Whether or not documentation of all QC sample preparation was complete and properly performed

- Whether or not spectra lines, emissions, particle energies, peak areas, and background peak areas support the identified radionuclide and its concentration

\section{A.4.6.3 Tier III}

Data quality considerations that are included in EPA data review functional guidelines as a Tier III review include the additional evaluations:

\section{Chemical:}

- Mass spectrometer tuning criteria

- Initial and continuing calibration verification

- Internal standard evaluation

- Organic compound quantitation

- Inductively coupled plasma (ICP) interference check sample evaluation

- Graphite furnace atomic absorption quality control

- ICP serial dilution effects

- Recalculation of all laboratory results from raw data

\section{Radioanalytical:}

- QC sample results (e.g., calibration source concentration, percent recovery, and RPD) verified

- Radionuclides and their concentration appropriate considering their decay schemes, half-lives, and process knowledge and history of the facility and site

- Each identified line in spectra verified against emission libraries and calibration results

- Independent identification of spectra lines, area under the peaks, and quantification of radionuclide concentration in a random number of sample results

Tier I and II data evaluations are summarized in a memorandum for each sample delivery group showing which results and qualifiers were changed and why these changes were made. A Tier III review of 5 percent of all the analytical data was performed by Lockheed Martin Technology Services in Las Vegas, Nevada. Changes to the data resulting from this review have been documented in IT project files and are included in the analytical summary tables in Section A.3.0.

\section{A.4.7 Quality Control Samples}

Thirty-three trip blanks, 7 field blanks, 7 equipment rinsate blanks, 6 matrix spike/matrix spike duplicates, and 6 field duplicates were collected and submitted for laboratory analysis as shown in Table A.3-1. The samples and duplicates were assigned individual sample numbers and sent to the 
laboratory "blind." Additional samples were selected by the laboratory to be analyzed as laboratory duplicates. The field blanks were taken by placing distilled water into appropriate sample bottles and preserving them according to the requirements specified in the Industrial Sites QAPP (DOE/NV, 1996b). The equipment rinsate blanks were obtained by collecting the final rinse solution (i.e., distilled water), which was poured over the decontaminated sampling equipment into the appropriate sample bottles and preserved as applicable. The trip blanks, which were received sealed and preserved from the laboratory, were placed in each cooler containing samples for VOC analysis. The results of the QC samples are discussed in the following sections.

\section{A.4.7.1 Field Quality Control Samples}

All blanks (i.e., field blanks, equipment rinsate blanks, and trip blanks) were analyzed for the parameters listed in Table A.3-2 (trip blanks were analyzed for VOCs only) and showed only contamination associated with a common laboratory contaminant (acetone as defined in the EPA Functional Guidelines) with the exception of ButylBenzylPhthalate in sample TTR00865, an equipment rinsate blank. This blank detection was used to qualify the results of the associated environmental sample according to EPA Functional Guidelines (EPA, 1994a; 1994b).

The EPA Functional Guidelines state that no qualification action is taken if a compound is found in an associated blank, but not in the sample or if a compound is found in the sample, but not in an associated blank. The action taken when a compound is detected in both the sample and the associated blank varies depending upon the analyte involved and is described in the "The $5 \mathrm{X} / 10 \mathrm{X}$ Rule."

For most VOCs, SVOCs, pesticides, and PCBs, an analyte detected in the sample that was also detected in an associated blank is qualified as undetected (U) if the sample concentration is less than five times (5X) the blank concentration. For the common laboratory contaminants (methylene chloride, acetone, 2-butanone [methylethyl ketone or MEK], toluene, and phthalate esters [especially bis(2-ethylhexyl)phthalate]), the factor is raised to ten times (10X) the blank concentration. The sample result is elevated to the quantitation limit if it is not already reported at that level.

For inorganics (metals), sample results greater than the instrument detection limit, but less than five times $(5 \mathrm{X})$ the amount found in an associated blank, are qualified as undetected $(\mathrm{U})$. There are no 
metallic common laboratory contaminants, so there is no "10X Rule" for metals, and the sample result is never altered.

During the sampling event, six field duplicate soil samples were sent as blind samples to the laboratory to be analyzed for the investigation parameters listed in Table A.3-2. For these samples, the duplicate results precision (i.e., relative percent differences between the environmental sample results and their corresponding field duplicate sample results) were compared to criteria set forth in EPA Functional Guidelines (EPA, 1994b; 1994c), and the associated environmental sample results were qualified accordingly.

The EPA Functional Guidelines give no required review criteria for field duplicate analyses comparability, but allow the data reviewer to exercise professional judgement. Both detections and nondetections have been qualified as estimated ( $\mathrm{J}$ and $\mathrm{UJ}$, respectively) if the relative percent difference between an environmental sample and its field duplicate fell outside established criteria.

Six field samples were selected for use as matrix spike/matrix spike duplicate samples. The percent recoveries of these samples (a measure of accuracy) and the relative percent differences in these sample results (a measure of precision) were compared to EPA Functional Guideline criteria (EPA, 1994b; 1994c). The results were used to qualify associated environmental sample results accordingly.

The EPA Functional Guidelines for review of organic data state that no data qualification action is taken on the basis of matrix spike/matrix spike duplicate results alone. The data reviewer exercises professional judgement in considering these results in conjunction with the results of laboratory control samples (LCSs) and other QC criteria in applying qualifications to the data. Generally, if recovery criteria are greater than the upper acceptance limit, then positive sample results for the affected compounds are qualified as estimated $(\mathrm{J})$, and nondetections are not qualified. If recovery criteria are less than the lower acceptance limit, then positive sample results for the affected compounds are qualified as estimated $(\mathrm{J})$ and nondetections are qualified as unusable $(\mathrm{R})$. The relative percent difference results of matrix spike/matrix spike duplicate samples that fall outside established criteria are applied to qualify detections and nondetections as estimated ( $\mathrm{J}$ and $\mathrm{UJ}$, respectively). 
The inorganic data review in EPA Functional Guidelines allows professional judgement to be applied in evaluating the results of both matrix spikes and laboratory duplicates. Generally, if spike recoveries are greater than the upper acceptance limit or less than the lower acceptance limit, positive results are qualified as estimated $(\mathrm{J})$ and nondetections are either unqualified or qualified as estimated (UJ), respectively. If spike recoveries are grossly low (less than 30 percent), positive results are unqualified, and nondetections are unusable (R). The relative percent difference between the environmental sample and its laboratory duplicate are compared to established criteria to qualify detections and nondetections as estimated ( $\mathrm{J}$ and $\mathrm{UJ}$, respectively).

Documentation of the data qualifications resulting from the application of these guidelines is retained in IT project files as both hard copy and electronic media and will be supplied upon request.

\section{A.4.7.2 Laboratory Quality Control Samples}

Analysis of method QC blanks and laboratory control samples was performed for each parameter analyzed by Quanterra Laboratory. In addition, laboratory duplicate analysis was performed on one metals analysis environmental sample per SDG. The results of these analyses were used to qualify associated environmental sample results according to EPA Functional Guidelines (EPA, 1994a; 1994b). The complete QC sample results are maintained in the IT project files.

\section{A.4.8 Field Deficiencies/Nonconformance}

During the SWS 2 \& 6 corrective action investigation activities, one QA surveillance was conducted by the contractor to verify that sampling activities were performed in accordance with applicable requirements. The results of the surveillance indicated no findings, deficiencies, or nonconformances with sampling activities as they met the requirements of the plans and procedures governing the activities at the site. Documentation of these results is retained in IT project files and will be supplied upon request. 


\section{A.5.0 Summary}

Analysis of the data generated from corrective action investigation activities conducted at the

SWS $2 \& 6$ indicates the following:

- With the exception of arsenic, the industrial preliminary remediation goal levels and the NDEP regulatory level of $100 \mathrm{mg} / \mathrm{kg}$ for TPH were not exceeded in any of the samples collected from the Area 3 SWS 2 \& 6 for Total VOC, Total SVOC, TPH (gasoline or diesel), Total RCRA Metals, and PCB analyses.

- TPH concentrations (as waste oil) were detected above the NDEP regulatory level of $100 \mathrm{mg} / \mathrm{kg}$. The waste oil is limited laterally to the confines of the two discovered leach systems and has exhibited a low degree of vertical migration, with very few elevated levels at depths greater than $3.0 \mathrm{~m}(10.0 \mathrm{ft}) \mathrm{bgs}$. There is a minor concentration of waste oil at the terminating ends of the northern and center distribution pipes of the Post-1975 Leachfield limited in vertical extent to $8.3 \mathrm{~m}(27.5 \mathrm{ft})$ bgs. Lateral extent of this waste oil is limited as defined by nondetectable concentrations downgradient at a similar borehole, separated horizontally by $2.1 \mathrm{~m}(7 \mathrm{ft})$.

- Arsenic concentrations were detected above the industrial PRG level; however, these concentrations were within the range of regional background concentrations detected for arsenic. Based on historical evidence (DOE/NV, 1997a) and the background concentrations, it is felt that arsenic is naturally occurring at these concentrations.

- With the exception of three Potassium-40 sample results, all initial results are below the preliminary action levels established and consistent with background levels established for the State of Nevada (McArthur and Miller, 1989), and radionuclide concentrations from the samples collected from SWS 2 \& 6 locations are not different than the concentrations found at background locations. The three samples with greater than background concentrations of Potassium-40 were reanalyzed and found to be within background concentrations. 


\section{A.6.0 References}

ASSHTO, see American Association of State Highway and Transportation Officials.

American Association of State Highway and Transportation Officials. 1995. Standard Specifications for Transportation Materials and Methods of Sampling and Testing. Washington, DC.

ASTM, see American Society for Testing Materials.

American Society for Testing Materials. 1996. Annual Book of American Society for Testing and Materials (ASTM) Standards, Section 4, "Construction," Volume 04.08, "Soil and Rock (1)," and Volume 04.09, "Soil and Rock (11)." Philadelphia, PA.

DOE, see U.S. Department of Energy.

DOE/NV, see U.S. Department of Energy, Nevada Operations Office.

EPA, see U.S. Environmental Protection Agency.

FFACO, see Federal Facility Agreement and Consent Order.

Federal Facility and Consent Order. 1996. Agreed to by the State of Nevada, the U.S. Department of Energy, and the U.S. Department of Defense.

IT, see IT Corporation.

IT Corporation. 1993 as amended. ITLV Program Procedures Manual. Las Vegas, NV.

IT Corporation. 1997. Site-Specific Health and Safety Plan for the Tonopah Test Range (TTR) Corrective Action Investigation CAU No. 427. Las Vegas, NV.

McArthur, R.D., and Miller, F.L., Jr. 1989. Off-site Radiation Exposure Review Project (ORERP), Phase II Soil Program, DOE/NV/10384-23. Las Vegas, NV: Desert Research Institute.

NAC, see Nevada Administrative Code.

Nevada Administrative Code. 1996. NAC 445A.227, "Contamination of soil: Order by director of corrective action; factors to be considered in determining whether corrective action is required." Carson City, NV.

USACE, see U.S. Army Corps of Engineers. 
U.S. Army Corps of Engineers. 1970. Laboratory Soils Testing, Engineer Manual (EM) 1110-2-1906, Appendix II. Washington, DC.

U.S. Department of Energy. 1992. Environmental Measurements Laboratory Procedures Manual, HASL-300, 27th Edition, Volume 1. New York, NY.

U.S. Department of Energy, Nevada Operations Office. 1996a. Corrective Action Unit Work Plan Tonopah Test Range. Las Vegas, NV: IT Corporation.

U.S. Department of Energy, Nevada Operations Office. 1996b. Industrial Sites Quality Assurance Project Plan, Nevada Test Site, Nevada, Rev. 1. Las Vegas, NV.

U.S. Department of Energy, Nevada Operations Office. 1997a. Corrective Action Investigation Plan for CAU No. 427: Area 3 Septic Waste System Numbers 2 \& 6, Tonopah Test Range, Nevada, DOE/NV-488, UC-700. Las Vegas, NV: IT Corporation.

U.S. Department of Energy, Nevada Operations Office. 1997b. Final, Initial Surface Geophysical Survey Report for the Tonopah Test Range Environmental Restoration Sites, DOE/NV-10972-93. Las Vegas, NV: IT Corporation.

U.S. Department of Energy, Nevada Operations Office. 1998. Final, Corrective Action Decision Document for the Area 3 Landfill Complex, Tonopah Test Range, CAU 424, DOE/NV-496 UC-700, Rev. 0. Las Vegas, NV: IT Corporation.

U.S. Environmental Protection Agency. 1987. Data Quality Objectives for Remedial Response Activities, EPA/540/G-87-003. Washington, DC.

U.S. Environmental Protection Agency. 1994a. Guidance for the Data Quality Objectives Process, EPA QA/G-4. Washington, DC.

U.S. Environmental Protection Agency. 1994b. Contract Laboratory Program National Functional Guidelines for Organic Data Review, EPA 540/R-94/012. Washington, DC.

U.S. Environmental Protection Agency. 1994c. Contract Laboratory Program National Functional Guidelines for Inorganic Data Review, EPA 540/R-94/013. Washington, DC.

U.S. Environmental Protection Agency. 1996a. Memo from S.J. Smucker to PRG Table Mailing List regarding Region 9 Preliminary Remediation Goals (PRGs), 1 August. San Francisco, CA.

U.S. Environmental Protection Agency. 1996b. Test Methods for Evaluating Solid Waste, Physical/Chemical Methods, SW-846, CD ROM. Washington, DC. 


\section{Attachment 1 Geotechnical Data}




\section{Converse Consultants Southwest, Inc. \\ Moisture - Density - Porosity Determinations}

\section{MOISTURE CALCULATIONS}

\begin{tabular}{|l|c|c|c|}
\hline Boring No. and Depth & 909 & 935 & 967 \\
\hline Wt of samp + Dish (wet) & 379.4 & 1815.7 & 1353.7 \\
\hline Wt of samp + Dish (dry) & 363.4 & 1644.2 & 1283.2 \\
\hline Wt. of Moisture & 16 & 171.5 & 70.5 \\
\hline Wt. of Dish & 169.5 & 170.2 & 161.6 \\
\hline Dry Wt. & 193.9 & 1474 & 1121.6 \\
\hline Moisture \% & $8.3 \%$ & $11.6 \%$ & $6.3 \%$ \\
\hline Plasticity Index & ${ }^{*} \mathrm{NP}$ & 6 & ${ }^{*} \mathrm{NP}$ \\
\hline
\end{tabular}

*non-plastic

\section{DENSITY CALCULATIONS}

\begin{tabular}{|l|c|c|c|}
\hline Length of Sample (inches) & 2.735 & 5.867 & 5.412 \\
\hline Sample Diameter (inches) & 1.924 & 3.350 & 3.365 \\
\hline Volume of Sample $\left(\mathrm{ft}^{3}\right)$ & 0.0046 & 0.0299 & 0.0279 \\
\hline Wet Density & 100.6 & 121.2 & 94.4 \\
\hline Dry Density & 92.9 & 108.6 & 88.8 \\
\hline
\end{tabular}

POROSITY CALCULATIONS

\begin{tabular}{|l|l|l|l|}
\hline Assumed Specific Gravity, $\mathrm{G}_{\mathbf{s}}$ & 2.65 & 2.65 & 2.65 \\
\hline Void Ratio, $\mathrm{e}$ & 0.78 & 0.52 & 0.86 \\
\hline Porosity, $\mathrm{n}$ & 0.44 & 0.34 & 0.46 \\
\hline
\end{tabular}




\section{HYDROMETER ANALYSIS}

Project Name: IT Corporation

Project No.: 96-33699-01

Sample No.: \#909

\begin{tabular}{r|r|}
\hline Tare No: & \\
Wt of wet soil + tare: & 1.00 \\
& 1.00 \\
\hline Wt of Tare: & 0.00 \\
Wt. of Water: & 0.00 \\
Wt. of Dry Soil: & 1.00 \\
\hline Moisture Content: & 0.0 \\
\hline
\end{tabular}

Hygroscopic Moisture Correction Factor

Moisture Content:
Boring No::
Prepared By: NER

Tested By: NER

Date tested: $01 / 01 / 98$

Depth:

Soil Description:

\begin{tabular}{|c|c|c|c|c|c|c|c|c|c|c|}
\hline Time. & Temp. ${ }^{\circ} \mathrm{C}$ & Hydor. Rdg. & Correction & $\begin{array}{c}\text { Corrected } \\
\text { Reading } \\
R_{1}-C\end{array}$ & $\mid \begin{array}{c}\text { Values of } \mathrm{K} \\
\text { From Table } 3\end{array}$ & $\begin{array}{c}\text { Effective } \\
\text { Depth } \\
\text { From } \\
\text { Table 2 }\end{array}$ & & $\begin{array}{c}\text { Effective } \\
\text { Particle } \\
\text { Diameter } \\
\text { (mm) }\end{array}$ & $\begin{array}{c}\text { Soil in Susp. \% } \\
(\mathrm{Ra} / \mathrm{W}) \times 100\end{array}$ & $\begin{array}{c}\text { Percent of total } \\
\text { Passing } \\
P \times P \%\end{array}$ \\
\hline$t$ & $\mathbf{T}$ & $R_{1}$ & C & $\mathbf{R}$ & $K$ & $\mathbf{L}$ & $\mathrm{L} / \mathrm{t}$ & D & $\mathbf{P}$ & $P^{\prime}$ \\
\hline 1 & 22 & 21 & 5 & 16 & 0.01332 & 12.9 & 12.9000 & 0.04784 & 15.9 & 6.0 \\
\hline 2 & 22 & 20 & 5 & 15 & 0.01332 & 13 & 6.5000 & 0.03396 & 14.9 & 5.7 \\
\hline 4 & 22 & 19 & 5 & 14 & 0.01332 & 13.2 & 3.3000 & 0.02420 & 13.9 & 5.3 \\
\hline 8 & 22 & 18 & 5 & 13 & 0.01332 & 13.3 & 1.6625 & 0.01717 & 12.9 & 4.9 \\
\hline 15 & 22 & 17.5 & 5 & 12.5 & 0.01332 & 13.5 & 0.9000 & 0.01264 & 12.4 & 4.7 \\
\hline 30 & 22 & 16 & 5 & 11 & 0.01332 & 13.7 & 0.4567 & 0.00900 & 10.9 & 4.1 \\
\hline $60^{\circ}$ & 22 & 14 & 5 & 9 & 0.01332 & 14 & 0.2333 & 0.00643 & 8.9 & 3.4 \\
\hline 250 & 21 & 12.5 & 5 & 7.5 & 0.01348 & 14.3 & 0.0572 & 0.00322 & 7.4 & 2.8 \\
\hline 372 & 21 & 12 & 5 & 7 & 0.01348 & 14.3 & 0.0384 & 0.00264 & 6.9 & 2.6 \\
\hline 1257 & 21 & 11 & 5 & 6 & 0.01348 & 14.5 & 0.0115 & 0.00145 & 6.0 & 2.3 \\
\hline 1404 & 21 & 10 & 5 & 5 & 0.01348 & 14.7 & 0.0105 & 0.00138 & 5.0 & 1.9 \\
\hline
\end{tabular}




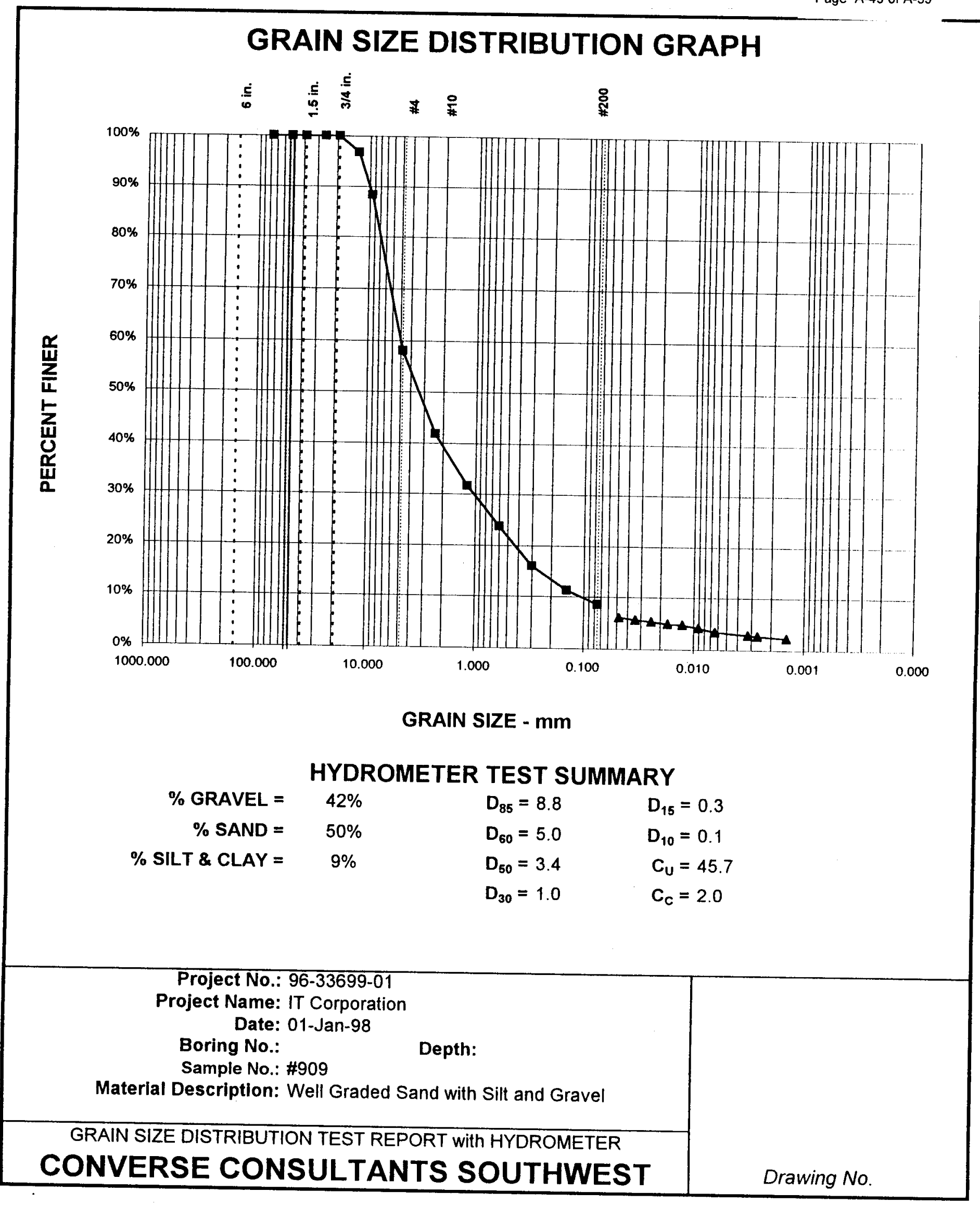




\section{FLEXIBLE WALL HYDRAULIC CONDUCTIVITY TEST ASTM D5084}

$\begin{array}{ll}\text { Project Name: } & \text { Industrial Sites } \\ \text { Project No:: } & \text { T72848.05020300 } \\ \text { Location: } & \text { SWS2AND6 } \\ \text { Sample No:: } & \text { TTR00909 Depth: feet } \\ \text { Soil Description: } & \text { Lt Brn F-C Sand with gravel } \\ & \text { Test Condition: }\end{array}$

\begin{tabular}{rr} 
Tested by & $\mathrm{AP}$ \\
$\begin{array}{r}\text { Calculated by } \\
\text { Checked by }\end{array} \quad \mathrm{AP}$ \\
\hline
\end{tabular}

$\begin{array}{ll}\text { Date } & 01 / 16 / 98 \\ \text { Date } & 01 / 20 / 98 \\ \text { Date } & 01 / 20 / 98\end{array}$

\section{INITIAL CONDITION OF SPECIMEN}

Diameter (d)

Sample Area (A)

Length ( $L$ )

Weight Before

Wet Density

Dry Density

\begin{tabular}{rl}
1.915 & in \\
\hline 2.88 & in $^{2}$ \\
\hline 2.70 & in \\
\hline 228.08 & $\mathrm{~g}$
\end{tabular}

pcf pcf

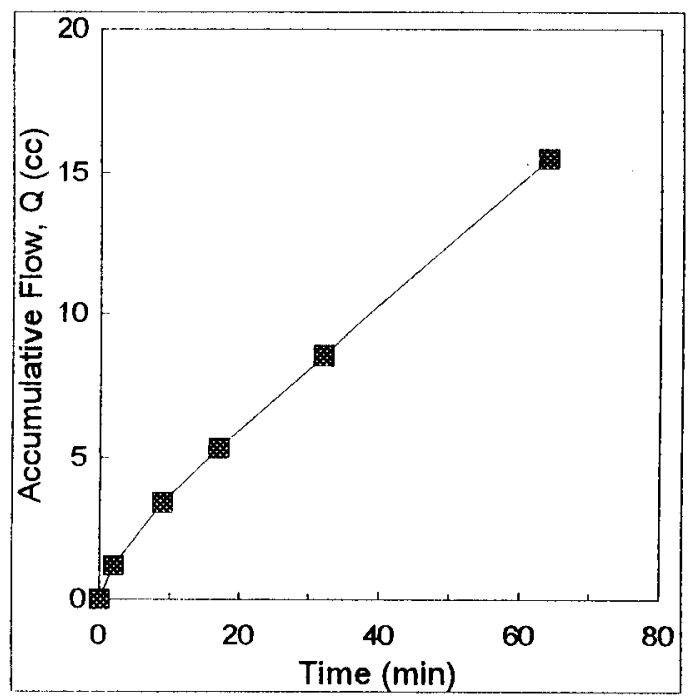

Container No.

Wt. Wet Soil+Container(gms)

Wt. Dry Soil+Container(gms)

Wt. Container (gms)

Moisture, (\%)

$\begin{array}{r}\text { Before } \\ \hline 228.08 \\ \hline 207.37 \\ \hline 0 \\ \hline 10.0 \\ \hline\end{array}$

\section{TEST RESULTS}

\begin{tabular}{|c|c|c|c|c|c|c|}
\hline $\begin{array}{c}\text { Time } \\
(\mathrm{min})\end{array}$ & $\begin{array}{c}\text { Flow Rdg } \\
(\mathrm{cm})\end{array}$ & $\begin{array}{c}\text { Burette } \\
\text { Factor }\end{array}$ & $\begin{array}{c}\mathrm{Q} \\
(\mathrm{cc})\end{array}$ & $\begin{array}{c}\text { Head, } \mathrm{h} \\
(\mathrm{psi})\end{array}$ & $\mathrm{h} / \mathrm{L}$ & $\begin{array}{c}\mathrm{Q} / \mathrm{t} \\
(\mathrm{cc} / \mathrm{s})\end{array}$ \\
\hline 0 & 34.0 & 1 & 0.0 & 2.0 & 20.5 & 0.000000 \\
\hline 2 & 32.8 & 1 & 1.2 & 2.0 & 20.5 & 0.010000 \\
\hline 9 & 30.6 & 1 & 3.4 & 2.0 & 20.5 & 0.005238 \\
\hline 17 & 28.7 & 1 & 5.3 & 2.0 & 20.5 & 0.003958 \\
\hline 32 & 25.4 & 1 & 8.6 & 2.0 & 20.5 & 0.003667 \\
\hline 64 & 18.5 & 1 & 15.5 & 2.0 & 20.5 & 0.003594 \\
\hline & & & & & & \\
\hline & & & & & & \\
\hline & & & & & & \\
\hline
\end{tabular}


Project Name: Industrial Sites

Project No.: $\quad 772848.05020300$

Location.: SWS2AND

Sample No: $\quad$ TTR00909 Depth: n/a

Soil Type:
Tested By: JT Date: 01/08/98

Checked By: AP Date: 01/20/98

Initial Moisture Content (\%): $\quad 12.47$

Initial Unit Weight (pcf):

92.7

Sample Diameter (in):

1.89

Sample Height (in):

0.4

\begin{tabular}{|l|r|r|r|r|r|r|r|r|r|}
\hline Tension (bars) & 0 & 0.1 & 0.3 & 0.5 & 1 & 2.5 & 5 & 10 & 15 \\
\hline Tension (feet of water) & 0 & 3.4 & 8.5 & 17 & 33.9 & 84.8 & 169.5 & 339 & 508.5 \\
\hline Moisture Content by Wt (\%) & 28.85 & 18.44 & 18.07 & 17.41 & 17.12 & 16.46 & 16.20 & 15.85 & 15.25 \\
\hline Cor. Dry Unit Wt of Soil (pcf) & 92.70 & 86.80 & 86.80 & 86.80 & 86.80 & 86.80 & 86.80 & 86.80 & 86.80 \\
\hline Moisture Content by Vol(\%) & 42.84 & 27.38 & 26.83 & 25.85 & 25.42 & 24.44 & 24.05 & 23.54 & 22.64 \\
\hline
\end{tabular}

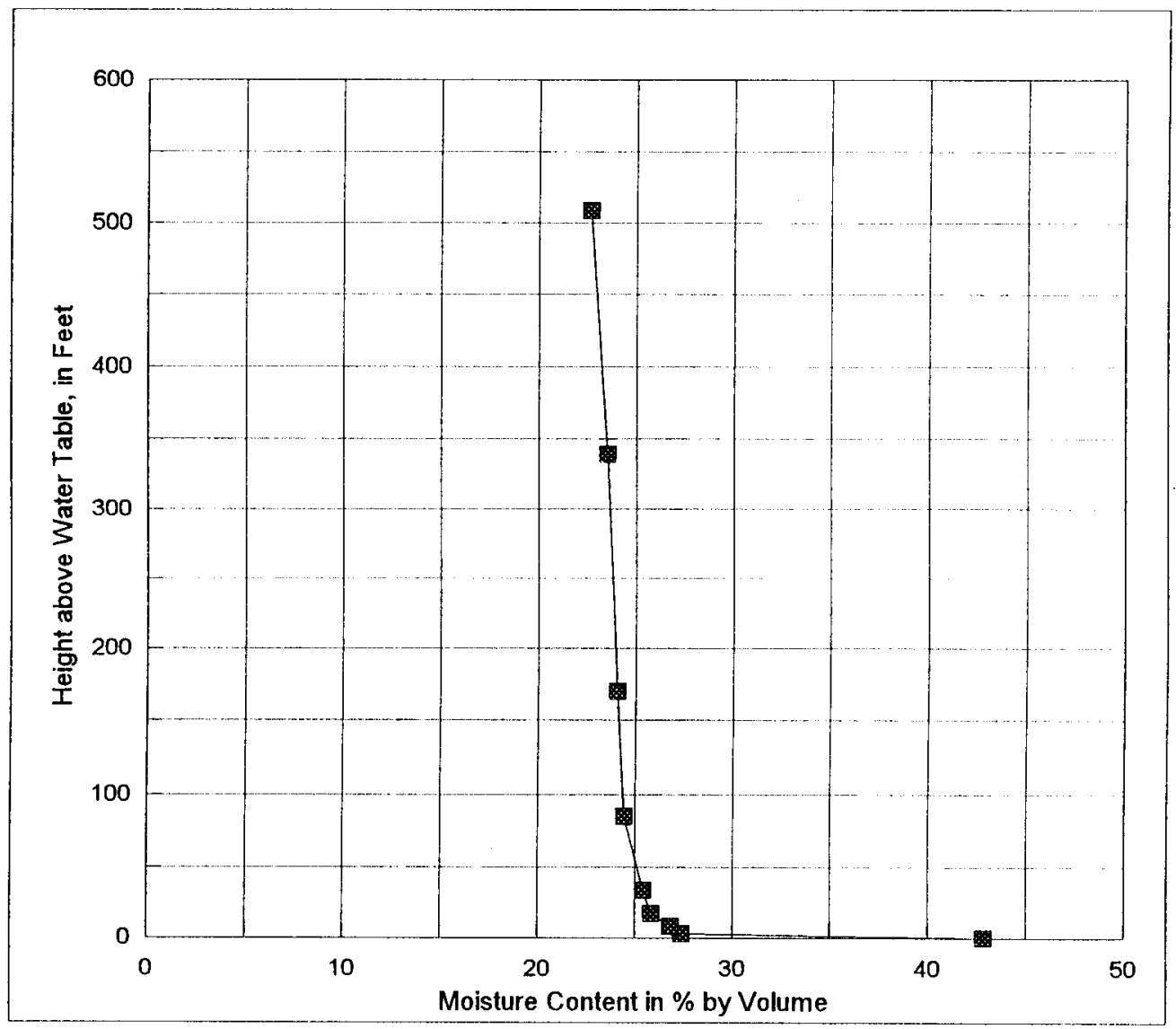

Wilting Point:

Field Capacity: 26.8 


\section{HYDROMETER ANALYSIS \\ Date: 06/24/98 \\ Page $A-52$ of $A-59$}

Project Name: IT Corporation

Project No.: 96-33699-01

Sample No.:

Boring No.: TTR00935
Prepared By: NER

Tested By: NER

Date tested: $1 / 98$

Depth:

\section{$\square$ Oven Dry $\square$ Air Dry}

Hygroscopic Moisture Correction Factor

\begin{tabular}{|c|c|}
\hline Tare No: & \\
\hline Wt of wet soil + tare: & 1.00 \\
\hline Wt of dry soil + tare: & 1.00 \\
\hline Wt of Tare: & 0.00 \\
\hline Wt. of Water: & 0.00 \\
\hline Wt. of Dry Soil: & 1.00 \\
\hline Moisture Content: & 0.0 \\
\hline
\end{tabular}

Soil Description: Clayey Sand with Gravel

\begin{tabular}{|c|c|c|c|c|c|c|c|c|c|c|}
\hline Time. & Temp. ${ }^{\circ} \mathrm{C}$ & Hydor. Rdg. & Correction & $\begin{array}{l}\text { Correcled } \\
\text { Reading } \\
R_{1}-C\end{array}$ & $\begin{array}{c}\text { Values of K } \\
\text { From Table } 3\end{array}$ & $\begin{array}{l}\text { Effoctive } \\
\text { Depth } \\
\text { From } \\
\text { Table 2 }\end{array}$ & & $\begin{array}{c}\text { Effective } \\
\text { Particle } \\
\text { Diameler } \\
(\mathrm{mm})\end{array}$ & $\begin{array}{c}\text { Soil in Susp. } \% \\
(\operatorname{Ra} M) \times 100\end{array}$ & $\begin{array}{l}\text { Percent of tolal } \\
\text { Passing } \\
P \times P \%\end{array}$ \\
\hline$t$ & $T$ & $\mathbf{R}_{1}$ & c & $\mathbf{R}$ & $K$ & $\mathbf{L}$ & Lt & D & $\mathbf{P}$ & $\mathbf{P}^{\prime}$ \\
\hline 1 & 22 & 24 & 5 & 19 & 0.01332 & 12.4 & 12.4000 & 0.04690 & 23.5 & 13.7 \\
\hline 2 & 22 & 22 & 5 & 17 & 0.01332 & 12.7 & 6.3500 & 0.03357 & 21.1 & 12.2 \\
\hline 4 & 22 & 21 & 5 & 16 & 0.01332 & 12.9 & 3.2250 & 0.02392 & 19.8 & 11.5 \\
\hline 8 & 22 & 19.5 & 5 & 14.5 & 0.01332 & 13.2 & 1.6500 & 0.01711 & 18.0 & 10.4 \\
\hline 15 & 22 & 18 & 5 & 13 & 0.01332 & 13.3 & 0.8867 & 0.01254 & 16.1 & 9.3 \\
\hline 30 & 22 & 17 & 5 & 12 & 0.01332 & 13.5 & 0.4500 & 0.00894 & 14.9 & 8.6 \\
\hline 60 & 22 & 15 & 5 & 10 & 0.01332 & 13.8 & 0.2300 & 0.00639 & 12.4 & 7.2 \\
\hline 250 & 21 & 13 & 5 & 8 & 0.01348 & 14.2 & 0.0568 & 0.00321 & 9.9 & 5.7 \\
\hline 473 & 21 & 13 & 5 & 8 & 0.01348 & 14.2 & 0.0300 & 0.00234 & 9.9 & 5.7 \\
\hline 1440 & 21 & 10 & 5 & 5 & 0.01348 & 14.7 & 0.0102 & 0.00136 & 6.2 & 3.6 \\
\hline
\end{tabular}




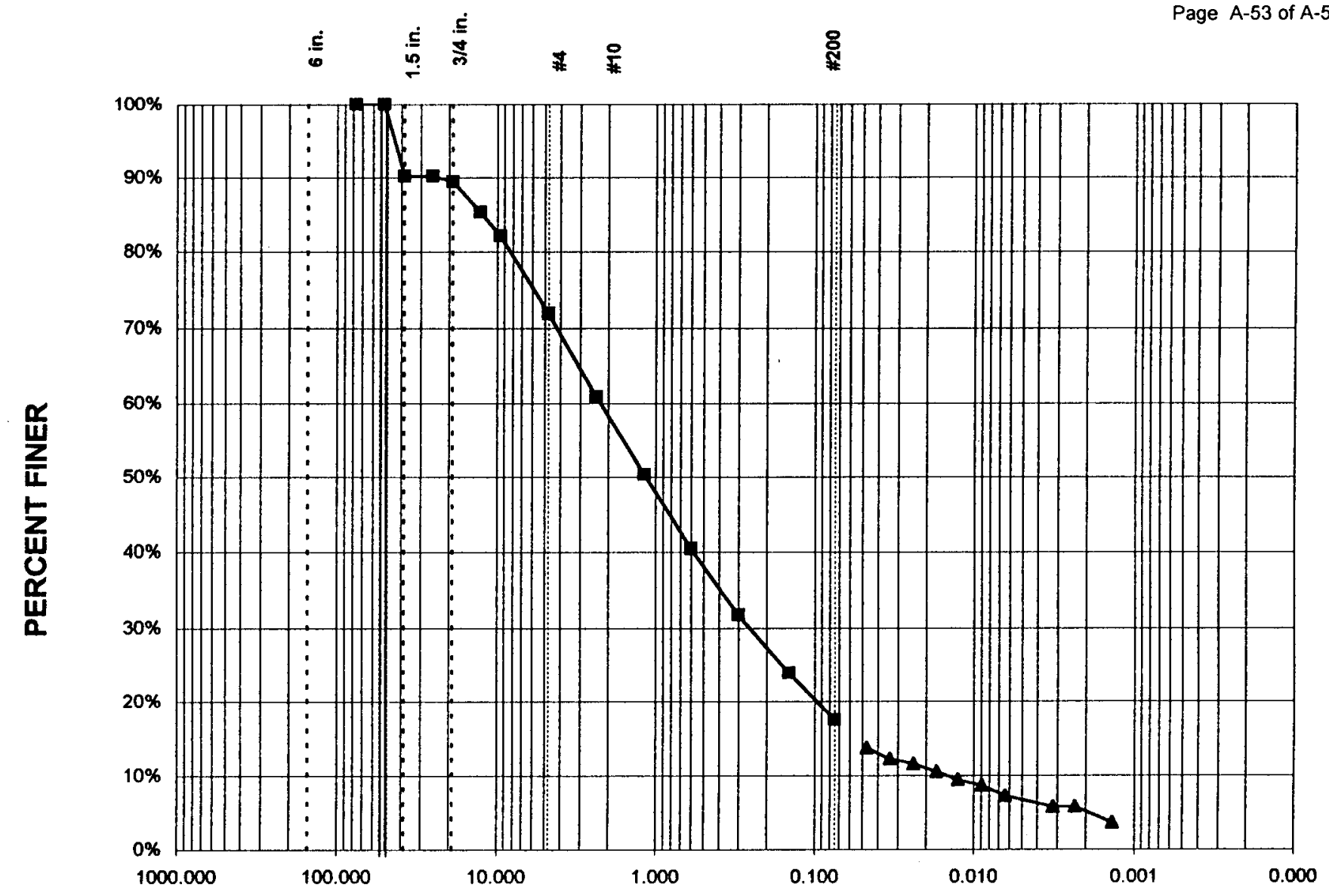

GRAIN SIZE - mm

HYDROMETER TEST SUMMARY

$\begin{array}{rlll}\% \text { GRAVEL }= & 28 \% & D_{85}=12.5 & D_{15}= \\ \% \text { SAND }= & 54 \% & D_{60}=2.2 & D_{10}= \\ \text { SILT \& CLAY }= & 18 \% & D_{50}=1.2 & C_{U}= \\ & & D_{30}=0.3 & C_{C}=\end{array}$

Project No.: 96-33699-01

Project Name: IT Corporation

Date: $1 / 98$

Boring No.: TTR00935 Depth:

Sample No::

Material Description: Clayey Sand with Gravel

GRAIN SIZE DISTRIBUTION TEST REPORT with HYDROMETER 


\section{FLEXIBLE WALL HYDRAULIC CONDUCTIVITY TEST \\ ASTM D5084}

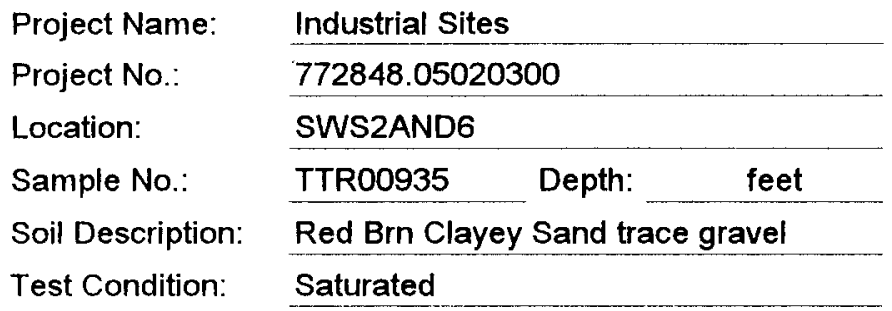

\begin{tabular}{rr} 
Tested by & AP \\
\cline { 2 - 2 } Calculated by & AP \\
Checked by & AP \\
\hline
\end{tabular}

Date $\quad 01 / 16 / 98$

Date $01 / 20 / 98$

Date $\quad 01 / 20 / 98$

\section{INITIAL CONDITION OF SPECIMEN}

\begin{tabular}{lrr} 
Diameter (d) & 2.875 & in \\
\cline { 2 - 2 } Sample Area (A) & in \\
Length (L) & 6.49 & in \\
Weight Before & 520.85 & g \\
\cline { 2 - 2 } $\begin{array}{l}\text { Wet Density } \\
\text { Dry Density }\end{array}$ & 129.4 & pcf \\
\cline { 2 - 2 } & 113.4 & pcf
\end{tabular}

Container No.

Wt. Wet Soil+Container(gms)

$\begin{array}{r}\text { Before } \\ \hline 258.37 \\ \hline 230.57 \\ \hline 34.49 \\ \hline 14.2 \\ \hline\end{array}$

$\begin{array}{r}\text { After } \\ \hline 716.95 \\ \hline 653.17 \\ \hline 196.22 \\ \hline 14.0 \\ \hline\end{array}$

\section{TEST RESULTS}

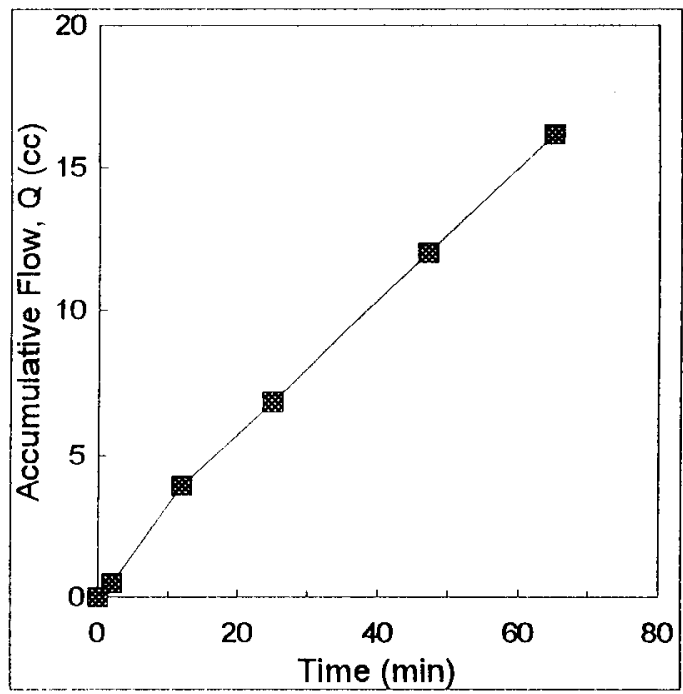

\begin{tabular}{|c|c|c|c|c|c|c|}
\hline $\begin{array}{l}\text { Time } \\
\text { (min) }\end{array}$ & $\begin{array}{c}\text { Flow Rdg } \\
(\mathrm{cm})\end{array}$ & $\begin{array}{l}\text { Burette } \\
\text { Factor }\end{array}$ & $\begin{array}{c}Q \\
(c c)\end{array}$ & $\begin{array}{c}\text { Head, h } \\
\text { (psi) }\end{array}$ & $h / L$ & $\begin{array}{c}\mathrm{Q} / \mathrm{t} \\
(\mathrm{cc} / \mathrm{s})\end{array}$ \\
\hline 0 & 7.4 & 2.449 & 0.0 & 3.0 & 35.2 & 0.000000 \\
\hline 2 & 7.6 & 2.449 & 0.5 & 3.0 & 35.2 & 0.004082 \\
\hline 12 & 9.0 & 2.449 & 3.9 & 3.0 & 35.2 & 0.005714 \\
\hline 25 & 10.2 & 2.449 & 6.9 & 3.0 & 35.2 & 0.003768 \\
\hline 47 & 12.3 & 2.449 & 12.0 & 3.0 & 35.2 & 0.003896 \\
\hline 65 & 14.0 & 2.449 & 16.2 & 3.0 & 35.2 & 0.003855 \\
\hline & & & & & & \\
\hline & & & & & & \\
\hline & & & & & & \\
\hline
\end{tabular}




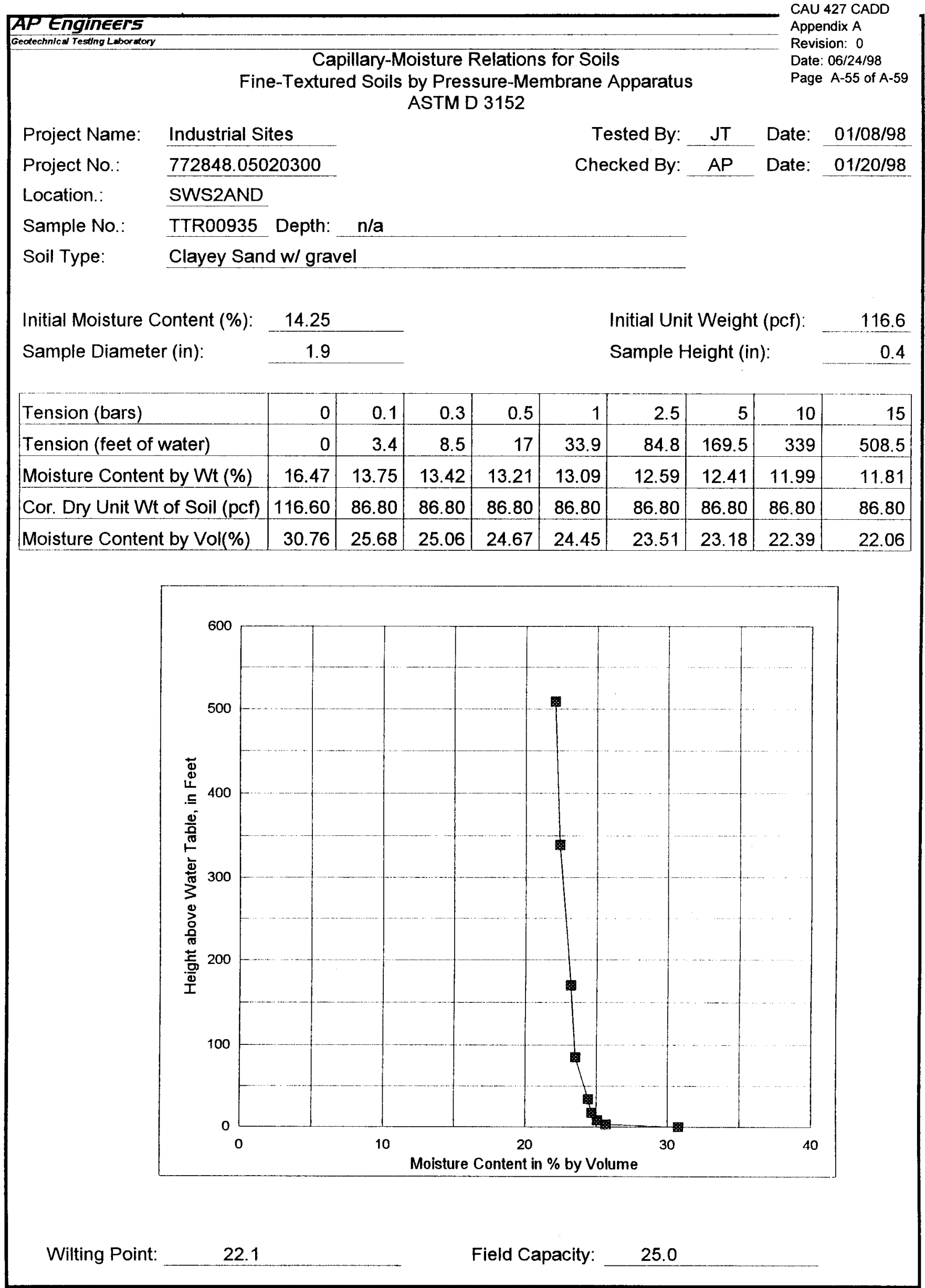




\section{HYDROMETER ANALYSIS \\ Page A-56 of A-59}

Project Name: 1T Corporation

Project No.: 96-33699-01

Sample No.: \#967
Boring No:
Prepared By: NER

Tested By: NER

Date tested: $01 / 01 / 98$

Depth:
Hygroscopic Moisture Correction Factor

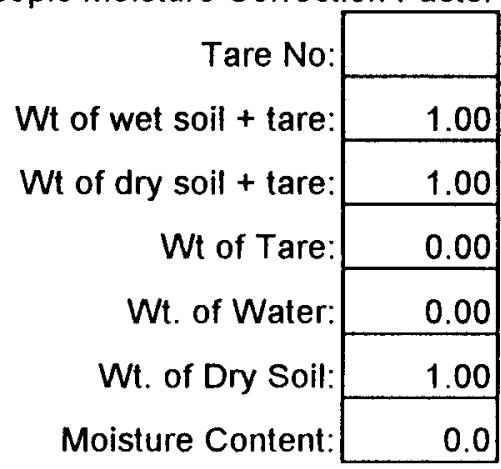

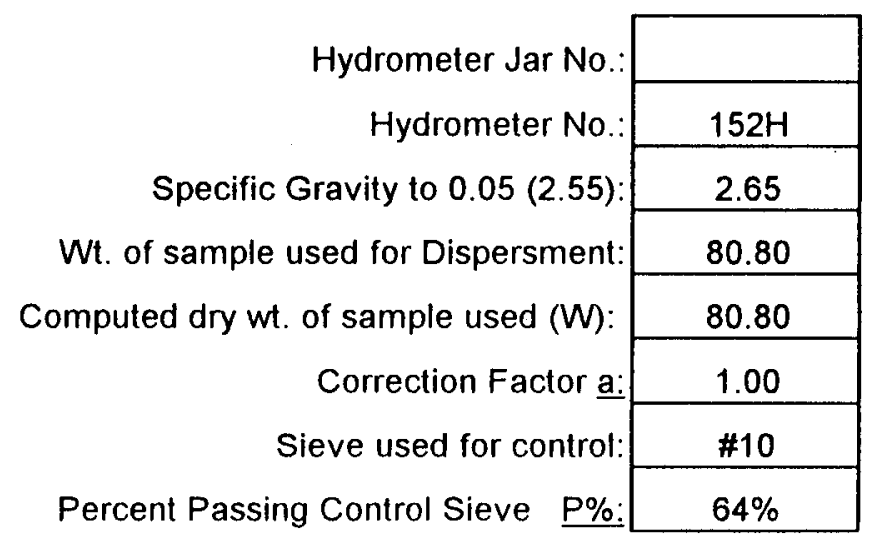

Soil Description:

\begin{tabular}{|c|c|c|c|c|c|c|c|c|c|c|}
\hline Time. & Temp. ${ }^{\circ} \mathrm{C}$ & Hydor. Rdg. & Correction & $\begin{array}{c}\text { Corrected } \\
\text { Reading } \\
R_{1}-C\end{array}$ & $\mid \begin{array}{c}\text { Values of K } \\
\text { From Table } 3\end{array}$ & $\begin{array}{l}\text { Eflective } \\
\text { Depth } \\
\text { From } \\
\text { Table 2 }\end{array}$ & & $\begin{array}{c}\text { Eflective } \\
\text { Particle } \\
\text { Diameler } \\
(\mathrm{mm})\end{array}$ & $\begin{array}{c}\text { Soil in Susp. \% } \\
(\operatorname{Ra} / W) \times 100\end{array}$ & $\begin{array}{l}\text { Percent of tota } \\
\text { Passing } \\
\text { P } \times \text { P\% }\end{array}$ \\
\hline$t$ & $\mathbf{T}$ & $\mathbf{R}_{1}$ & c & $\mathbf{R}$ & K & $\mathbf{L}$ & $\mathrm{Lt}$ & D & $\mathbf{P}$ & $P^{\prime}$ \\
\hline 1 & 22 & 13 & 5 & 8 & 0.01332 & 14.2 & 14.2000 & 0.05019 & 9.9 & 6.3 \\
\hline 2 & 22 & 11.5 & 5 & 6.5 & 0.01332 & 14.5 & 7.2500 & 0.03587 & 8.0 & 5.1 \\
\hline 4 & 22 & 10.5 & 5 & 5.5 & 0.01332 & 14.7 & 3.6750 & 0.02553 & 6.8 & 4.4 \\
\hline 8 & 22 & 10 & 5 & 5 & 0.01332 & 14.7 & 1.8375 & 0.01806 & 6.2 & 4.0 \\
\hline 15 & 22 & 9 & 5 & 4 & 0.01332 & 14.8 & 0.9867 & 0.01323 & 5.0 & 3.2 \\
\hline 30 & 22 & 8 & 5 & 3 & 0.01332 & 15 & 0.5000 & 0.00942 & 3.7 & 2.4 \\
\hline 60 & 22 & 7.5 & 5 & 2.5 & 0.01332 & 15.2 & 0.2533 & 0.00670 & 3.1 & 2.0 \\
\hline 250 & 21 & 6 & 5 & 1 & 0.01348 & 15.3 & 0.0612 & 0.00333 & 1.2 & 0.8 \\
\hline 393 & 21 & 6 & 5 & 1 & 0.01348 & 15.3 & 0.0389 & 0.00266 & 1.2 & 0.8 \\
\hline 1278 & 21 & 6 & 5 & 1 & 0.01348 & 15.3 & 0.0120 & 0.00147 & 1.2 & 0.8 \\
\hline 1420 & 21 & 5 & 5 & 0 & 0.01348 & 15.5 & 0.0109 & 0.00141 & 0.0 & 0.0 \\
\hline
\end{tabular}




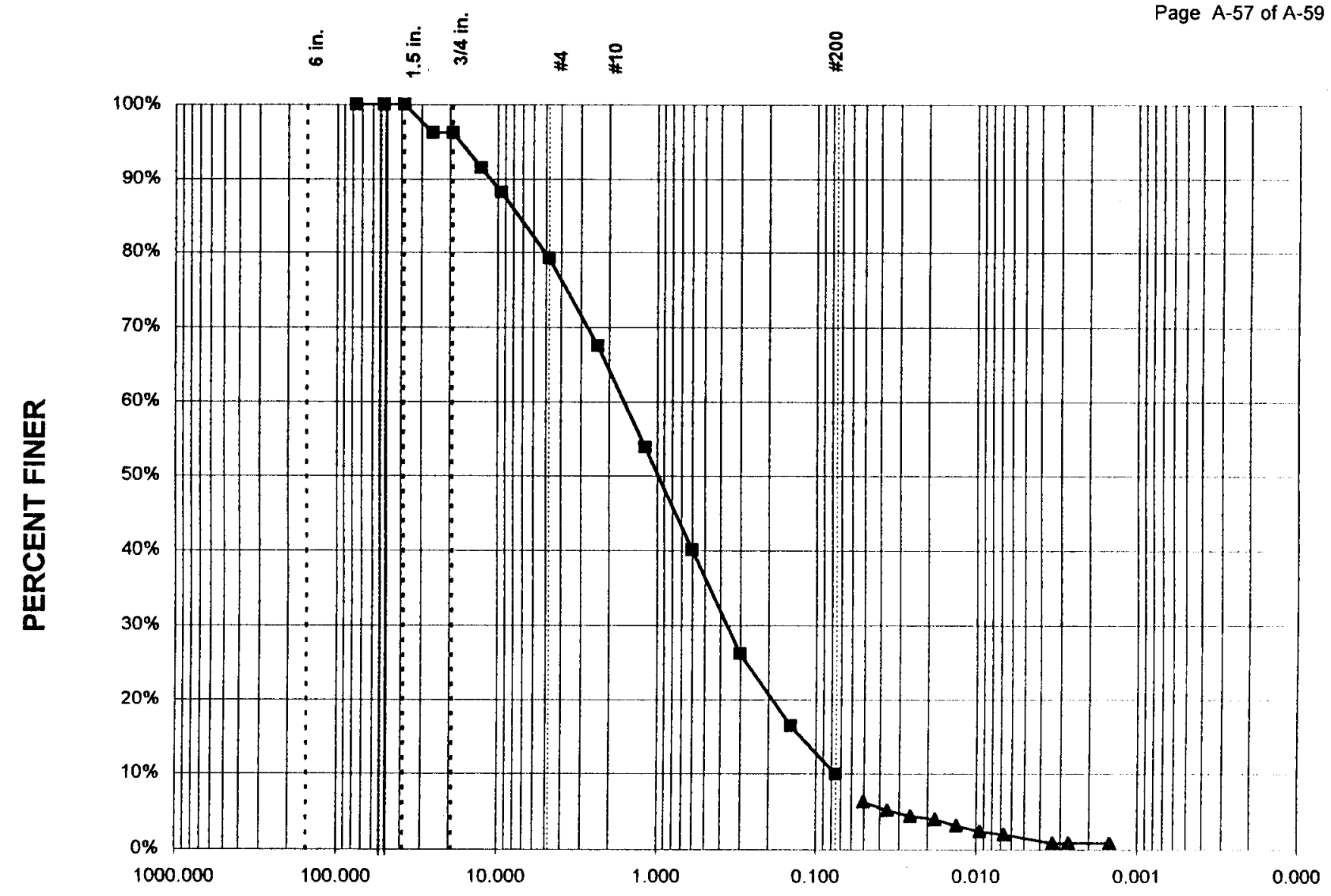

GRAIN SIZE - mm

\section{HYDROMETER TEST SUMMARY}

$\begin{array}{rlll}\% \text { GRAVEL }= & 21 \% & D_{85}=7.4 & D_{15}=0.1 \\ \% \text { SAND }= & 69 \% & D_{60}=1.6 & D_{10}=0.1 \\ \% \text { SILT \& CLAY }= & 10 \% & D_{50}=1.0 & C_{U}=21.3 \\ & & D_{30}=0.4 & C_{C}=1.1\end{array}$

Project No.: 96-33699-01

Project Name: IT Corporation

Date: $01-J a n-98$

Boring No.:

Sample No.: \#967

Depth:

Material Description: Well Graded Sand with Silt and Gravel

GRAIN SIZE DISTRIBUTION TEST REPORT with HYDROMETER

CONVERSE CONSULTANTS SOUTHWEST

Drawing No. 


\section{FLEXIBLE WALL HYDRAULIC CONDUCTIVITY TEST ASTM D5084}

Project Name: Industrial Sites

Project No: $\quad 772848.05020300$

Location: $\quad$ SWS2AND6

Sample No:: TTR00967 Depth: feet

Soil Description: Red Brn F-C Sand trace gravel

Test Condition: Saturated

\begin{tabular}{|c|c|c|c|}
\hline Tested by & AP & Date & $01 / 16 / 98$ \\
\hline Calculated by & AP & Date & $01 / 20 / 98$ \\
\hline Checked by & AP & Date & $01 / 20 / 98$ \\
\hline
\end{tabular}

\section{INITIAL CONDITION OF SPECIMEN}

Diameter (d)

Sample Area (A)

Length $(L)$

Weight Before

Wet Density

Dry Density

\begin{tabular}{rl}
2.875 & in \\
\hline 6.49 & in $^{2}$ \\
\hline 2.36 & in \\
\hline 449.32 & $\mathrm{~g}$
\end{tabular}

111.7 102.0 pcf pef

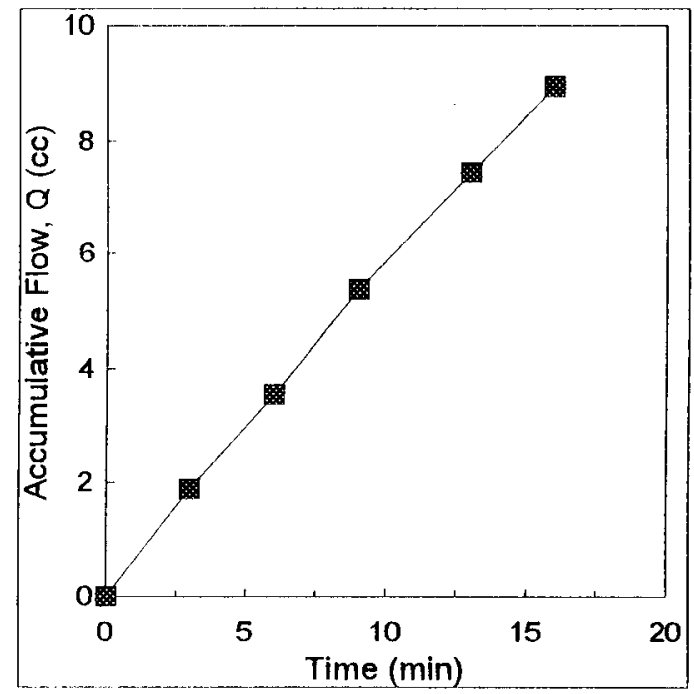

Container No.

Wt. Wet Soil+Container(gms)

Wt. Dry Soil+Container(gms)

Wt. Container (gms)

Moisture, (\%)

\begin{tabular}{|c|c|}
\hline Before & After \\
\hline 190.4 & 332.82 \\
\hline 176.99 & 282.08 \\
\hline 34.6 & 35.04 \\
\hline 9.4 & 20.5 \\
\hline
\end{tabular}

\section{TEST RESULTS}

\begin{tabular}{|c|c|c|c|c|c|c|}
\hline $\begin{array}{l}\text { Time } \\
(\mathrm{min})\end{array}$ & $\begin{array}{c}\text { Flow Rdg } \\
(\mathrm{cm})\end{array}$ & $\begin{array}{c}\text { Burette } \\
\text { Factor }\end{array}$ & $\begin{array}{c}Q \\
(c c)\end{array}$ & $\begin{array}{c}\text { Head, h } \\
\text { (psi) }\end{array}$ & $h / L$ & $\begin{array}{c}Q / t \\
(\mathrm{cc} / \mathrm{s})\end{array}$ \\
\hline 0 & 2.1 & 0.474 & 0.0 & 3.0 & 35.2 & 0.000000 \\
\hline 3 & 6.1 & 0.474 & 1.9 & 3.0 & 35.2 & 0.010533 \\
\hline 6 & 9.6 & 0.474 & 3.6 & 3.0 & 35.2 & 0.009217 \\
\hline 9 & 13.4 & 0.474 & 5.4 & 3.0 & 35.2 & 0.010007 \\
\hline 13 & 17.8 & 0.474 & 7.4 & 3.0 & 35.2 & 0.008690 \\
\hline 16 & 21.0 & 0.474 & 9.0 & 3.0 & 35.2 & 0.008427 \\
\hline & & & & & & \\
\hline & & & & & & \\
\hline & & & & & & \\
\hline
\end{tabular}


Project Name: Industrial Sites

Project No: $\quad 772848.05020300$

Location.: SWS2AND

Sample No.: $\quad$ TTR00967 Depth: n/a

Soil Type: $\quad$ SP

Initial Moisture Content (\%): $\quad 10.35$

1.9

Sample Diameter (in):
Tested By: _ JT

Date: $\quad 01 / 08 / 98$

Checked By: AP Date: 01/20/98

Initial Unit Weight (pcf):

95.4

\begin{tabular}{|l|r|r|r|r|r|r|r|r|r|}
\hline Tension (bars) & 0 & 0.1 & 0.3 & 0.5 & 1 & 2.5 & 5 & 10 & 15 \\
\hline Tension (feet of water) & 0 & 3.4 & 8.5 & 17 & 33.9 & 84.8 & 169.5 & 339 & 508.5 \\
\hline Moisture Content by Wt (\%) & 24.64 & 12.61 & 11.44 & 10.91 & 10.69 & 10.09 & 9.91 & 9.63 & 9.48 \\
\hline Cor. Dry Unit Wt of Soil (pcf) & 95.40 & 86.80 & 86.80 & 86.80 & 86.80 & 86.80 & 86.80 & 86.80 & 86.80 \\
\hline Moisture Content by Vol(\%) & 37.65 & 19.27 & 17.48 & 16.67 & 16.34 & 15.42 & 15.14 & 14.72 & 14.49 \\
\hline
\end{tabular}

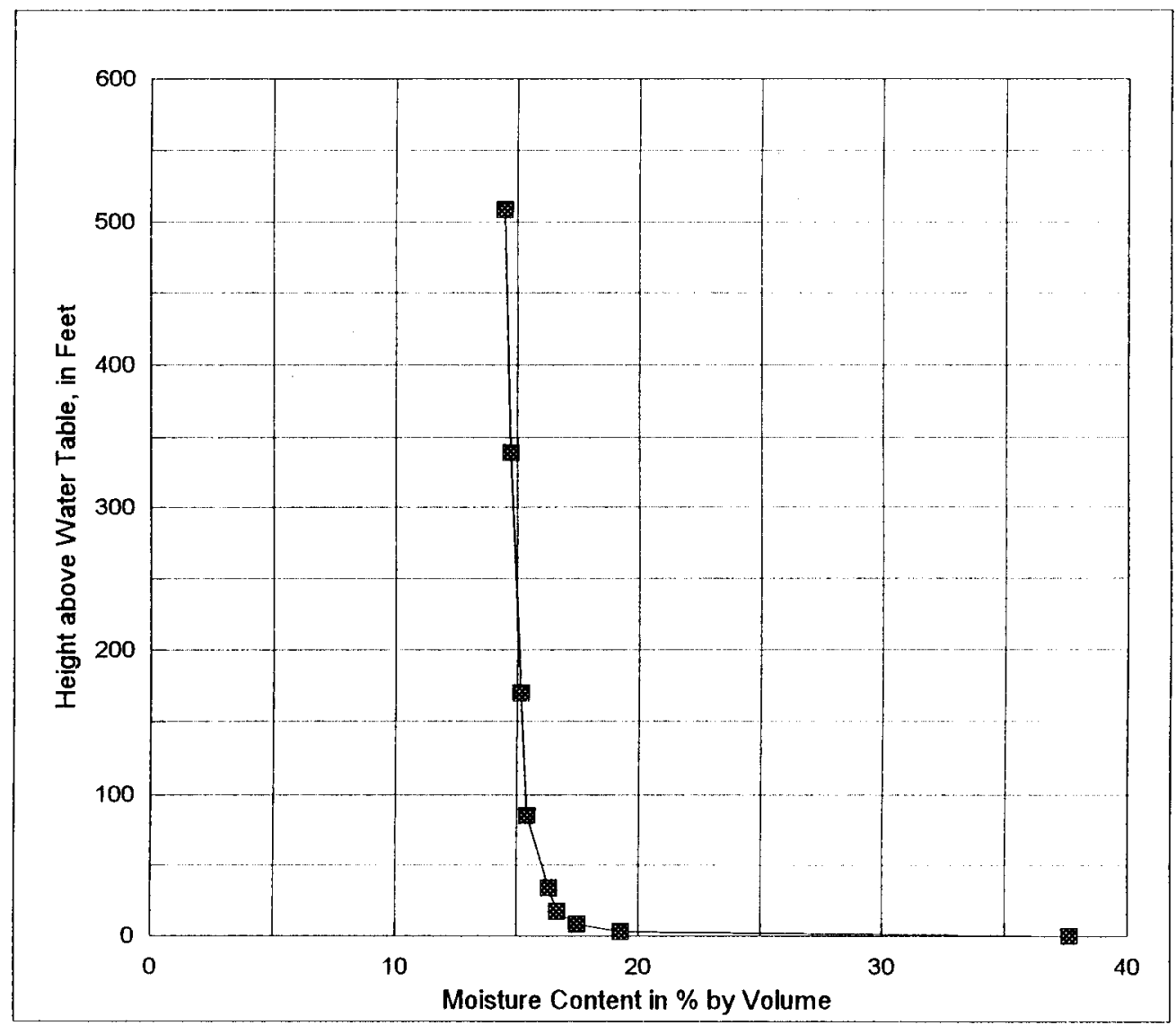

Wilting Point:

14.5

Field Capacity:

17.4 


\section{Appendix B}

Soil Boring Logs 
SOIL BORINGLOG

PROJECT NAME: TTR Septic Waste System

BORING NUMBER: LF4-DBOX-SB

PROJECT NUMBER: 772848.05020200

DATE HOLE STARTED: $12 / 12 / 97$

HOLE SURFACE ELEVATION (feet): 5504.00

DATE HOLE COMPLETED: $12 / 12 / 97$

TOTAL DEPTH OF HOLE (feet): 22.50

ENVIRONMENTAL CONTRACTOR: IT Corporation

EASTING: 474084.90

NORTHING: 1105170.00

GEOLOGIST: RD ATKINSON

Appendix $B$

Revision: 0

DRILLING METHOD: HOLLOW STEM AUGER

QA CHECK: G EVENSON

Date: $06 / 24 / 98$

DRILLING CONTRACTOR: Stewart Brothers

COMMENTS: Boring destroyed with bentonite grout.

ELEVATION DATUM: Mean Sea Level

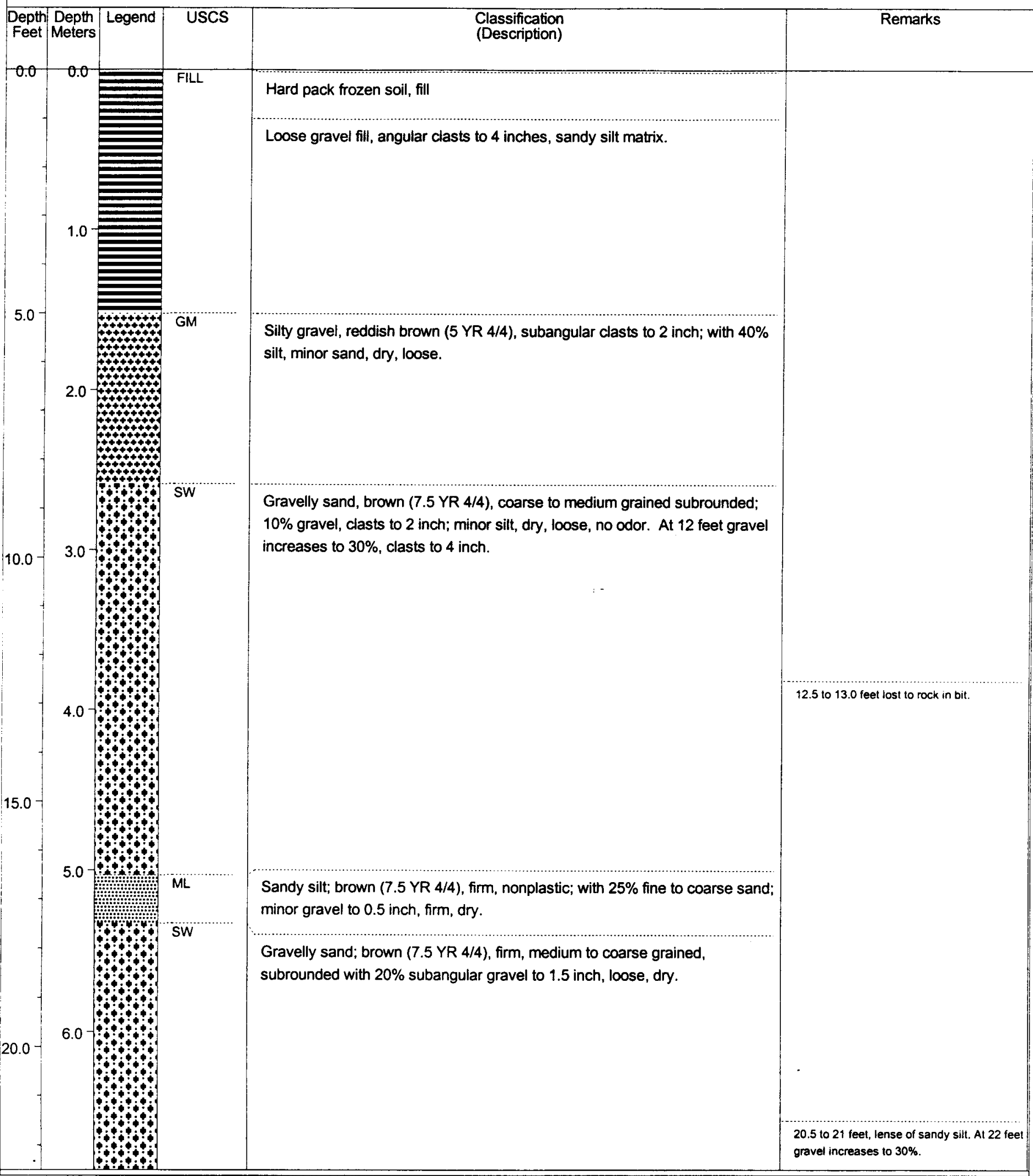




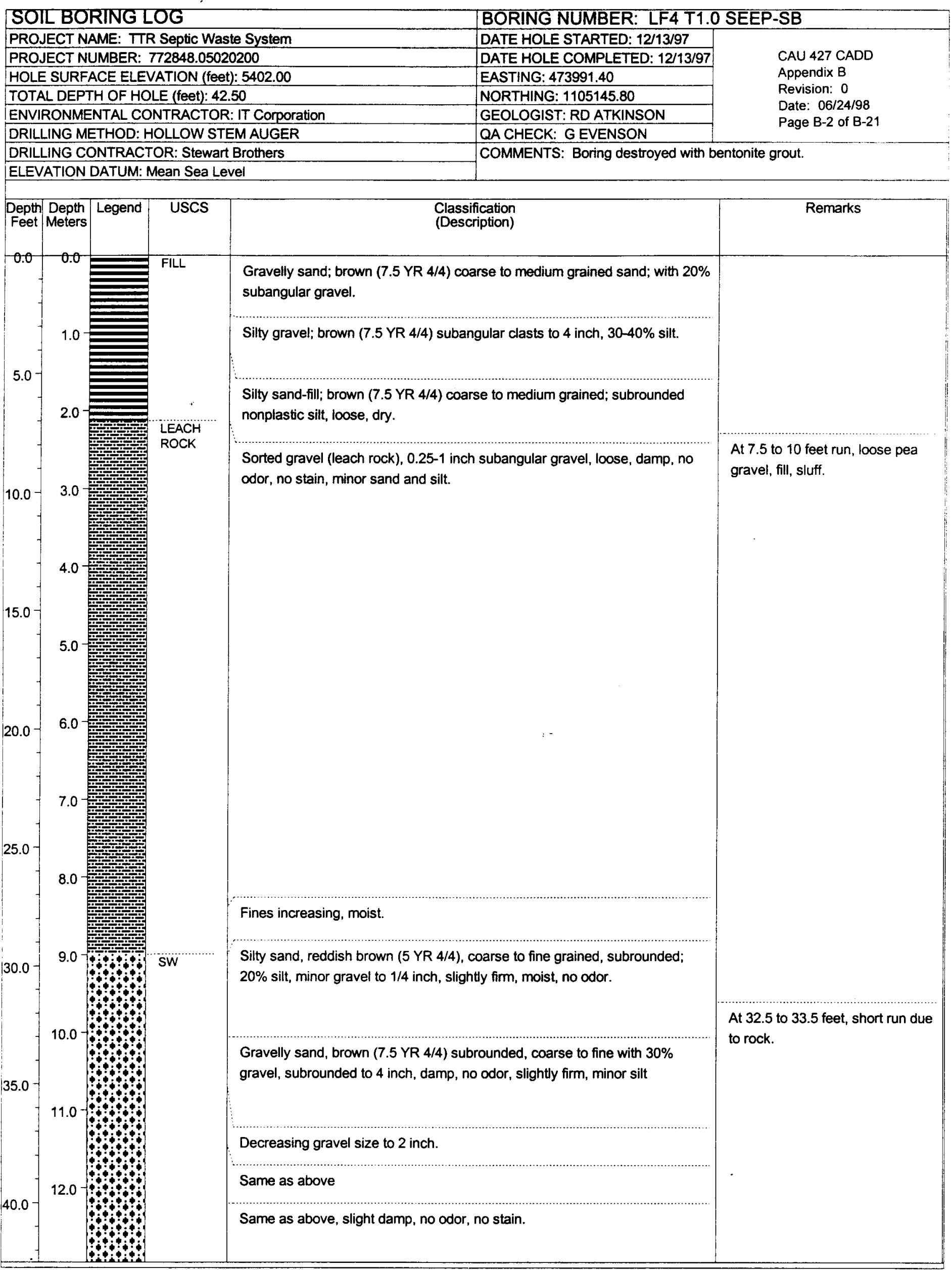


SOIL BORING LOG

PROJECT NAME: TTR Septic Waste System

PROJECT NUMBER: 772848.05020200

HOLE SURFACE ELEVATION (feet): 5402.00

TOTAL DEPTH OF HOLE (feet): 30.00

ENVIRONMENTAL CONTRACTOR: IT Corporation

DRILLING METHOD: HOLLOW STEM AUGER

DRILLING CONTRACTOR: Stewart Brothers

ELEVATION DATUM: Mean Sea Level
BORING NUMBER: LF4-TI-20.0 SEEP-SB

DATE HOLE STARTED: 12/14/97

DATE HOLE COMPLETED: 12/14/97

EASTING: 473991.00

NORTHING: 1105146.45

GEOLOGIST: RD ATKINSON

QA CHECK: G EVENSON

CAU 427 CADD

Appendix B

Revision: 0

Date: $06 / 24 / 98$

Page B-3 of B-21

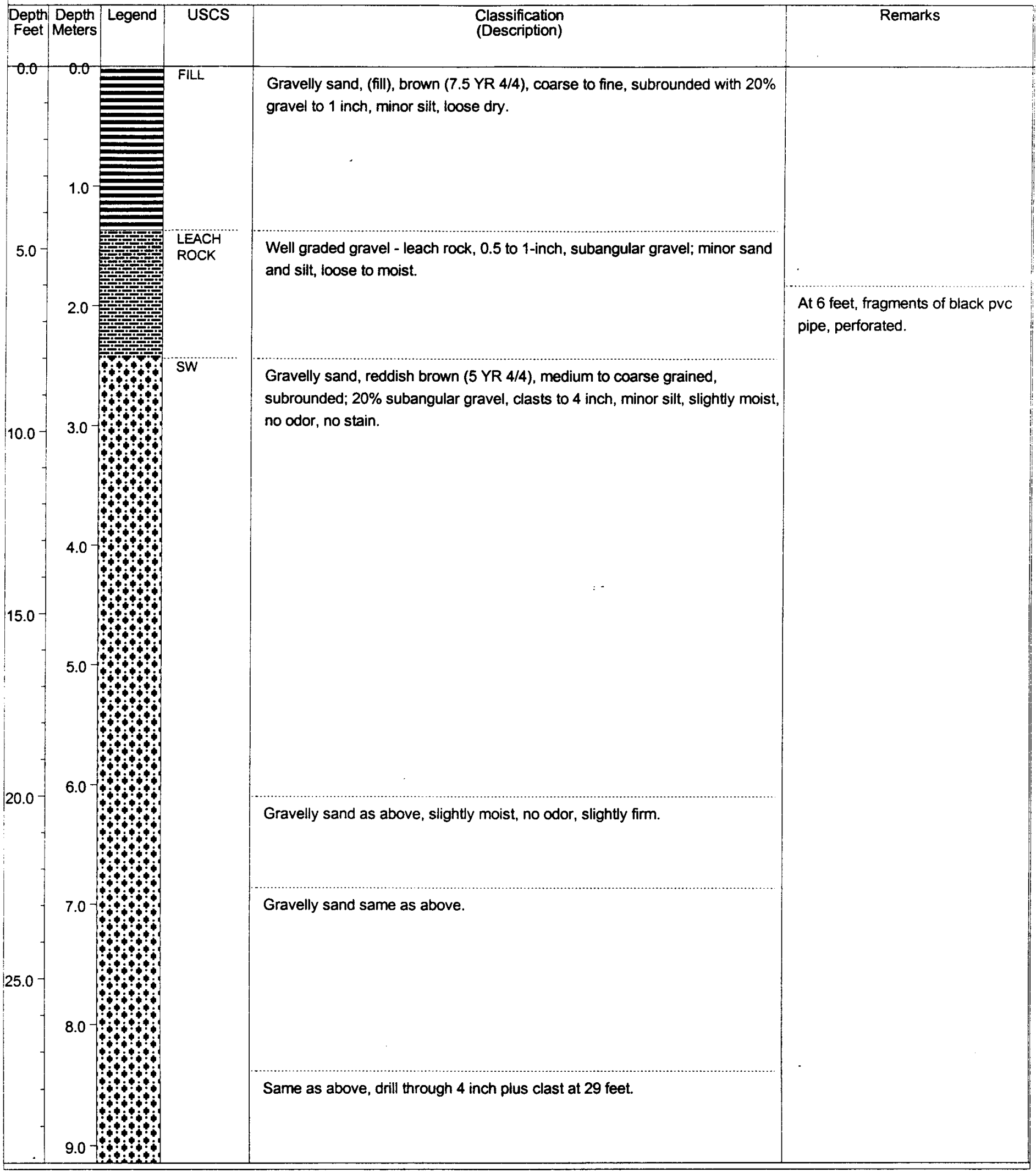


SOIL BORING LOG

PROJECT NAME: TTR Septic Waste System

PROJECT NUMBER: 772848.05020200

HOLE SURFACE ELEVATION (feet): 5402.00

TOTAL DEPTH OF HOLE (feet): 37.50

ENVIRONMENTAL CONTRACTOR: IT Corporation

DRILLING METHOD: HOLLOW STEM AUGER

DRILLING CONTRACTOR: Stewart Brothers

ELEVATION DATUM: Mean Sea Level
BORING NUMBER: LF4-TI-20.0 SEEP(D/G)-SB DATE HOLE STARTED: 12/14/97 DATE HOLE COMPLETED: $12 / 14 / 97$

EASTING: 473982.80

NORTHING: 1105164.00

GEOLOGIST: RD ATKINSON

QA CHECK: G EVENSON

COMMENTS: Boring destroyed with bentonite grout.

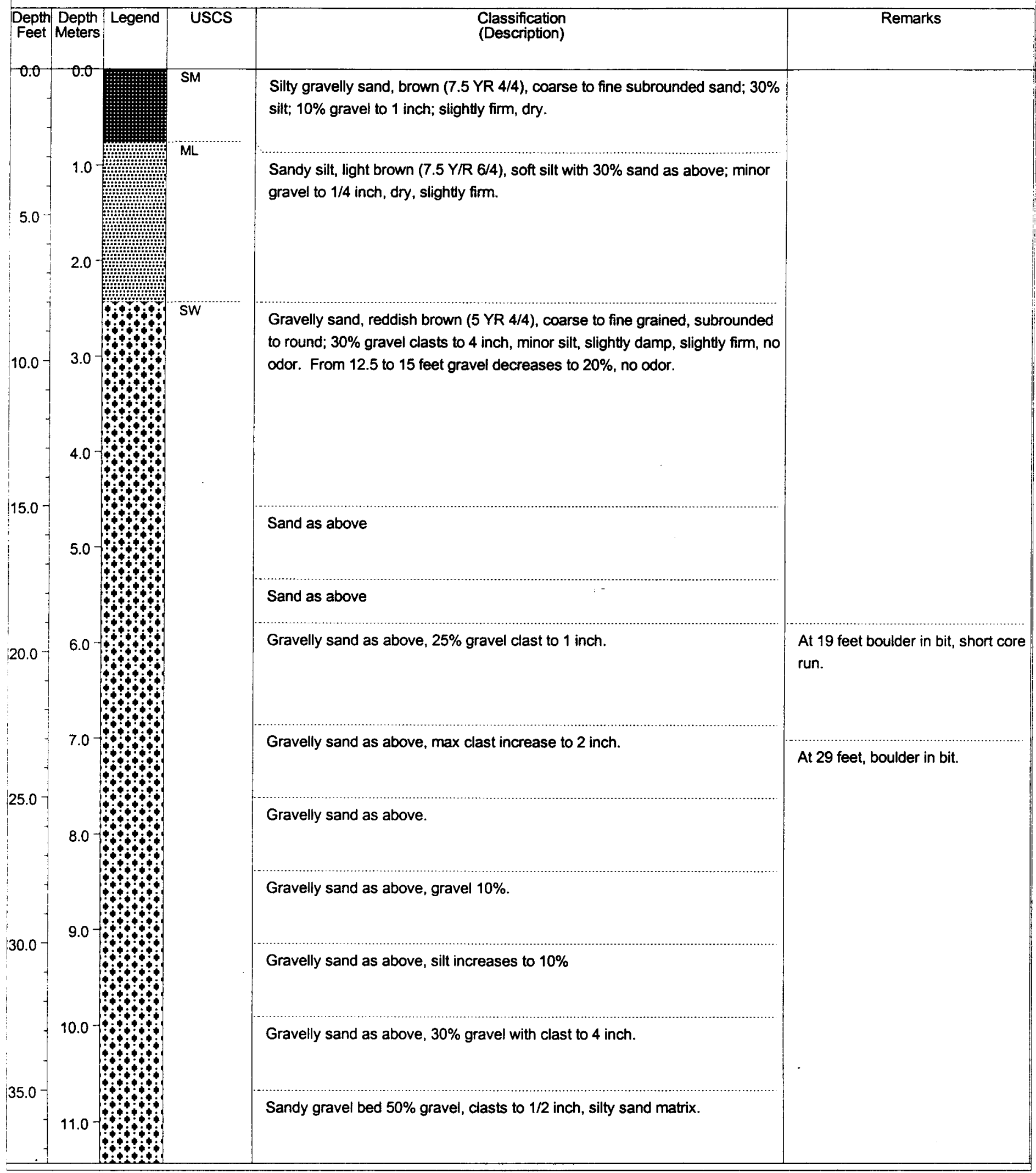


BORING NUMBER: LF4-TI-40.0 SEEP U/G-SB

PROJECT NAME: TTR Septic Waste System DATE HOLE STARTED: 12/14/97

PROJECT NUMBER: 772848.05020200

DATE HOLE COMPLETED: $12 / 15 / 97$

HOLE SURFACE ELEVATION (feet): 5402.00

EASTING: 473989.10

TOTAL DEPTH OF HOLE (feet): 42.50

NORTHING: 1105185.60

ENVIRONMENTAL CONTRACTOR: IT Corporation

GEOLOGIST: RD ATKINSON

CAU 427 CADD

Appendix B

Revision: 0

DRILLING METHOD: HOLLOW STEM AUGER

QA CHECK: G EVENSON

DRILLING CONTRACTOR: Stewart Brothers

COMMENTS: Boring destroyed with bentonite grout.

ELEVATION DATUM: Mean Sea Level

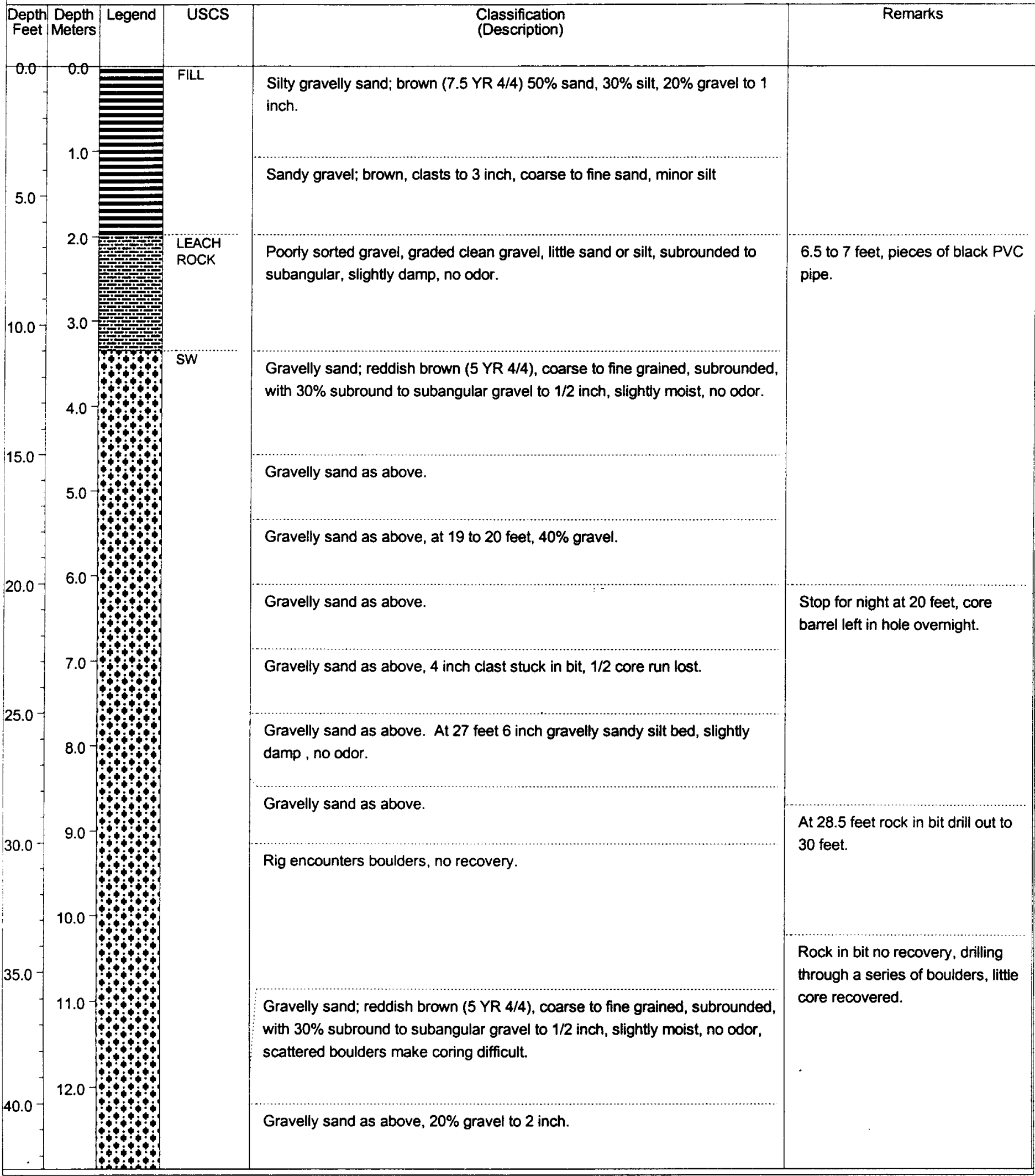




\section{SOIL BORING LOG}

PROJECT NAME: TTR Septic Waste System

PROJECT NUMBER: 772848.05020200

HOLE SURFACE ELEVATION (feet): 5402.00

TOTAL DEPTH OF HOLE (feet): 15.00

ENVIRONMENTAL CONTRACTOR: IT Corporation

DRILLING METHOD: HOLLOW STEM AUGER

DRILLING CONTRACTOR: Stewart Brothers

ELEVATION DATUM: Mean Sea Level
BORING NUMBER: 40.0 SEEP-29.0 U/G-SB

DATE HOLE STARTED: $12 / 15 / 97$

DATE HOLE COMPLETED: 12/15/97

EASTING: 474015.10

NORTHING: 1105186.80

GEOLOGIST: RD ATKINSON

QA CHECK: G EVENSON

COMMENTS: Boring destroyed with bentonite grout
CAU 427 CADD

Appendix B

Revision: 0

Date: $06 / 24 / 98$

Page B-6 of B-21

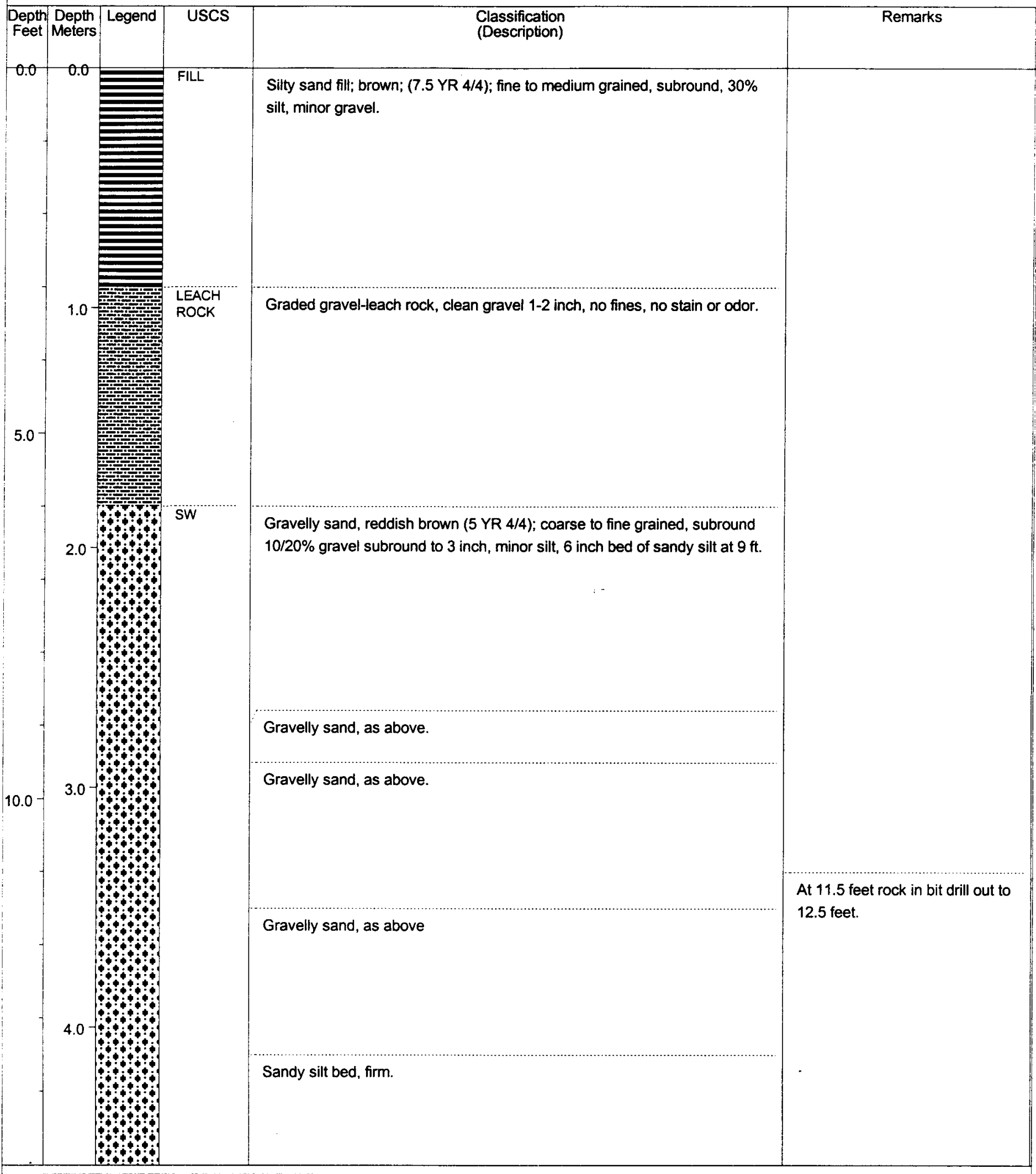


SOIL BORING LOG

PROJECT NAME: TTR Septic Waste System

PROJECT NUMBER: 772848.05020200

HOLE SURFACE ELEVATION (feet): 5404.00

TOTAL DEPTH OF HOLE (feet): 16.50

ENVIRONMENTAL CONTRACTOR: IT Corporation

DRILLING METHOD: HOLLOW STEM AUGER

DRILLING CONTRACTOR: Stewart Brothers

ELEVATION DATUM: Mean Sea Level
BORING NUMBER: 20.0 SEEP-29.0 U/G-SB DATE HOLE STARTED: $12 / 15 / 97$ DATE HOLE COMPLETED: 12/15/97

EASTING: 474016.30

NORTHING: 1105166.00

GEOLOGIST: RD ATKINSON

CAU 427 CADD

Appendix B

Revision: 0

Date: $06 / 24 / 98$

QA CHECK: G EVENSON

Page B-7 of B-21

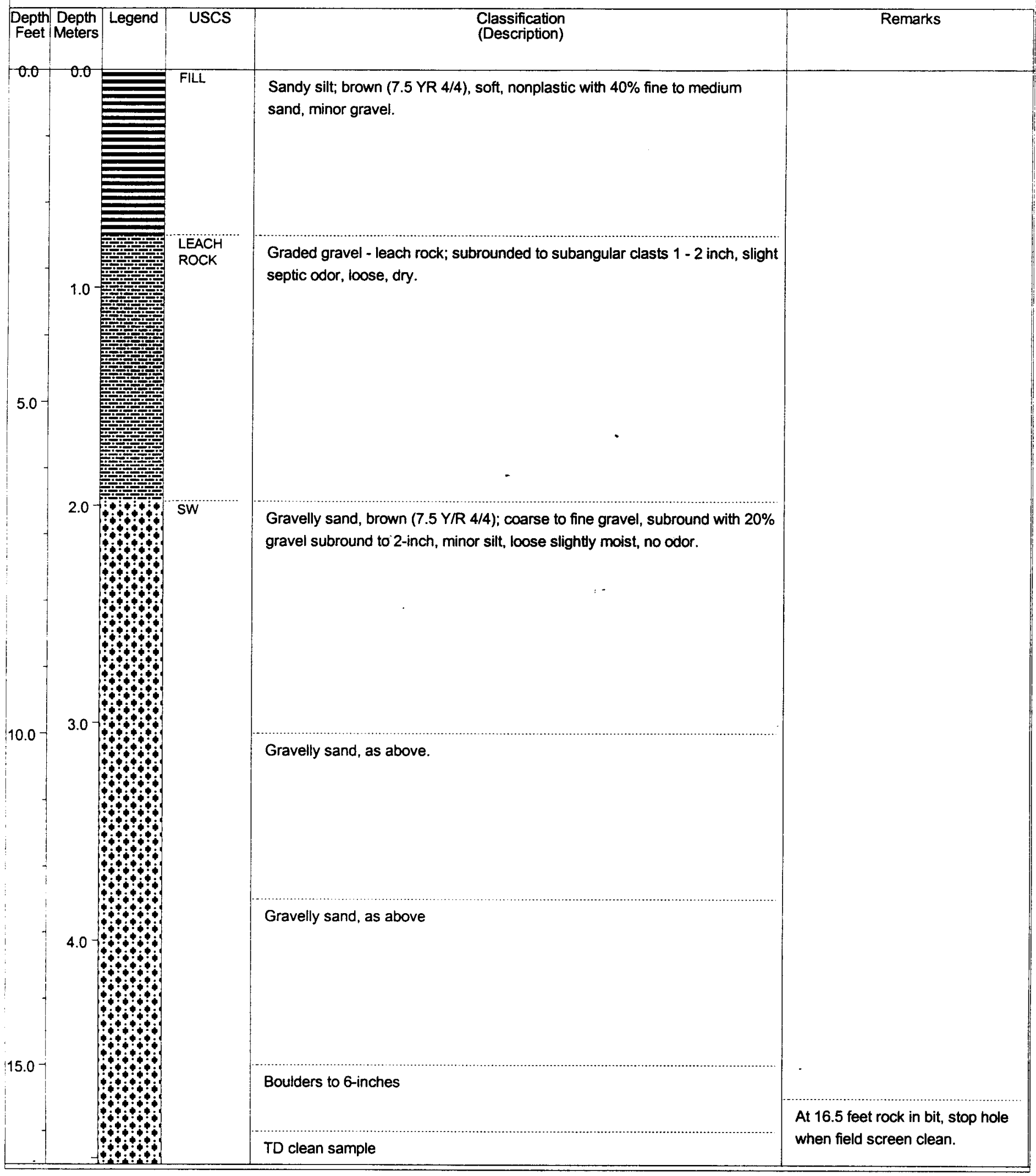


SOIL BORING LOG

PROJECT NAME: TTR Septic Waste System

PROJECT NUMBER: 772848.05020200

HOLE SURFACE ELEVATION (feet): 5402.00

TOTAL DEPTH OF HOLE (feet): 40.00

ENVIRONMENTAL CONTRACTOR: IT Corporation

DRILLING METHOD: HOLLOW STEM AUGER

DRILLING CONTRACTOR: Stewart Brothers

ELEVATION DATUM: Mean Sea Level
BORING NUMBER: LF4-T1-20.0 SEEP-CENTER-SB

DATE HOLE STARTED: $12 / 17 / 97$

DATE HOLE COMPLETED: $12 / 17 / 97$

EASTING: 473987.30

NORTHING: 1105164.30

GEOLOGIST: RD ATKINSON

QA CHECK: G EVENSON

COMMENTS: Boring destroyed with bentonite grout.
CAU 427 CADD

Appendix $B$

Revision: 0

Date: $06 / 24 / 98$

Page B-8 of B-21

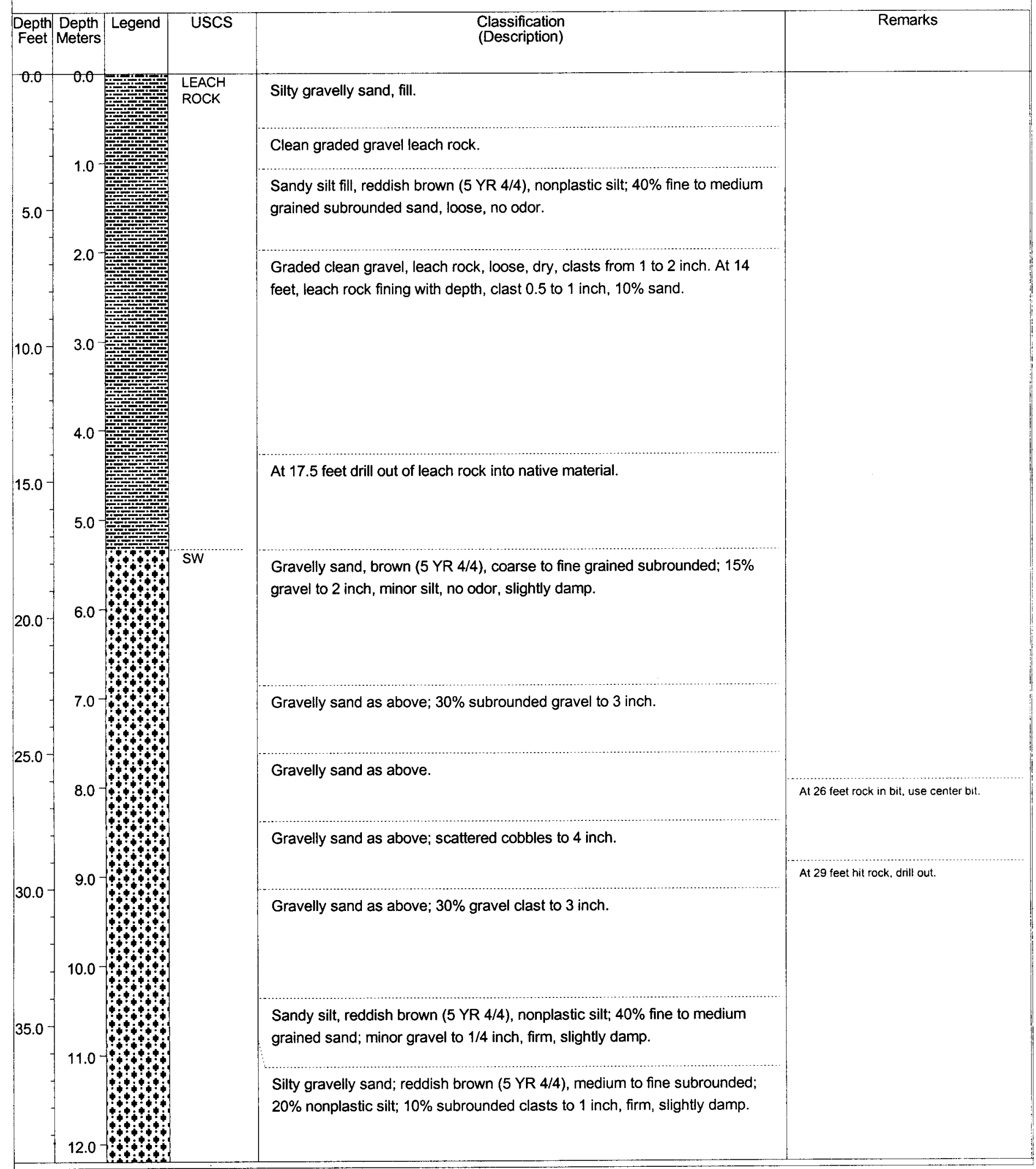




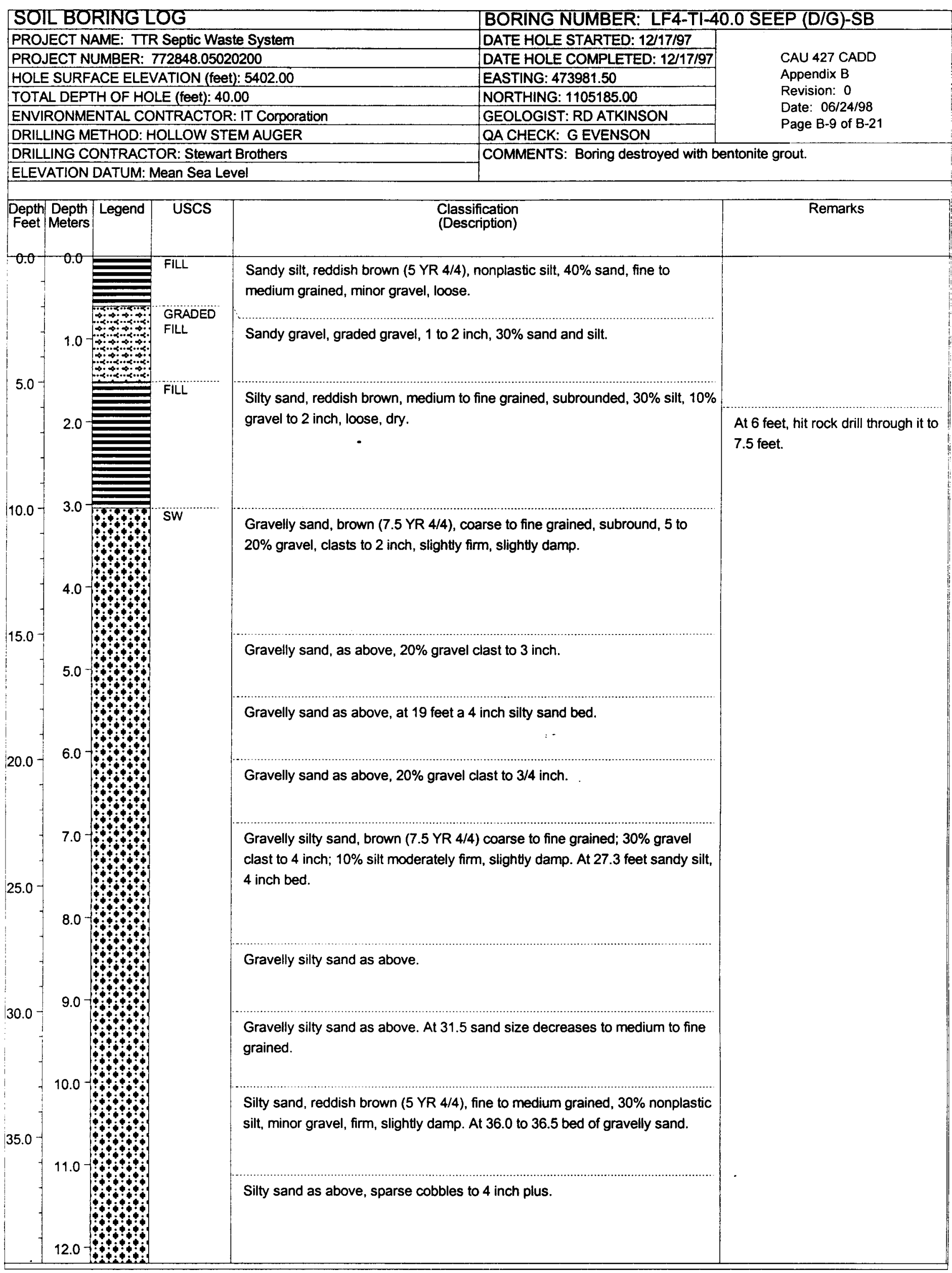


\begin{tabular}{|l}
\hline PROJECT NAME: TTR Septic Waste System \\
\hline PROJECT NUMBER: 772848.05020200 \\
\hline
\end{tabular}

HOLE SURFACE ELEVATION (feet): 5402.00

TOTAL DEPTH OF HOLE (feet): 44.00

ENVIRONMENTAL CONTRACTOR: IT Corporation

DRILLING METHOD: HOLLOW STEM AUGER

DRILLING CONTRACTOR: Stewart Brothers

ELEVATION DATUM: Mean Sea Level
DATE HOLE STARTED: 12/18/97

DATE HOLE COMPLETED: $12 / 18 / 97$

EASTING: 473986.70

NORTHING: 1105184.70

GEOLOGIST: RD ATKINSON

QA CHECK: GEVENSON

COMMENTS: Boring destroyed with bentonite grout.
CAU 427 CADD

Appendix B

Revision: 0

Date: $06 / 24 / 98$

Page B-10 of B-21

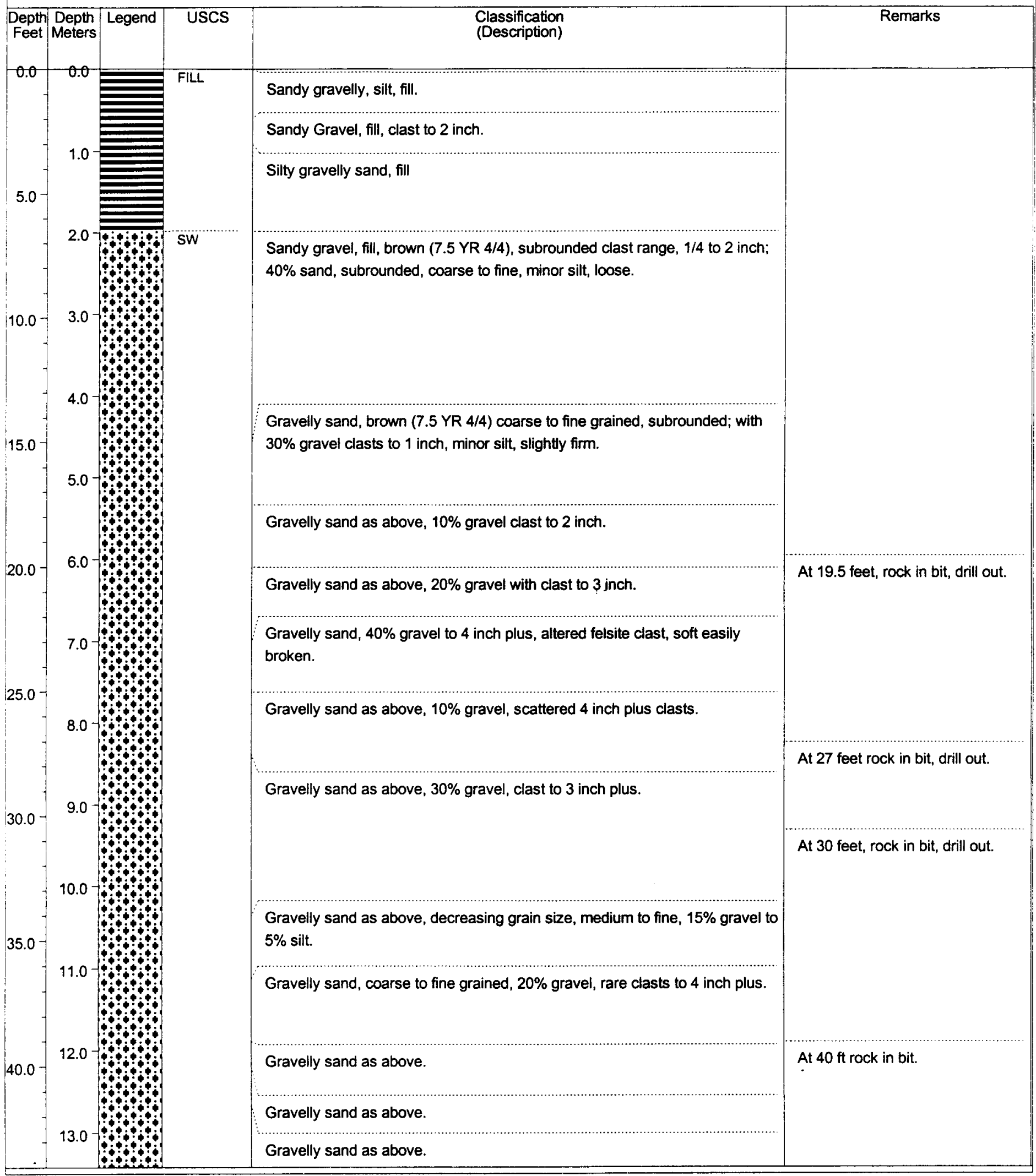




\section{SOIL BORINGLOG}

PROJECT NAME: TTR Septic Waste System

PROJECT NUMBER: 772848.05020200

HOLE SURFACE ELEVATION (feet): 5402.00

TOTAL DEPTH OF HOLE (feet): 42.50

ENVIRONMENTAL CONTRACTOR: IT Corporation

DRILLING METHOD: HOLLOW STEM AUGER

DRILLING CONTRACTOR: Stewart Brothers

ELEVATION DATUM: Mean Sea Level
BORING NUMBER: LF4-T1-1.0 SEEP (D/G)-SB DATE HOLE STARTED: 12/18/97

DATE HOLE COMPLETED: 12/19/97

EASTING: 473988.30

NORTHING: 1105195.30

GEOLOGIST: RD ATKINSON

QA CHECK: GEVENSON

COMMENTS: Boring destroyed with bentonite grout.

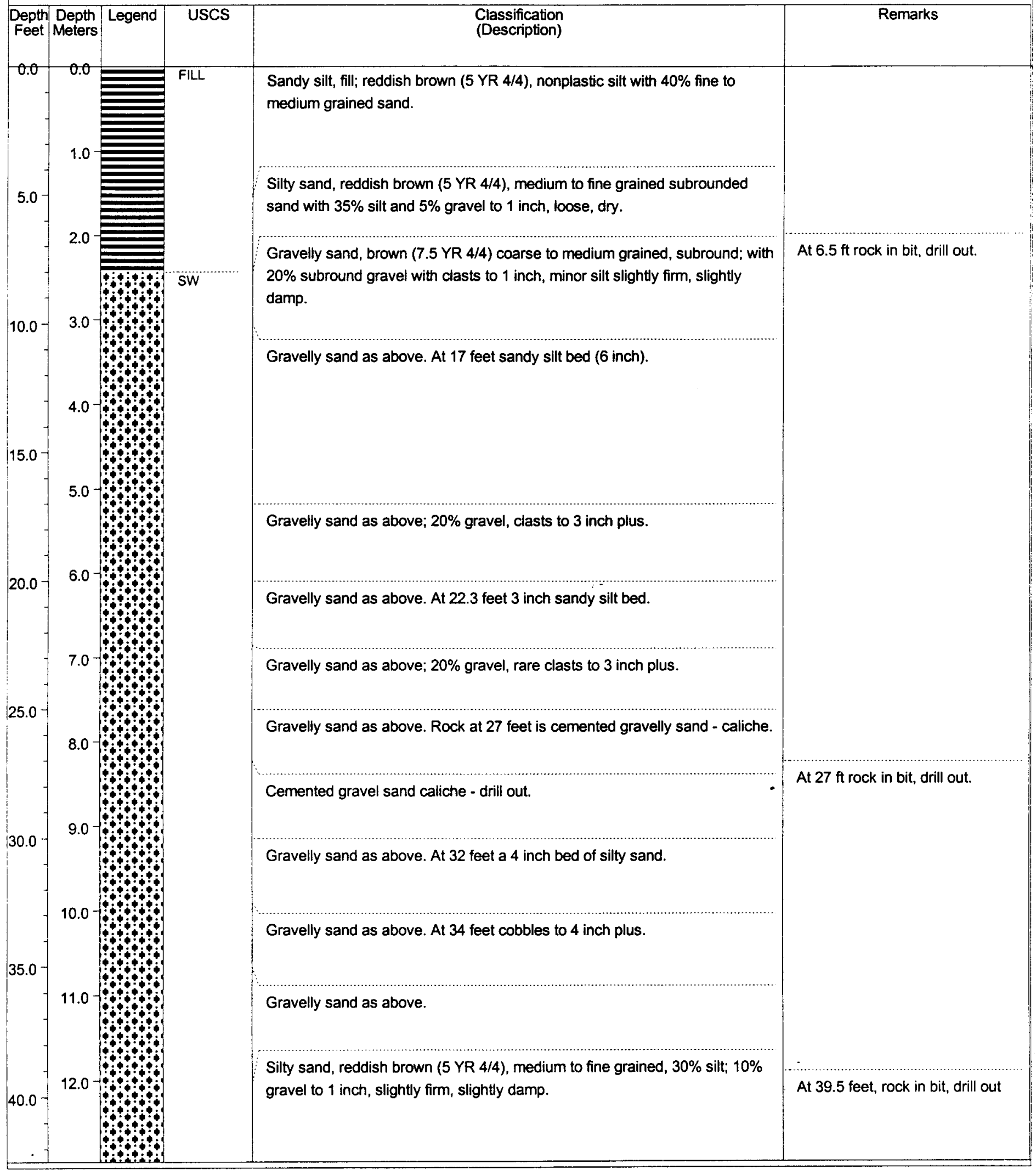


TOTAL DEPTH OF HOLE (feet): 22.50 NORTHING: 1105195.00

ENVIRONMENTAL CONTRACTOR: IT Corporation

GEOLOGIST: JM MOORE

Date: $06 / 24 / 98$

DRILLING METHOD: HOLLOW STEM AUGER

QA CHECK: GEVENSON

DRILLING CONTRACTOR: Stewart Brothers

COMMENTS: Boring destroyed with bentonite grout

\section{ELEVATION DATUM: Mean Sea Level}

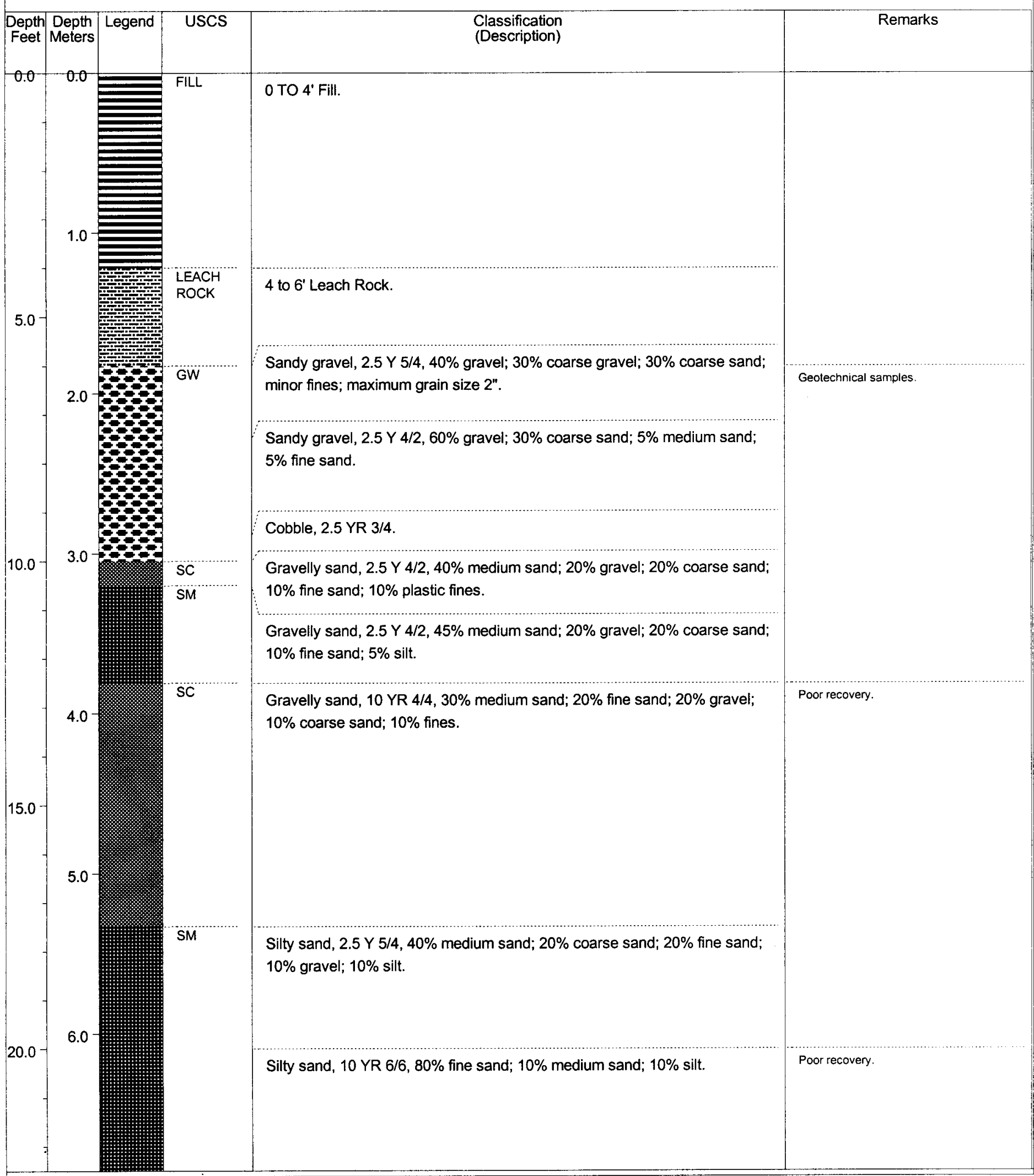


HOLE SURFACE ELEVATION (feet): 5406.00

TOTAL DEPTH OF HOLE (feet): 14.50

EASTING: 474126.40

ENVIRONMENTAL CONTRACTOR: IT Corporation

NORTHING: 1105193.50

DRILLING METHOD: HOLLOW STEM AUGER

GEOLOGIST: JM MOORE

QA CHECK: G EVENSON

COMMENTS: Boring destroyed with bentonite grout.
CAU 427 CADD

Appendix B

Revision: 0

Date: $06 / 24 / 98$

Page B-13 of B-21

ELEVATION DATUM: Mean Sea Level

\begin{tabular}{|c|c|c|c|c|c|}
\hline \begin{tabular}{|l|} 
Depth \\
Feet
\end{tabular} & \begin{tabular}{|l|} 
Depth \\
Meters
\end{tabular} & Legend & USCS & $\begin{array}{l}\text { Classification } \\
\text { (Description) }\end{array}$ & Remarks \\
\hline 0.0 & 0.0 & & SM & Drill out & \\
\hline .0 & & & & $\begin{array}{l}\text { Silty sand ( } 10 \text { YR } 6 / 3 \text { ), about } 30 \% \text { medium sand; about } 20 \% \text { fine sand; about } \\
20 \% \text { coarse sand; about } 20 \% \text { gravel; about } 10 \% \text { silt, maximum grain size } 2 \\
\text { inch. }\end{array}$ & \\
\hline \multirow{4}{*}{10.0} & & & & $\begin{array}{l}\text { Silty sand ( } 10 \text { YR } 5 / 3 \text { ), about } 30 \% \text { coarse sand; } 20 \% \text { medium sand; } 20 \% \\
\text { coarse gravel; } 10 \% \text { gravel; } 10 \% \text { fine sand, } 10 \% \text { silt. }\end{array}$ & \multirow{3}{*}{ ' } \\
\hline & & & GW & $\begin{array}{l}\text { Sandy gravel ( } 10 \text { YR } 5 / 4 \text { ), about } 30 \% \text { coarse sand; about } 30 \% \text { gravel; about } \\
30 \% \text { coarse gravel; about } 10 \% \text { silt. }\end{array}$ & \\
\hline & \multirow{2}{*}{$4.0-$} & \multirow[t]{2}{*}{$\frac{11}{11}$} & \multirow[t]{2}{*}{ SM } & \multirow[t]{2}{*}{$\begin{array}{l}\text { Gravelly sand ( } 2.5 \text { YR } 6 / 3 \text { ), about } 30 \% \text { coarse sand; about } 30 \% \text { gravel; about } \\
20 \% \text { coarse gravel; about } 10 \% \text { fine sand; about } 10 \% \text { silt. }\end{array}$} & \\
\hline & & & & & $\begin{array}{l}\text { Drilling stopped, large volcanic } \\
\text { rock fragment blocking shoe. }\end{array}$ \\
\hline
\end{tabular}


HOLE SURFACE ELEVATION (feet): 5404.00

TOTAL DEPTH OF HOLE (feet): 22.50

ENVIRONMENTAL CONTRACTOR: IT Corporation

DRILLING METHOD: HOLLOW STEM AUGER

DRILLING CONTRACTOR: Stewart Brothers

\section{EASTING: 474089.20}

NORTHING: 1105186.40

GEOLOGIST: JM MOORE

QA CHECK: GEVENSON

COMMENTS: Boring destroyed with bentonite grout.
CAU 427 CADD

Appendix B

Revision: 0

Date: $06 / 24 / 98$

Page B-14 of B-21

ELEVATION DATUM: Mean Sea Level

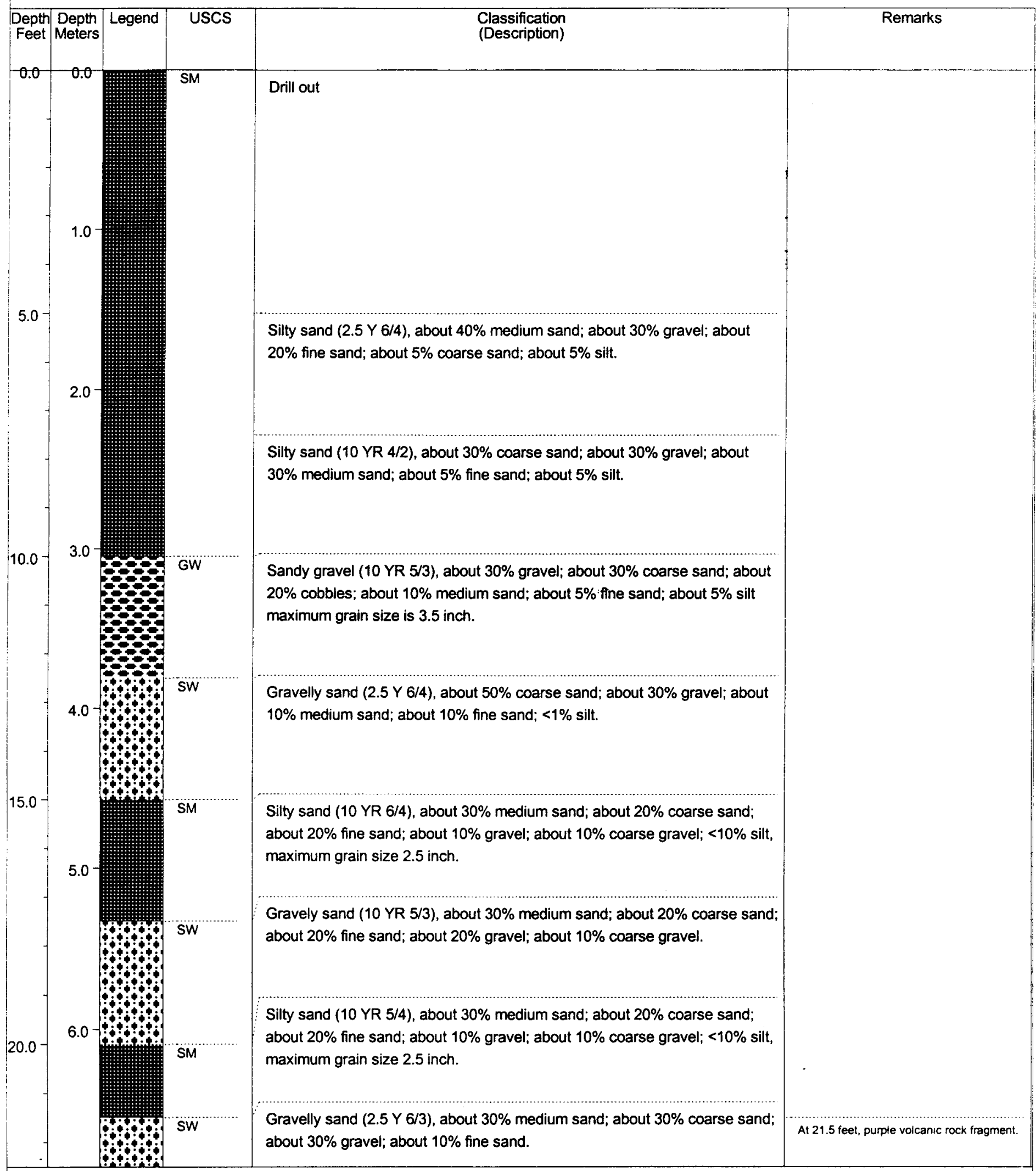


EASTING: 474061.40

TOTAL DEPTH OF HOLE (feet): 22.50

ENVIRONMENTAL CONTRACTOR: IT Corporation

DRILLING METHOD: HOLLOW STEM AUGER

DRILLING CONTRACTOR: Stewart Brothers

NORTHING: 1105187.40

GEOLOGIST: JM MOORE

QA CHECK: GEVENSON

ELEVATION DATUM: Mean Sea Level
CAU 427 CADD

Appendix $B$

Revision: 0

Date: $06 / 24 / 98$

Page B-15 of B-21

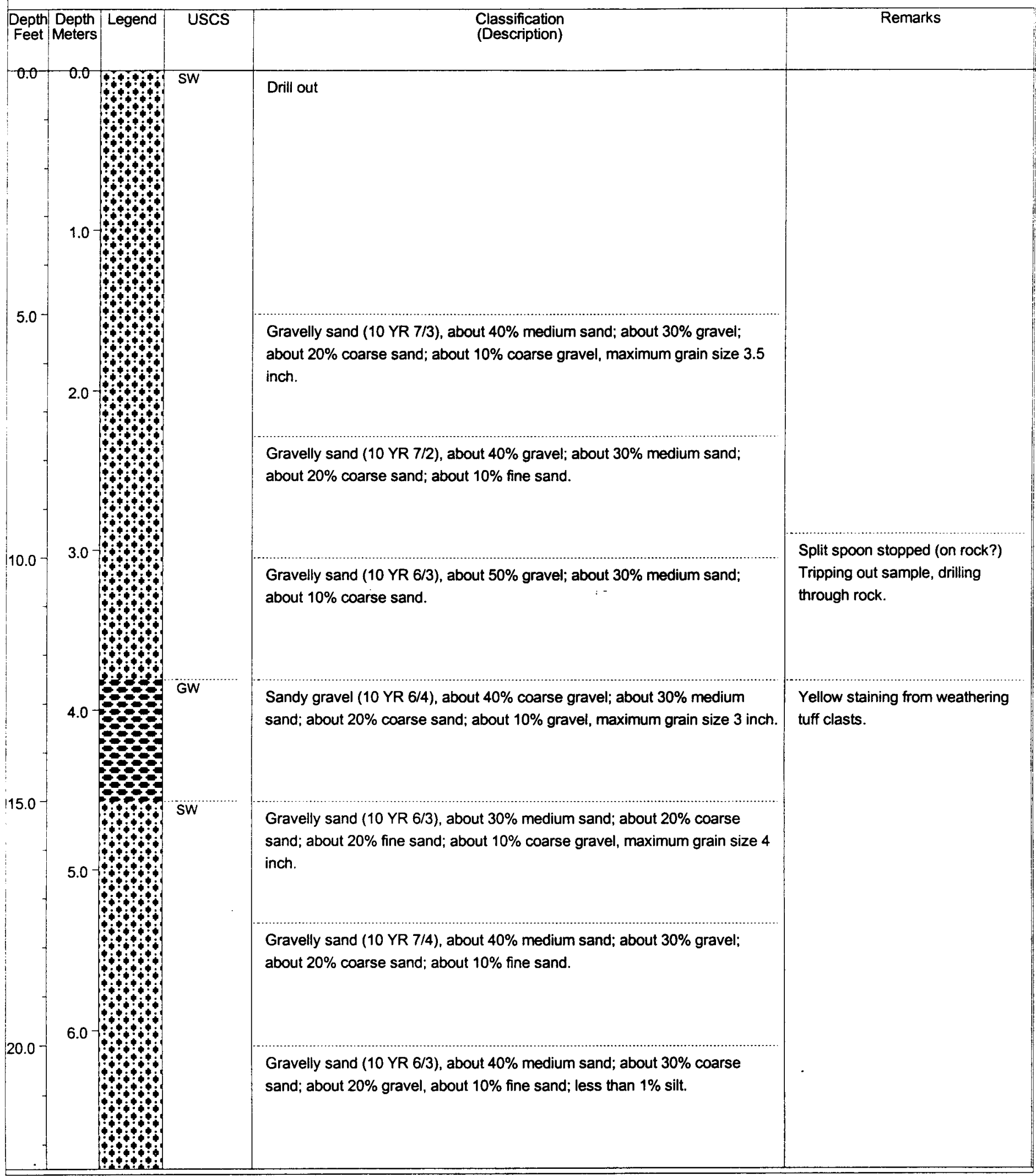


SOIL BORING LOG

BORING NUMBER: LF2 WEST-SB

PROJECT NAME: TTR Septic Waste System

PROJECT NUMBER: 772848.05020200

DATE HOLE STARTED: 12/11/97

HOLE SURFACE ELEVATION (feet): 5404.00

DATE HOLE COMPLETED: 12/11/97

EASTING: 474061.80

TOTAL DEPTH OF HOLE (feet): 22.50

NORTHING: 1105198.20

CAU 427 CADD
Appendix B

ENVIRONMENTAL CONTRACTOR: IT Corporation

GEOLOGIST: JM MOORE

Revision: 0

DRILLING METHOD: HOLLOW STEM AUGER

QA CHECK: G EVENSON

: $06 / 24 / 98$

DRILLING CONTRACTOR: Stewart Brothers

COMMENTS: Boring destroyed with bentonite grout.

ELEVATION DATUM: Mean Sea Level

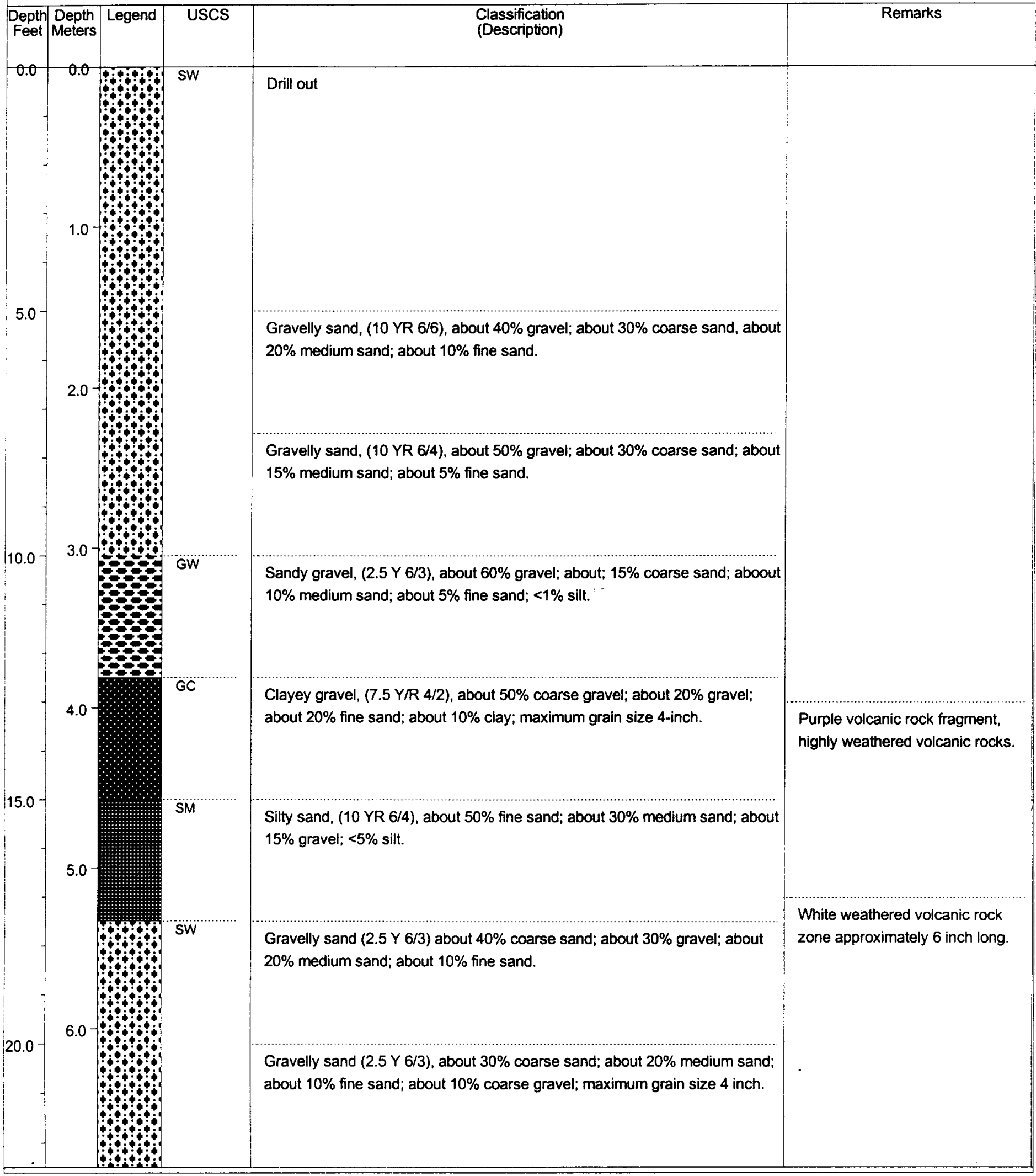


SOIL BORINGLOG

PROJECT NAME: TTR Septic Waste System

PROJECT NUMBER: 772848.05020200

HOLE SURFACE ELEVATION (feet): 5404.00

TOTAL DEPTH OF HOLE (feet): 22.50

ENVIRONMENTAL CONTRACTOR: IT Corporation

DRILLING METHOD: HOLLOW STEM AUGER

DRILLING CONTRACTOR: Stewart Brothers

ELEVATION DATUM: Mean Sea Level
BORING NUMBER: LF2 SW CORNER-SB

DATE HOLE STARTED: 12/11/97

DATE HOLE COMPLETED: $12 / 11 / 97$

EASTING: 474074.10

NORTHING: 1105180.00

GEOLOGIST: JM MOORE

QA CHECK: GEVENSON

COMMENTS: Boring destroyed with bentonite grout.
CAU 427 CADD

Appendix B

Revision: 0

Date: $06 / 24 / 98$

Page B-17 of B-21

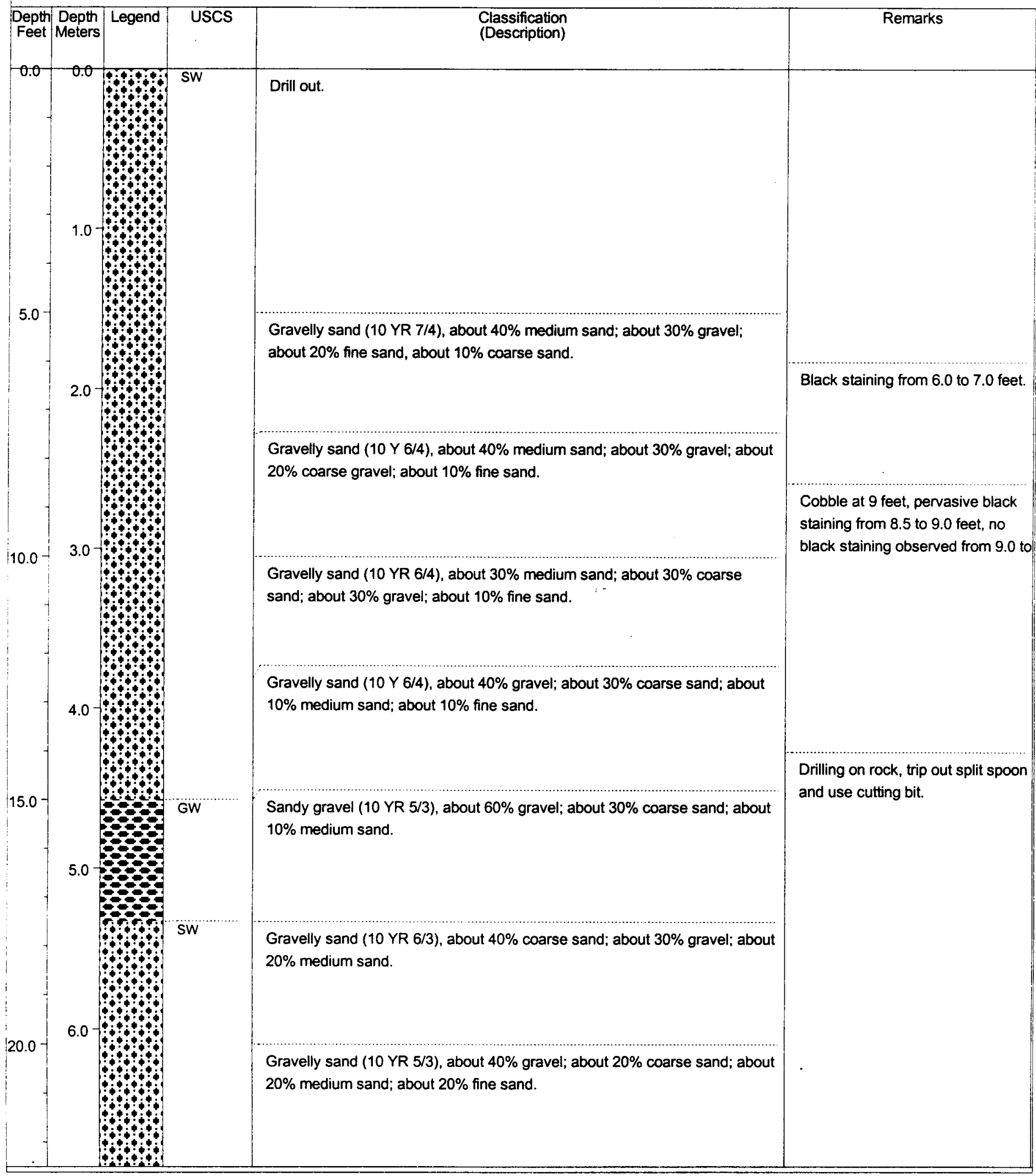




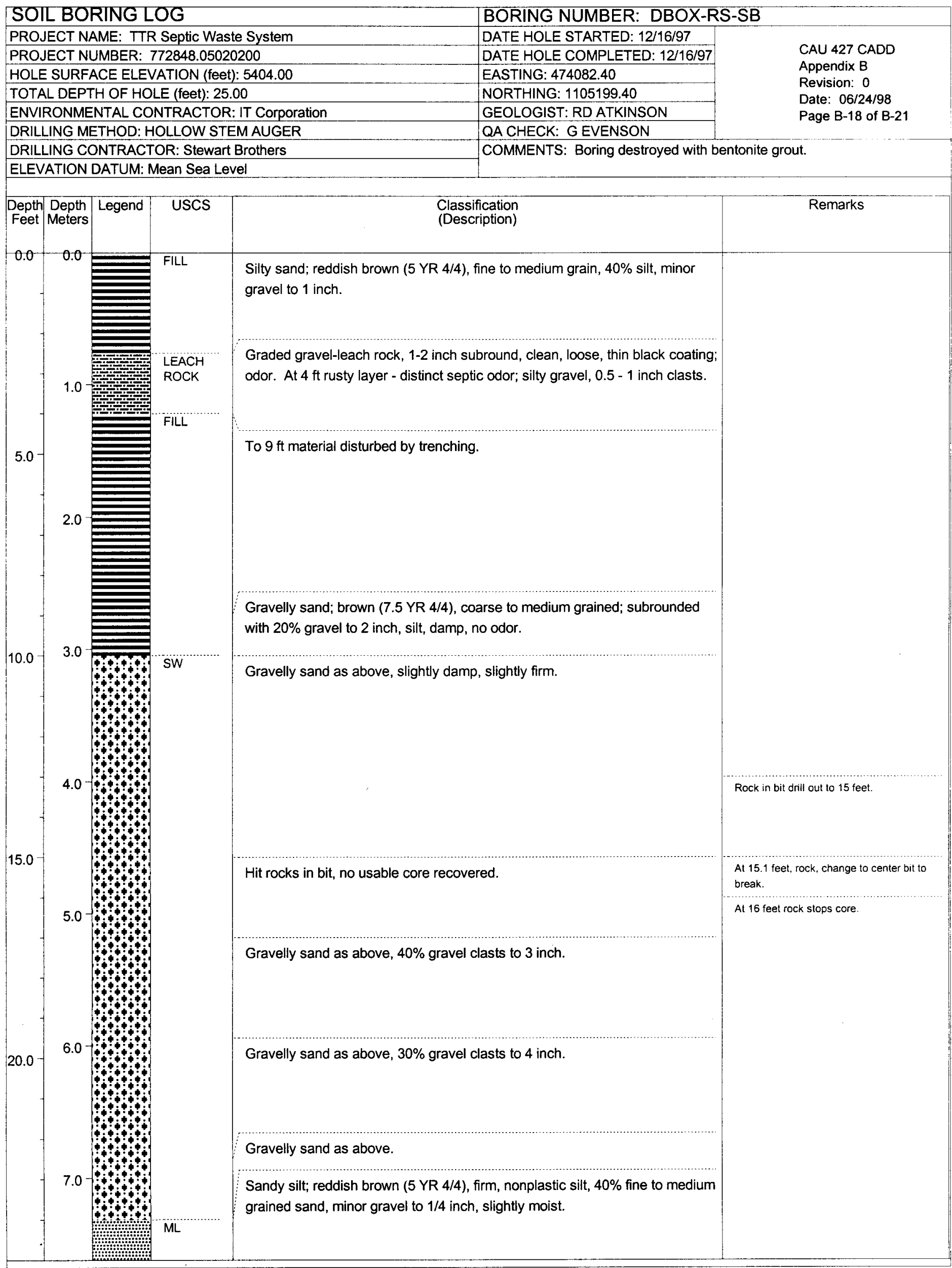




\begin{tabular}{|c|c|c|}
\hline SOIL BORING LOG & \multicolumn{2}{|c|}{ BORING NUMBER: LF2-T1-17.0RS-SB } \\
\hline PROJECT NAME: TTR Septic Waste System & DATE HOLE STARTED: $12 / 16 / 97$ & \multirow{6}{*}{$\begin{array}{l}\text { CAU } 427 \text { CADD } \\
\text { Appendix B } \\
\text { Revision: } 0 \\
\text { Date: } 06 / 24 / 98 \\
\text { Page B-19 of B-21 }\end{array}$} \\
\hline PROJECT NUMBER: 772848.05020200 & DATE HOLE COMPLETED: $12 / 16 / 97$ & \\
\hline HOLE SURFACE ELEVATION (feet): 5404.00 & EASTING: 474090.00 & \\
\hline TOTAL DEPTH OF HOLE (feet): 22.00 & NORTHING: 1105196.00 & \\
\hline ENVIRONMENTAL CONTRACTOR: IT Corporation & GEOLOGIST: RD ATKINSON & \\
\hline DRILLING METHOD: HOLLOW STEM AUGER & QA CHECK: G EVENSON & \\
\hline DRILLING CONTRACTOR: Stewart Brothers & \multirow{2}{*}{\multicolumn{2}{|c|}{ COMMENTS: Boring destroyed with bentonite grout. }} \\
\hline ELEVATION DATUM: Mean Sea Level & & \\
\hline
\end{tabular}

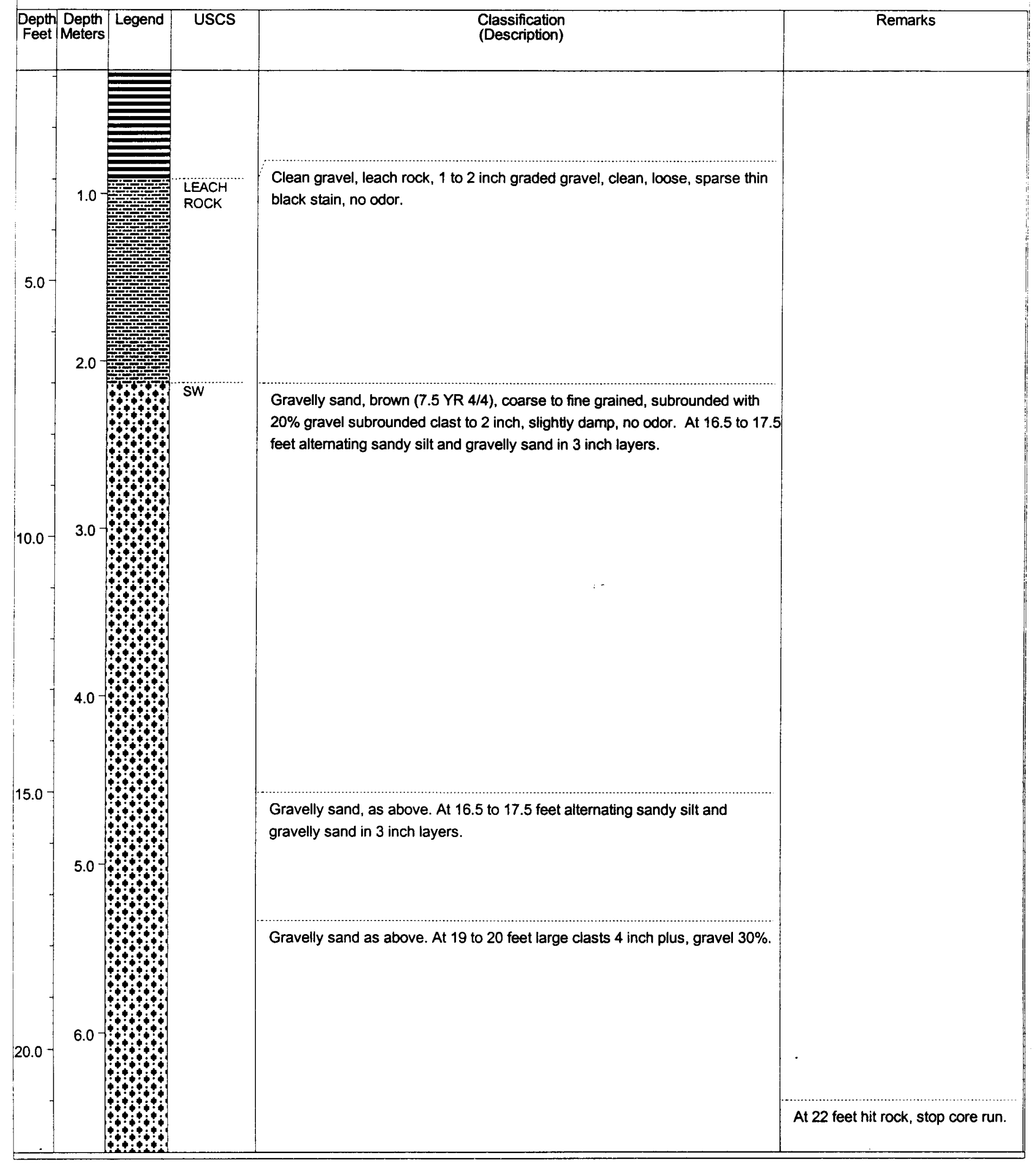


SOIL BORING LOG

PROJECT NAME: TTR Septic Waste System

PROJECT NUMBER: 772848.05020200

HOLE SURFACE ELEVATION (feet): 5404.00

TOTAL DEPTH OF HOLE (feet): 20.00

ENVIRONMENTAL CONTRACTOR: IT Corporation

DRILLING METHOD: HOLLOW STEM AUGER

DRILLING CONTRACTOR: Stewart Brothers

ELEVATION DATUM: Mean Sea Level
BORING NUMBER: LF2-T1-17.0SO-SB

DATE HOLE STARTED: $12 / 09 / 97$

DATE HOLE COMPLETED: $12 / 10 / 97$

EASTING: 474100.70

NORTHING: 1105195.80

GEOLOGIST: JM MOORE

QA CHECK: G EVENSON

COMMENTS: Boring destroyed with bentonite grout
CAU 427 CADD

Appendix B

Revision: 0

Date: $06 / 24 / 98$

Page B-20 of B-21

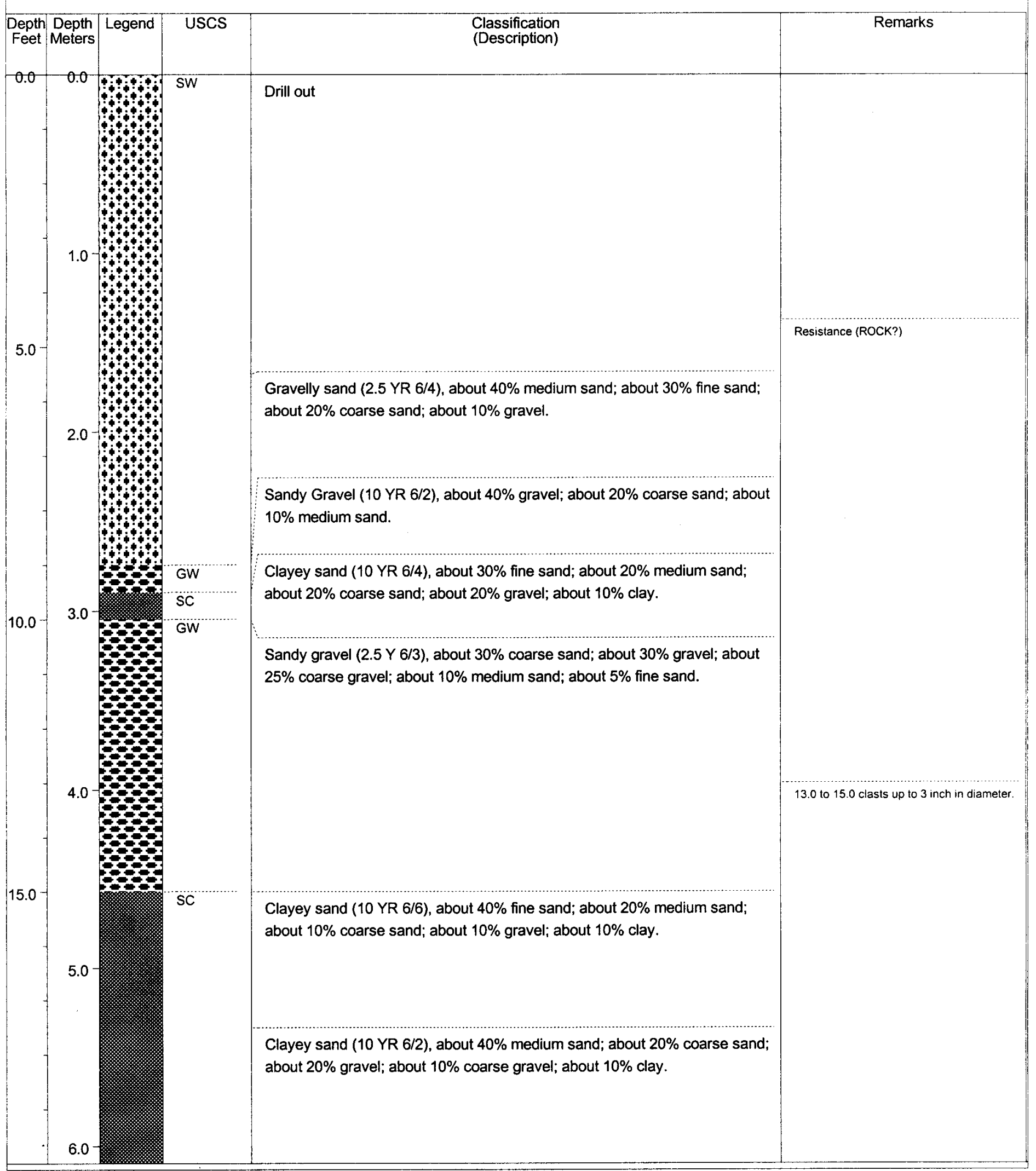


SOIL BORINGLOG

BORING NUMBER: LF4-TI-40.0 SEEP-CENTER (1ST)-SB

PROJECT NAME: TTR Septic Waste System

DATE HOLE STARTED: $12 / 18 / 97$

PROJECT NUMBER: 772848.05020200 DATE HOLE COMPLETED: $12 / 18 / 97$

CAU 427 CADD

HOLE SURFACE ELEVATION (feet): 5402.00

EASTING: 473954.50

TOTAL DEPTH OF HOLE (feet): 15.00

NORTHING: 1105185.90

ENVIRONMENTAL CONTRACTOR: IT Corporation

GEOLOGIST: RD ATKINSON

Appendix B

DRILLING METHOD: HOLLOW STEM AUGER

QA CHECK: GEVENSON

Revision: 0

Date: $06 / 24 / 98$

DRILLING CONTRACTOR: Stewart Brothers

COMMENTS: Boring destroyed with bentonite grout.

ELEVATION DATUM: Mean Sea Level

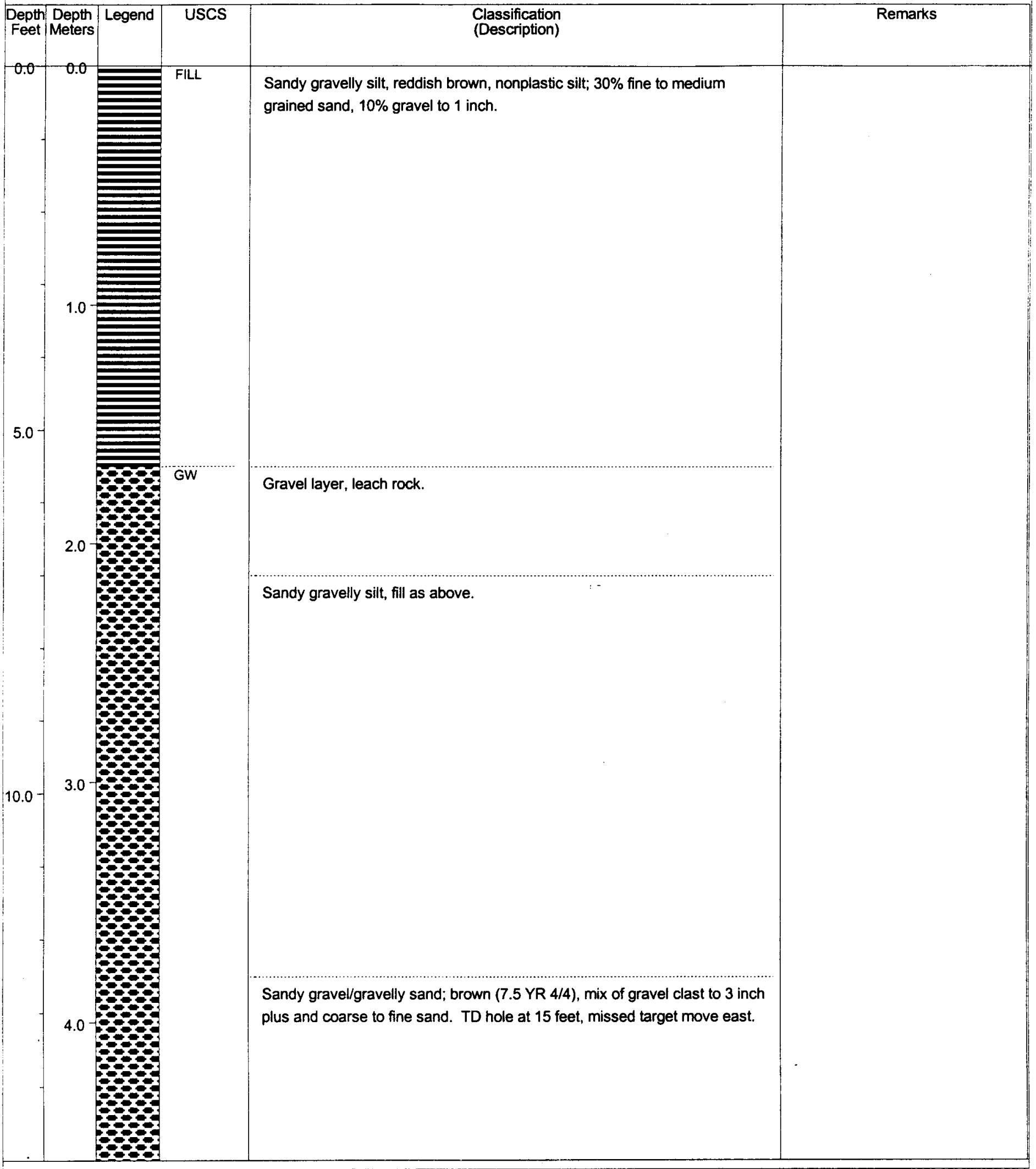


Appendix C

Cost Estimates 


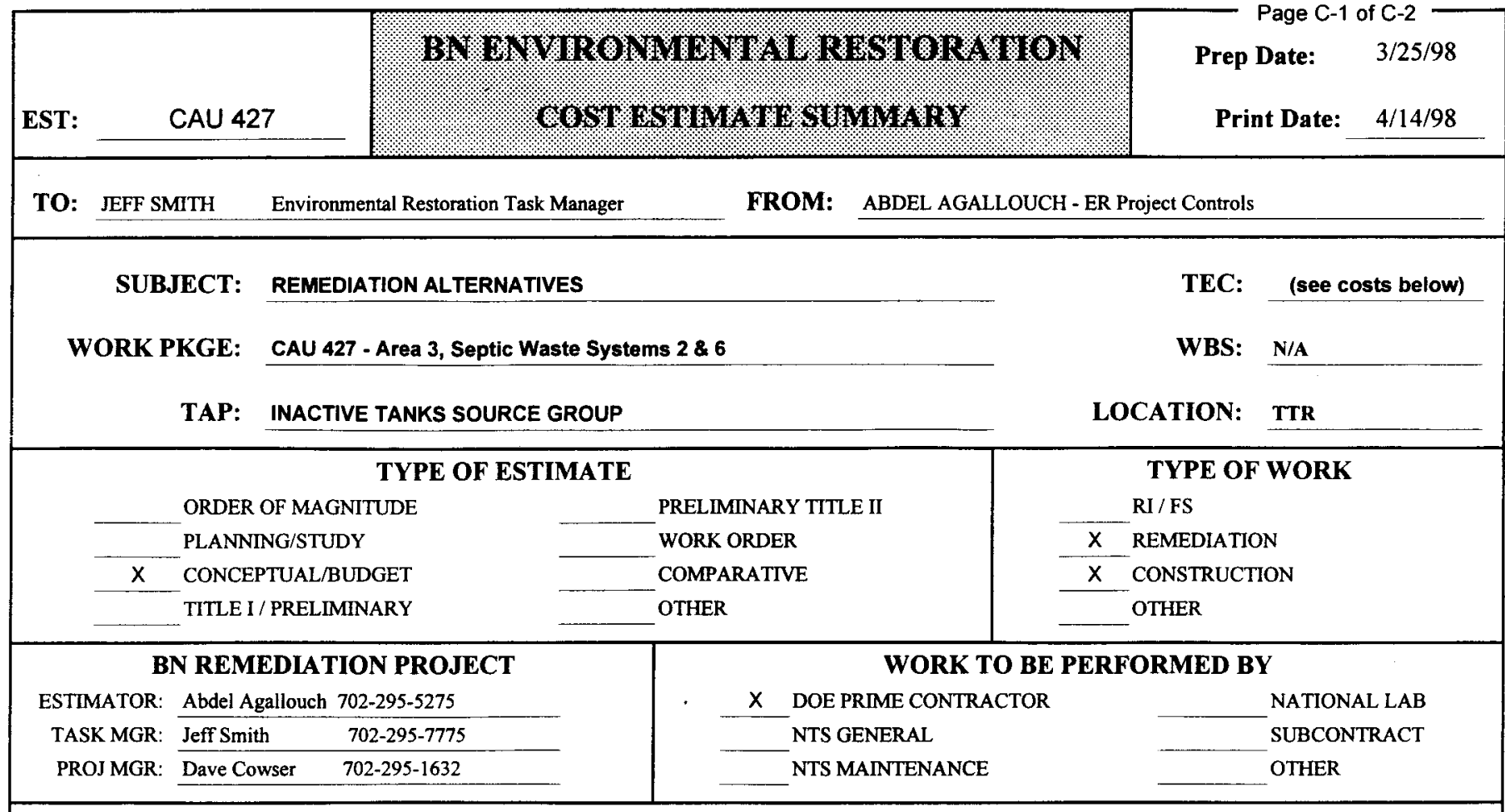

\section{STATEMENTOF WORK:}

This estimate has been prepared at the request of DOE/NV to provide remediation alternative costs for closure of Corrective Action Unit (CAU) 427, an environmental restoration site listed in the Federal Facilities Agreement and Consent Order (FFACO).

SCORE:

Provide site closure using one or more of the following alternatives:

- NO FURTHER ACTION

- ClOSURE OF SEPTIC TANK 33-5:

* Pump out sludge and clean close tank in place OR

* Remove, haul, and dispose of sludge and tank

- CIP of TPH-CONTAMINATED SOIL by ADMINISTRATIVE CONTROLS: Only administrative activities and associated costs

- EXCAVATION \& DISPOSAL of TPH-CONTAMINATED SOIL

\section{BASIS OF ESTIMATE:}

- Offsite Travel, Feeding and lodging will be provided

- The administrative closure alternative includes:

1) Survey and engineering support will be required for as-built drawing preparation. Site inspection is not anticipated for engineering techs.

2) Implement administrative controls (ie., digging restrictions)

- The tank will be filled with sand, topped out with concrete and cap will be cemented under clean closure in place.

- The utilities (gas, phone, electric, and water lines) will be rerouted accordingly.

- Backfill material for the utilities will be compacted in $8^{\mathrm{N}}$ lifts, 4 passes using a tamper vibrator.

- TPH-contaminated soil will be removed from the site and disposed of at Area 6 Hydrocarbon landfill.

- The foundation of the building will be grouted after removal of the TPH contaminated soil.

- Backfill material will be imported from borrow pit approximately 6 to 7 miles from the site

- A crane will be used to support the tank while disconnecting from the piping and to remove the tanks from the pad.

See following page/s for continuation and cost summary

Review/Concurreng;




\section{Appendix D}

\section{Response to NDEP Comments}




\section{NEVADA ENVIRONMENTAL RESTORATION PROJECT}

\section{DOCUMENT REVIEW SHEET}

(Page 1 of 2)

\begin{tabular}{|c|c|c|c|c|c|}
\hline \multicolumn{4}{|c|}{$\begin{array}{l}\text { 1. Document Title/Number: Draft CADD for CAU 427, Area } 3 \text { Septic Waste Systems } 2 \text { and 6, } \\
\text { Tonopah Test Range }\end{array}$} & \multicolumn{2}{|l|}{ 2. Document Date: April, 1998} \\
\hline \multicolumn{4}{|c|}{ 3. Revision Number: } & \multicolumn{2}{|c|}{ 4. Originator/Organization: IT Corporation } \\
\hline \multicolumn{3}{|c|}{ 5. Responsible DOE/NV ERP Subproject Mgr.: } & & \multicolumn{2}{|l|}{ 6. Date Comments Due: } \\
\hline \multicolumn{6}{|l|}{ 7. Review Criteria: } \\
\hline \multicolumn{3}{|c|}{ 8. Reviewer/Organization/Phone No.: Gregory A. Raab } & & \multicolumn{2}{|l|}{ 9. Reviewer's Signature: } \\
\hline $\begin{array}{l}\text { 10. Comment } \\
\text { Number/ } \\
\text { Location }\end{array}$ & 11. Type* & 12. Comment & \multicolumn{2}{|c|}{ 13. Comment Response } & 14. Accept \\
\hline Page ES-1 of ES-3 & & $\begin{array}{l}\text { According to convention, the individual words are spelled out the } \\
\text { first time the acronym is defined, not afterwards. The last set of } \\
\text { bullets on page ES-1 of ES-3 should read: Prevent mitigate human } \\
\text { exposure... at concentrations greater than } 100 \text { milligrams per } \\
\text { kilogram, Nevada Administrative Code (NAC, } 1996 \text { b). Close Septic } \\
\text { Tank } 33-5 \text { in accordance with NAC } 459 \text {, (NAC 1996c). Prevent... }\end{array}$ & \multicolumn{2}{|c|}{$\begin{array}{l}\text { "(NAC, 1996b)" and "(NAC, 1996c)" are citations of } \\
\text { references and are in accordance with bibliographical rules } \\
\text { for citations in text. }\end{array}$} & No \\
\hline Page 4 of 28 & & $\begin{array}{l}\text { The Appendices need the following corrections: Appendix B: Soil } \\
\text { Core Borings. Appendix C: Cost Estimates }\end{array}$ & \multicolumn{2}{|c|}{$\begin{array}{l}\text { No change to Appendix B title. Modified Appendix } C \text { title as } \\
\text { requested. }\end{array}$} & No \\
\hline $\begin{array}{l}\text { Page } 8 \text { of } 28, \\
1^{\text {st }} \text { paragraph, } \\
1^{\text {st }} \text { sentence }\end{array}$ & & $\begin{array}{l}\text { Although it may be understood by most of the audience reading this } \\
\text { document, it should be stated as to why a septic tank is not closed } \\
\text { by the Department of Human Resources, Health Division } \\
\text { regulations, and falls under a corrective action. Include this } \\
\text { paragraph with the last on the previous page with a simple transition } \\
\text { as follows: As a result of these values exceeding the action levels, } \\
\text { Septic Tank } 33-5 \text { must be closed in accordance with NAC } 459.9921 \\
\ldots \text { inclusive, and therefore does not fall under Department of } \\
\text { Human Resources, Health Division regulations. }\end{array}$ & \multicolumn{2}{|c|}{$\begin{array}{l}\text { Text was modified as follows: } \\
\text { "The samples taken from within Septic Tank } 33-5 \text { indicated } \\
\text { the presence of listed hazardous waste. As a result, Septic } \\
\text { Tank } 33-5 \text { must be closed in accordance with NAC } \\
459.9921 \text {... inclusive, and therefore, does not fall under } \\
\text { Department of Human Resources, Health Division } \\
\text { regulations." }\end{array}$} & Yes \\
\hline $\begin{array}{l}\text { Page } 18 \text { of } 28 \\
4^{\text {th }} \text { paragraph }\end{array}$ & & $\begin{array}{l}\text { The same as above applies: Septic Tank } 33-5 \text { would be closed in } \\
\text { accordance with NAC } 459 \text { (NAC, 1996c) as described in Section } 2.3 \\
\text { and 3.3.2. }\end{array}$ & \multicolumn{2}{|c|}{ Modified text as requested. } & Yes \\
\hline
\end{tabular}




\section{NEVADA ENVIRONMENTAL RESTORATION PROJECT}

DOCUMENT REVIEW SHEET

(Page 2 of 2 )

\begin{tabular}{|c|c|c|c|c|}
\hline $\begin{array}{l}\text { 10. Comment } \\
\text { Number/ } \\
\text { Location }\end{array}$ & 11. Type* & 12. Comment & 13. Comment Response & 14. Accept \\
\hline $\begin{array}{l}\text { Page } A-8 \text { of } A-59, \\
1^{\text {st }} \text { paragraph, } \\
8^{\text {th }} \text { sentence }\end{array}$ & & The term "potholed" should be clarified. & Delete "potholed," insert the word performed. & Yes \\
\hline $\begin{array}{l}\text { Page } A-13 \text { of } A-59, \\
1^{\text {st }} \text { paragraph, } \\
3^{\text {rd }} \text { sentence }\end{array}$ & & $\begin{array}{l}\text { Begins with a } 28 \text { This. It appears to be a typographical error and the } \\
28 \text { should be deleted. }\end{array}$ & Modified text as requested. & Yes \\
\hline $\begin{array}{l}\text { Page } A-28 \text { of } A-59 \text {, } \\
\text { 2nd paragraph }\end{array}$ & & $\begin{array}{l}\text { The fourth and second to the last sentences refer to background } \\
\text { levels. They should be listed here. }\end{array}$ & Modified text as requested. & Yes \\
\hline $\begin{array}{l}\text { Page } A-33 \text { of } A-59, \\
1^{\text {st }} \text { paragraph, } \\
2^{\text {nd }} \text { sentence }\end{array}$ & & $\begin{array}{l}\text { Refers to Potassium- } 40 \text { exceeding background levels. List the } \\
\text { activity for background. }\end{array}$ & Modified text as requested. & Yes \\
\hline $\begin{array}{l}\text { Page } A-33 \text { of } A-59 \text {, } \\
3^{\text {rd }} \text { sentence }\end{array}$ & & $\begin{array}{l}\text { Implies that the leachfield pipes may be a source of the }{ }^{40} \mathrm{~K} \text {. If this is } \\
\text { the case, say so. The human body contains }{ }^{40} \mathrm{~K} \text {, and sheds it with } \\
\text { other natural waste products. }\end{array}$ & $\begin{array}{l}\text { Modified text as follows to remove implication: Delete } \\
\text { "sample locations represent," insert "samples were obtained } \\
\text { from." }\end{array}$ & Yes \\
\hline & & & & \\
\hline & & & & \\
\hline
\end{tabular}

${ }^{a}$ Comment Types: $M=$ Mandatory, $S=$ Suggested

Return Document Review Sheets to DOE/NV Environmental Restoration Division, Attn: QAC, M/S 505. 


\section{Distribution}

*Provide copy on initial distribution of Rev. 0; remainder of list gets Rev. 0 if approved without changes, and entire list receives distribution of Rev. 1, if issued.

Paul J. Liebendorfer

State of Nevada

Bureau of Federal Facilities

Division of Environmental Protection

333 W. Nye Lane, Room 138

Carson City, NV 89706-0851

Donald A. Garrepy

State of Nevada

Bureau of Federal Facilities

Division of Environmental Protection

555 E. Washington, Suite 4300

Las Vegas, NV 89101

Sabrina Bonnell

Environmental Restoration Division

DOE/Nevada Operations Office

P.O. Box 98518, M/S 505

Las Vegas, NV 89193-8518

Janet Appenzeller-Wing

Environmental Restoration Division

DOE/Nevada Operations Office

P.O. Box 98518, M/S 505

Las Vegas, NV 89193-8518

Kevin Cabble

Environmental Restoration Division

DOE/Nevada Operations Office

P.O. Box 98518, M/S 505

Las Vegas, NV 89193-8518

Col. M. Fukey

$99 \mathrm{ABW} / \mathrm{EM}$

4349 Duffer Drive, Suite 1601

Nellis AFB, NV 89191-7007
2 (Controlled)*

1 (Controlled)*

1 (Controlled)*

1 (Uncontrolled)*

1 (Uncontrolled)*

3 (Controlled)* 
Dale Schutte 4680 Bell Vista Avenue

Pahrump, NV 89048

Earl Dixon

CAB Technical Advisor

Harry Reid Center for Environmental Studies 4505 Maryland Parkway

Box 454009

Las Vegas, NV 89154-4009

Technical Information Resource Center

DOE/Nevada Operations Office

P.O. Box 98518, M/S 505

Las Vegas, NV 89193-8518

U.S. Department of Energy

Office of Scientific and Technical Information

P.O. Box 62

Oak Ridge, TN 37831

DOE Public Reading Room

P.O. Box 98521, M/S NLV040

Las Vegas, NV 89193-8521

Jeff Smith

Bechtel Nevada

P.O. Box 98521, M/S NTS306

Las Vegas, NV 89193-8521

Steve Nacht

Bechtel Nevada

P.O. Box 98521, M/S NTS306

Las Vegas, NV 89193-8521

Dustin Wilson

SAIC

P.O. Box 93838

Las Vegas, NV 89193
1 (Uncontrolled)*

1 (Uncontrolled)*

2 (Uncontrolled)

2 (Uncontrolled)

2 (Controlled)*

1 (Uncontrolled)

1 (Uncontrolled)*

1 (Uncontrolled)*

1 (Uncontrolled)* 
Cheryl Rodriguez

HSI GeoTrans

P.O. Box 93838

Las Vegas, NV 89193

IT Corporation Central Files

IT Corporation

P.O. Box 93838

Las Vegas, NV 89193

Rosa Silver

IT Corporation

P.O. Box 93838

Las Vegas, NV 89193

Mary Todd

SAIC

P.O. Box 93838

Las Vegas, NV 89193

Grant Evenson

SAIC

P.O. Box 93838

Las Vegas, NV 89193
1 (Uncontrolled)*

1 (Uncontrolled)*

2 (Controlled)

1 (Uncontrolled)*

1 (Uncontrolled)* 